INTER NATIONAL MONETARY FUND
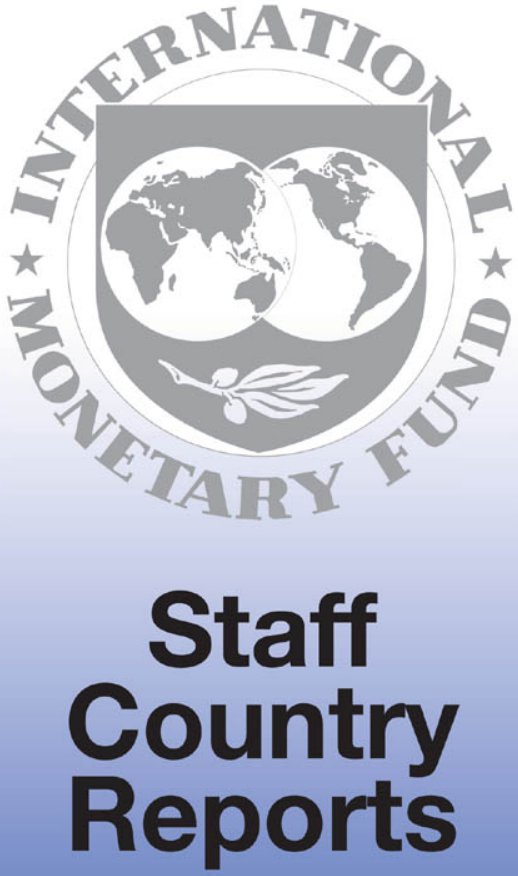


\section{Cape Verde: Recent Economic Developments}

This Recent Economic Developments report on Cape Verde was prepared by a staff team of the International Monetary Fund as background documentation for the periodic consultation with this member country. As such, the views expressed in this document are those of the staff team and do not necessarily reflect the views of the Government of Cape Verde or the Executive Board of the IMF.

\footnotetext{
Copies of this report are available to the public from

International Monetary Fund - Publication Services

700 19th Street, N.W. - Washington, D.C. 20431

Telephone: (202) 623-7430 - Telefax: (202) 623-7201

Telex (RCA): 248331 IMF UR

E-mail: publications@imf.org

Internet: http://www.imf.org
}

Price: $\$ 15.00$ a copy

\section{International Monetary Fund \\ Washington, D.C.}




\section{INTERNATIONAL MONETARY FUND}

\section{CAPE VERDE}

\section{Recent Economic Developments}

Prepared by a staff team consisting of Mr. E. Sacerdoti (Head), Mr. J.-P. Olters, Mr. K. Nassar, Mr. N. Ntungwanayo, and Mr. E. Verreydt (all AFR)

Approved by the African Department

May 10, 1999

Basic Data 4

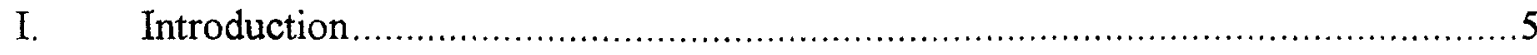

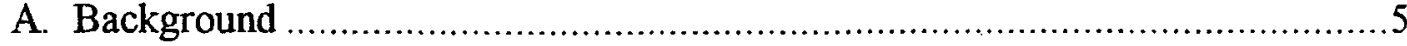

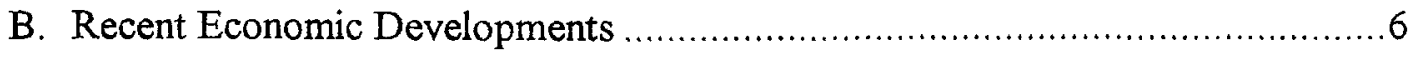

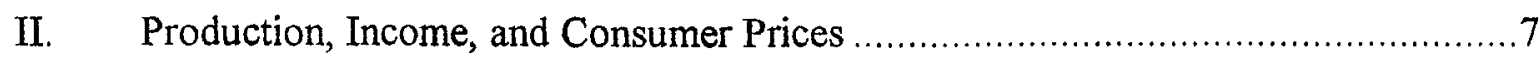

A. Production ..........................................................................................

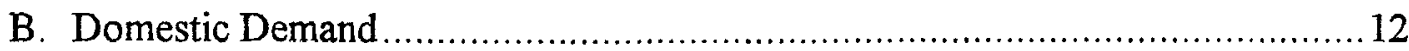

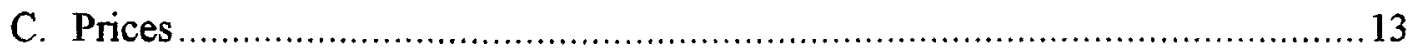

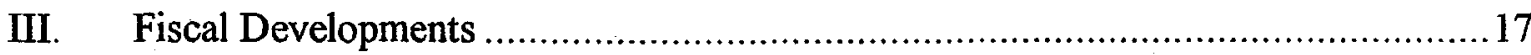

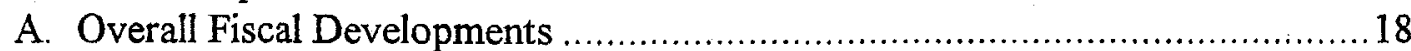

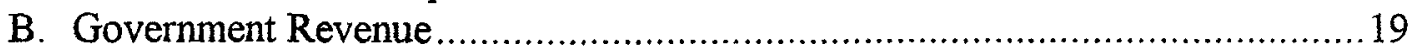

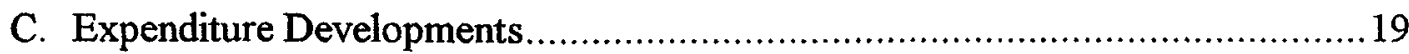

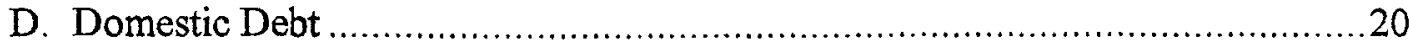

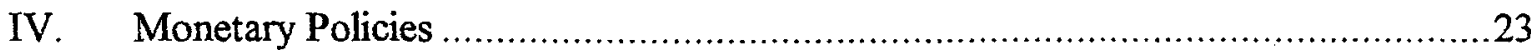

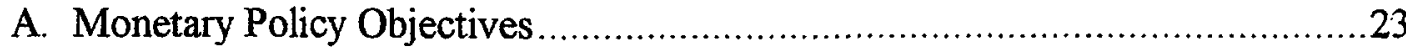

B. Recent Monetary Developments ............................................................24

V. Exchange Rate Policies and External Sector Developments ….........................27

A. Exchange Rate Policies …..................................................................27

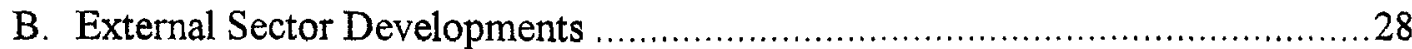

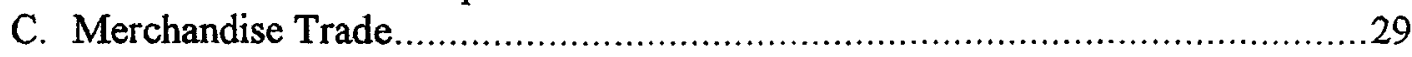

D. Services and Transfers....................................................................29

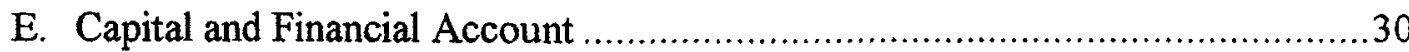

F. External Debt ........................................................................................ 31 


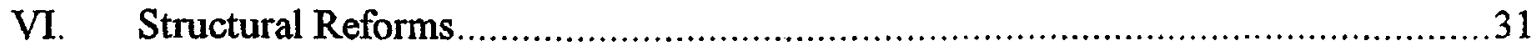

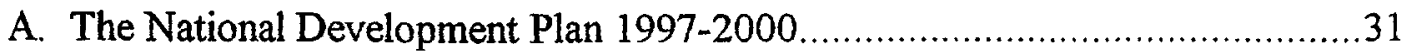

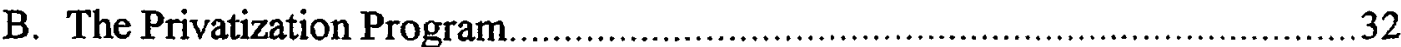

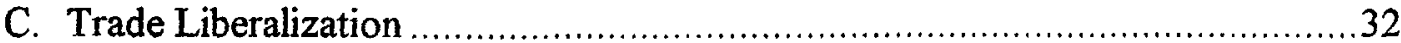

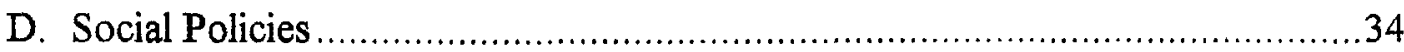

$\underline{\text { Figures }}$

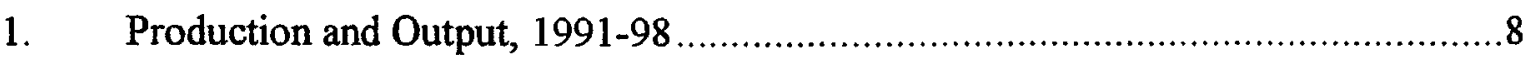

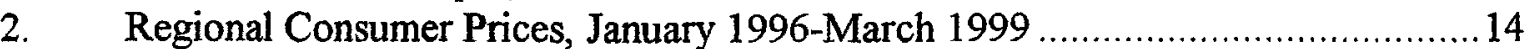

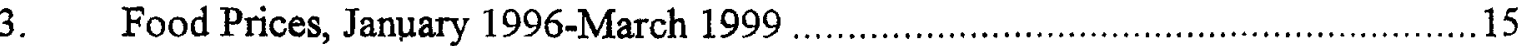

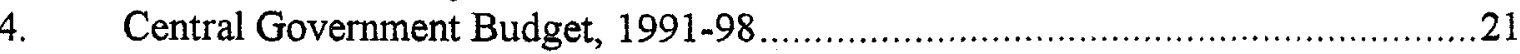

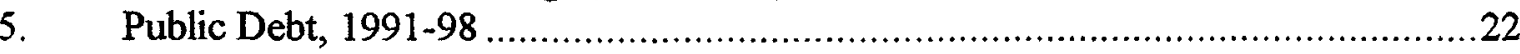

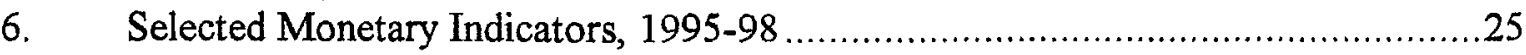

\section{Text Boxes}

1. Improvements in the Compilation of Statistics ..................................... 10

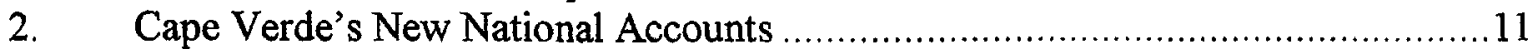

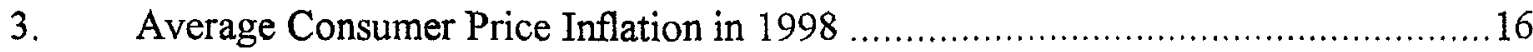

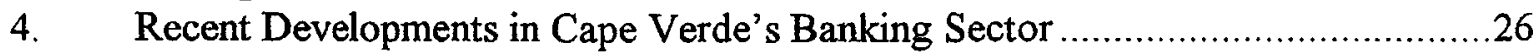

5. Cape Verde's Accelerated Privatization Program 1998-2002 .......................33

Appendix I

Has Cape Verde's Structural Adjustment Program Led to an Increase

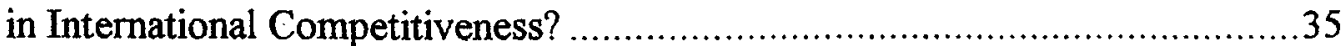

Appendix Tables

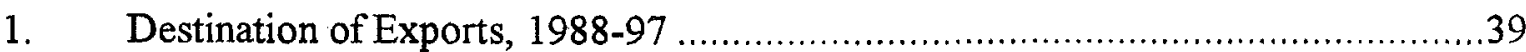

2. Level of Monthly Wages by Occupation, $1990-98 \ldots \ldots \ldots \ldots \ldots \ldots \ldots \ldots \ldots \ldots \ldots \ldots 43$

\section{Appendix Figures}

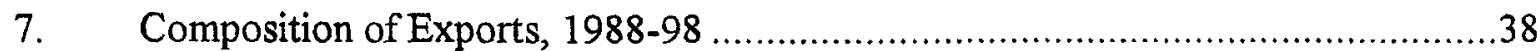

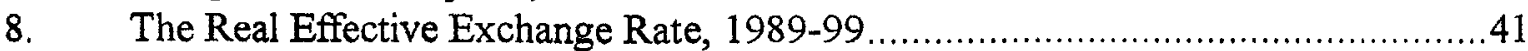

9. Real Annual Wage Increase by Profession, 1991-98 ................................44

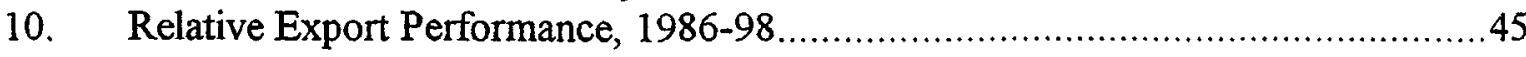


Statistical Appendix Tables

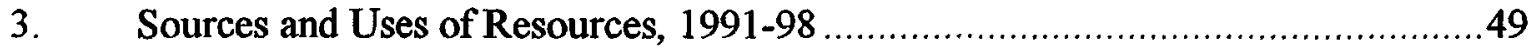

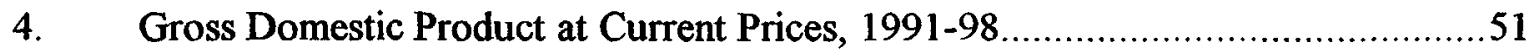

5. Gross Domestic Product at Constant 1980 Prices, 1991-98 _........................52

$6 . \quad$ Production in Agriculture, Livestock, and Fishing, 1994-98 ........................53

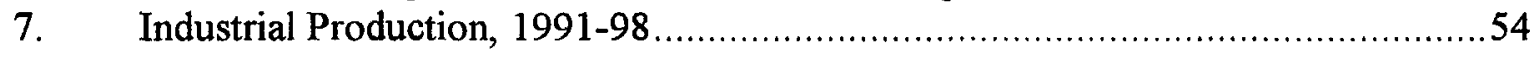

8. Production and Consumption of Electricity and Water, 1991-98 ..................55

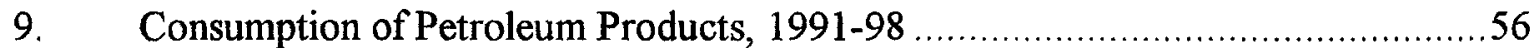

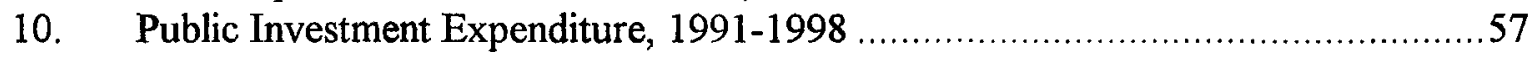

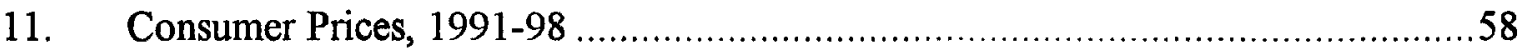

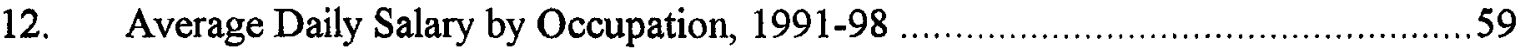

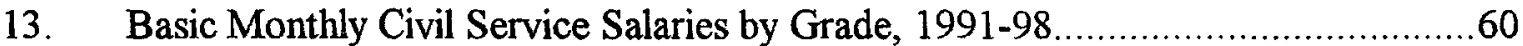

14. Civil Service Employment by Administrative Unit, 1992-98 ........................61

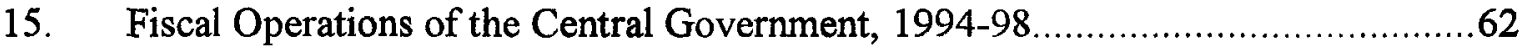

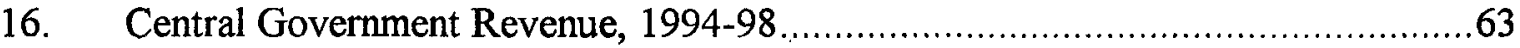

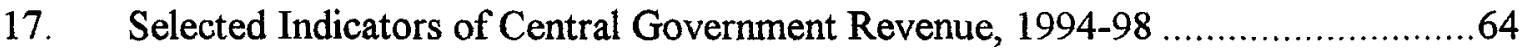

18. Economic Classification of Central Government Expenditure, 1994-98 .............65

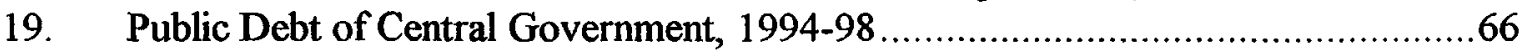

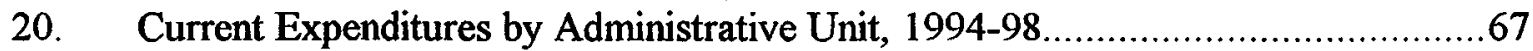

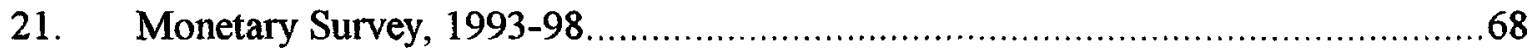

22. Summary Accounts of the Bank of Cape Verde, 1994-98 ..........................69

23. Summary Accounts of the Commercial Banks, 1996-98 ...........................70

24. Summary Accounts of the Banco Comercial do Atlantico, 1996-98 ...............71

25. Summary Accounts of the Caixa Economica de Cabo Verde, 1996-98 ..............72

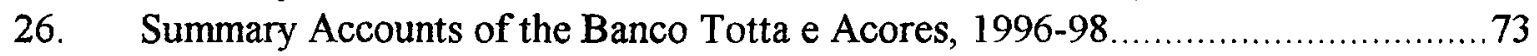

27. Summary Accounts of the Caixa Geral de Depositos, 1996-98 ..................... 74

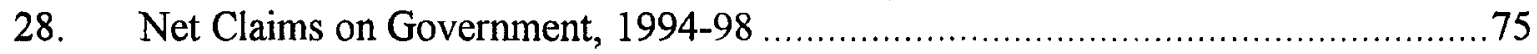

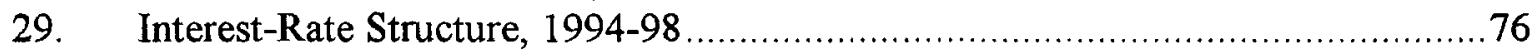

30. Balance of Payments, 1994-98 (In millions of Cape Verde Escudos) ..............77

31. Balance of Payments, 1994-98 (In millions of U.S. Dollars) $\ldots \ldots \ldots \ldots \ldots \ldots \ldots \ldots \ldots \ldots 78$

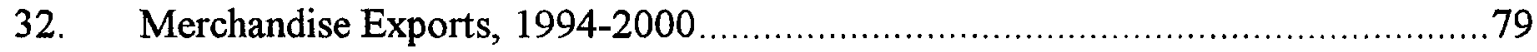

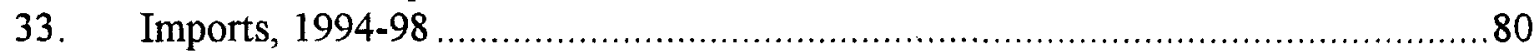

34. Services, $1994-98 \ldots \ldots \ldots \ldots \ldots \ldots \ldots \ldots \ldots \ldots \ldots \ldots \ldots \ldots \ldots \ldots \ldots \ldots \ldots \ldots \ldots \ldots \ldots \ldots . \ldots 1$

$35 . \quad$ Direction of Trade, $1994-98 \ldots \ldots \ldots \ldots \ldots \ldots \ldots \ldots \ldots \ldots \ldots \ldots \ldots \ldots \ldots \ldots \ldots \ldots \ldots 82$

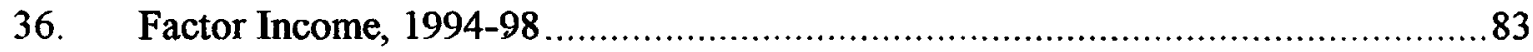

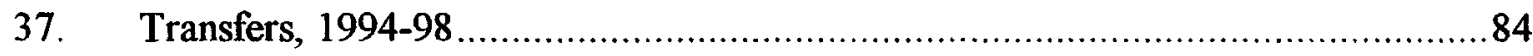

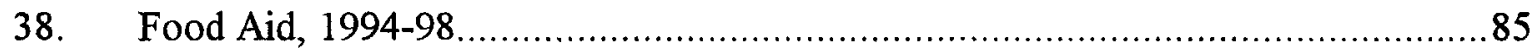

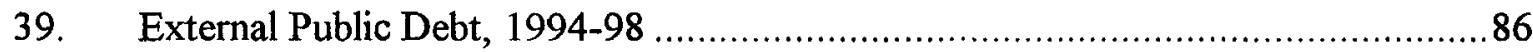

40. External Public Debt by Creditor, $1994-98 \ldots \ldots \ldots \ldots \ldots \ldots \ldots \ldots \ldots \ldots \ldots \ldots \ldots \ldots . \ldots 87$

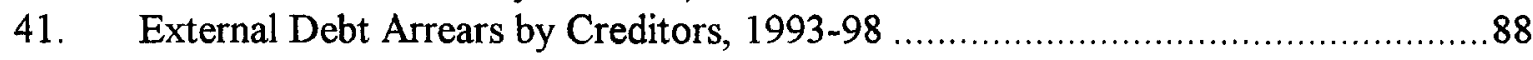

42. Medium-Term Debt-Service Projections on Outstanding

External Debt at End-1998

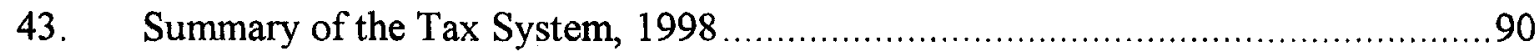


Cape Verde: Basic Data, 1994-98

\begin{tabular}{|c|c|c|c|c|c|}
\hline & 1994 & 1995 & 1996 & 1997 & 1998 \\
\hline Area population and GDP per capita & \multicolumn{5}{|c|}{ (In units indicated) } \\
\hline \multicolumn{6}{|l|}{ Area: 4,036 square kilometers } \\
\hline Population (midycar) (in thousands) $/ /$ & 380 & 390 & 401 & 412 & 423 \\
\hline Population (annual change in percent) l/ & 2.7 & 2.7 & 2.7 & 2.7 & 2.7 \\
\hline GDP per capita (in Cape Verde escudos) $V$ & 88,554 & 97,050 & 101,422 & 109,601 & 115,157 \\
\hline GDP per capita (in U.S. dollars) $1 /$ & $1,081.4$ & $1,262.8$ & 1.228 .0 & $1,176.3$ & $1,172.7$ \\
\hline Gross domestic product and prices & \multicolumn{5}{|c|}{ (Annual changes; unless otherwise specified) } \\
\hline GDP (in millions of U.S. dollars) $1 /$ & 410.8 & 492.7 & 492.0 & 484.0 & 495.6 \\
\hline GDP (in billions of Cape Verde escudos) I/ & 33.6 & 37.9 & 40.6 & 45.1 & 48.7 \\
\hline GDP at current prices i/ & 15.2 & 12.6 & 7.3 & 11.0 & 7.9 \\
\hline GDP at 1980 prices $\mathrm{V} /$ & 6.9 & 7.5 & 3.5 & 5.2 & 5.0 \\
\hline Consumer price index (average) & 3.4 & 8.4 & 6.0 & 8.6 & 4.3 \\
\hline Consumer price index (end of year) & 3.3 & 6.5 & 9.1 & 6.7 & 8.3 \\
\hline National accounts & \multicolumn{5}{|c|}{ (In percent of GDP) } \\
\hline Gross fixed investment & 43.4 & 38.5 & 38.8 & 39.1 & 40.2 \\
\hline Gross domestic savings & 2.8 & -1.3 & 5.9 & 8.4 & 8.3 \\
\hline Gross national savings & 36.2 & 21.7 & 25.9 & 24.9 & 23.5 \\
\hline Contral government finance & \multicolumn{5}{|c|}{ (In percent of GDP) } \\
\hline Total revenue, grants and capital participation & 38.6 & 38.6 & 34.4 & 31.8 & 34.9 \\
\hline Of which: domestic revenue 2 & 23.4 & 23.8 & 21.1 & 21.3 & 24.1 \\
\hline Total expenditure & 52.6 & 51.5 & 48.3 & 42.2 & 39.1 \\
\hline Of which: current expenditure & 20.6 & 24.5 & 22.8 & 23.3 & 22.0 \\
\hline Current balance & 0.5 & -2.3 & -1.7 & -3.9 & 1.9 \\
\hline Primary balance & -28.2 & -24.5 & -23.6 & -16.9 & -11.1 \\
\hline Overal balance, incl. grants (commitment basis) & -14.0 & -12.9 & -13.9 & -10.4 & -4.3 \\
\hline Domestic financing (net) & 9.1 & 9.9 & 9.7 & 9.0 & 0.0 \\
\hline Of which: banking system & 6.3 & 5.2 & 2.4 & 4.8 & 0.0 \\
\hline Extemal financing (net) & 4.9 & 3.0 & 4.3 & 1.4 & 4.3 \\
\hline Money and credit & \multicolumn{5}{|c|}{ (Changes in percent of beginning-of-period money stock) } \\
\hline Net foreign assets & -1.3 & -3.5 & 6.4 & -4.4 & 0.1 \\
\hline Net domestic assets & 17.4 & 24.5 & 1.5 & 16.5 & 1.7 \\
\hline Domestic credit & 21.6 & 22.8 & 8.6 & 17.2 & 5.6 \\
\hline Of which: claims on central government $3 /$ & 29.6 & 9.9 & 9.2 & 6.3 & $-0,9$ \\
\hline Credit to the economy & -11.0 & 13.5 & 2.7 & 11.0 & 5.7 \\
\hline Money and quasi money & 16.3 & 20.6 & 8.9 & 12.1 & 1.8 \\
\hline Of which: Cape Verde escudo money and quasi-money & 16.3 & 20.6 & 8.9 & 12.1 & 1.8 \\
\hline Income velocity of money $4 /$ & 1.6 & 1.5 & 1.5 & 1.5 & 1.6 \\
\hline External sector & \multicolumn{5}{|c|}{ (In percent of GDP; unless otherwise specified) } \\
\hline Real effective exchange rate (annual change in percent) & 5.0 & 2.4 & -0.8 & 5.5 & -4.5 \\
\hline Cape Verde escudos per U.S. dollar (average) & 81.9 & 76.9 & 82.6 & 93.2 & 98.2 \\
\hline Cape Verde escudos per U.S. dollar (end of year) & 81.1 & 77.5 & 85.2 & 96.2 & 94.3 \\
\hline Trade balance (goods and nonfactor services) & -37.6 & -39.8 & -32.8 & -30.7 & -32.0 \\
\hline Current account balance (excluding official transfers) & -18.9 & -16.8 & -12.9 & -14.2 & -15.6 \\
\hline Current account balance (including official transfers) & -9.1 & -16.8 & -12.9 & -14.2 & -15.6 \\
\hline Overal balance of payments & -1.4 & -2.8 & 3.8 & 1.9 & 0]$. \\
\hline Net official reserves (In millions of U.S. dollars) & 41.9 & 66.5 & 55.0 & 46.5 & 35.6 \\
\hline In months of imports of goods and services & 2.3 & 2.7 & 2.4 & 2.0 & 1.5 \\
\hline External debt outstanding & 39.9 & 38.7 & 41.0 & 44.6 & 46.2 \\
\hline Extemal debt services as percent of export of goods and services & 19.5 & 15.5 & 13.6 & 13.9 & 16.0 \\
\hline
\end{tabular}

1/ Estimates of February 1999

2/ Excluding public enterprise transfers

$3 /$ Includes credit to central and local government

4/ Ratio of GDP to broad money stock at end period 


\section{INTRODUCTION}

1. Over the course of the last few years, Cape Verde has pursued an ambitious program of economic liberalization and decentralization, in the context of which the authorities scaled down the state's previously dominant role. Concomitantly, the authorities attempted to preserve and reinforce its social infrastructure and tranquility. While it is too early to conclusively arrive at an assessment of its period of economic transition, recent economic developments seem to indicate that considerable progress has been made in terms of structural adjustment and, more recently, fiscal administration and monetary control.

\section{A. Background}

2. Constrained by an acute scarcity of natural resources, governments in Cape Verde have had to make the development of a sustainable economic base the central plank of their political platforms. Located in the Sahel zone's western tail-end, the arid and drought-ridden archipelago, approximately 650 kilometers off the Senegalese coast, has long been struggling to provide for its population of currently about $400,000{ }^{1}$ Less than one-tenth of Cape Verde's entire area of about 4,030 square kilometers is at all arable-a circumstance that has left the country vitally dependent on the external support provided by its extensive émigré community and international donors. ${ }^{2}$

3. Since independence in 1975, the Cape Verdean authorities have proposed several, very different development strategies. Initially, during the years of Cape Verde's "first republic" (1975-91), the authorities pursued an inward-looking, activist development program, based on central planning and an economically dominant public sector, particularly in areas such as banking, insurance, energy, and transportation. The policy measures, as detailed in previous staff documents, remained relatively prudent, preserved the country's external competitiveness, and, as a result, allowed the economy-bolstered by large foreign transfers - to grow at a solid pace throughout most of the 1980s.

\footnotetext{
${ }^{1}$ Poverty and famine have run like a thread through Cape Verde's 500-year history. Since independence, the governments have made remarkable progress in eradicating famine-in part by relying on labor-intensive public work programs to construct the country's transport and social infrastructure, in part by broadening its traditionally narrow productive base. The real sector's rapid growth rates notwithstanding, the economy has not yet managed to generate sufficient employment for its people. As a result, poverty-particularly among women, the unskilled, and untrained-continues to be a widespread phenomenon of Cape Verdean society. According to recent World Bank studies, approximately one-third of the population is poor, one-seventh very poor. The large majority of the poverty-stricken families live in rural areas, thereby exacerbating the effects of droughts and other climatic and environmental adversities.

${ }^{2}$ It has been estimated that roughly twice as many expatriates live in the United States, Portugal, and other countries-mainly in Western Europe and Africa-than on the islands.
} 
4. Steady emigration relieved the demographic pressures of high population growth ${ }^{3}$ and allowed per capita income to grow steadily, securing Cape Verde's position as a "lowermiddle-income country." Unemployment, however, remained high. By the late 1980s, key macroeconomic variables had started to deteriorate rapidly, indicating the ultimate unsustainability of the interventionist development program. With an ensuing drop in aid and remittances, the government needed-but ultimately failed-to cut its expenditure substantially in order to regain its macroeconomic balance. Instead, it relied on domestic bank credit to cover the increasing fiscal deficit, which, in turn, led to heightened financial pressures that exacerbated the effects of the economic contraction already slowing down real sector activities. Consequently, unemployment and inflation rose, while official reserves dwindled and arrears on external debt service accumulated.

5. By 1988, the government had begun to reorient its development strategy by introducing measures that were aimed at-albeit hesitantly-liberalizing prices and trade and at fostering private sector activities. The economic reform process gathered further momentum when the political landscape was transformed concurrently. Throughout the first one-and-a-half decades of Cape Verde's postcolonial history, the tight control over economic activities had been complemented by an equivalent degree of political monopoly exerted by the Partido Africano da Indepedência (PAIGC; since 1981, PAICV). Following the country's first multiparty elections (held in 1991), which signified the beginning of Cape Verde's "second republic," the PAICV was ousted and replaced by the market-oriented Movimento para a Democracia (MpD).

\section{B. Recent Economic Developments}

6. Under a new constitution, which was ratified in 1992, and with further electoral successes in 1995-96, the MpD-led government has been setting in motion a comprehensive structural adjustment program aimed at broadening the economy's production base, but this time through the use of market instruments. With these policies, as outlined in the national development plan, the government sought to diversify Cape Verde's economy, restore its macroeconomic and financial balances, reduce the relative size of the public sector, and control the domestic debt situation in order to encourage the development of a dynamic private sector, the creation of jobs, and the building of a social infrastructure. The transformation of Cape Verde's political and economic landscape has received support from the international donor community.

7. While-in the wake of the country's comprehensive adjustment program (launched in 1992) - the GDP growth rates accelerated again, unemployment remained at the high level of about 25 percent and fiscal policies, until 1996, unsustainably lax. This situation resulted in the rapid accumulation of domestic debt and the depletion of foreign reserves to a level as low as half a month of imports in early 1996 (Figures 4 and 6). Temporarily imposing import quotas, the government began to tighten fiscal policies and sought donor support for a

\footnotetext{
${ }^{3}$ Between 1990 and 1995, Cape Verde's population grew at a rate of 2.3 percent a year, with a fertility rate equal to an average of four children born to every woman.
} 
multilaterally coordinated domestic debt-reduction operation. In 1998, it negotiated a precautionary Stand-By Arrangement with the Fund in support of its economic and financial policies.

\section{Production, Income, AND Consumer Prices}

8. According to revised national account estimations, economic activity during the country's transition period appears to have been more dynamic than previously believed, particularly in the primary and tertiary sectors. Largely as a result of fiscal contraction and droughts, growth rates of real GDP during the 1996-98 seem to have slowed down to some extent. Real per-capita GDP, however, has grown consistently throughout the entire transition period, as has the ratio of private sector activity to overall output. Inflationary pressures that existed in 1996 and 1997 have, for the most part, receded in 1998.

\section{A. Production}

9. Throughout the period of structural adjustment (1992-98), real GDP in Cape Verde has grown at rates considerably higher than previously calculated-an average $51 / 2$ instead of 4 percent; see Box 1. This became apparent in 1998, after the National Institute of Statistics (INE) refined the method of calculating the country's national-account estimates, which it published for the period 1992-95, together estimates for 1996-97 and preliminary ones for 1998 (Tables 4 and 5). According to the provisional calculations, real GDP-despite failing rains on several islands-grew by around 5 percent in 1998, a figure that is broadly in line with the revised average of annual growth rate for the transition period. ${ }^{4}$

10. The rapid expansion of economic activity has been fuelled by a number of factors, including (1) the development of tourism facilities, (2) rising foreign investment, especially in export-oriented manufacturing, and (3) an increase in the receipts of workers' remittances, which have stimulated construction. This dynamism is also reflected in the accelerating net

\footnotetext{
${ }^{4}$ The difference in the GDP estimations largely stems from new economic activities, which had not been taken into account in the previous calculations. INE's staff emphasized that the provisional figures (1996-97) - compiled for the very first time in Cape Verde-might understate actual GDP growth, because the economic activities in "non-traditional" sectors may not have yet been fully considered. Only the substantiated official figures will show whether statistical problems of estimation and projection are indeed an important factor, which could help to explain the slowdown of average growth rates from 6.4 percent for the years with final national accounts (1992-95) to an average figure of 4.4 percent for the following two-year period. Revised real GDP estimates were estimated by retroactively combining the nominal sectoral figures with the corresponding price movements in order to recalculate the GDP at constant 1980 prices. The process is ongoing, and the final nominal GDP figures for 1996 and 1997, together with the corresponding figures in real terms, are expected to be published shortly.
} 
Figure 1. Cape Verde: Production and Output, 1991-98

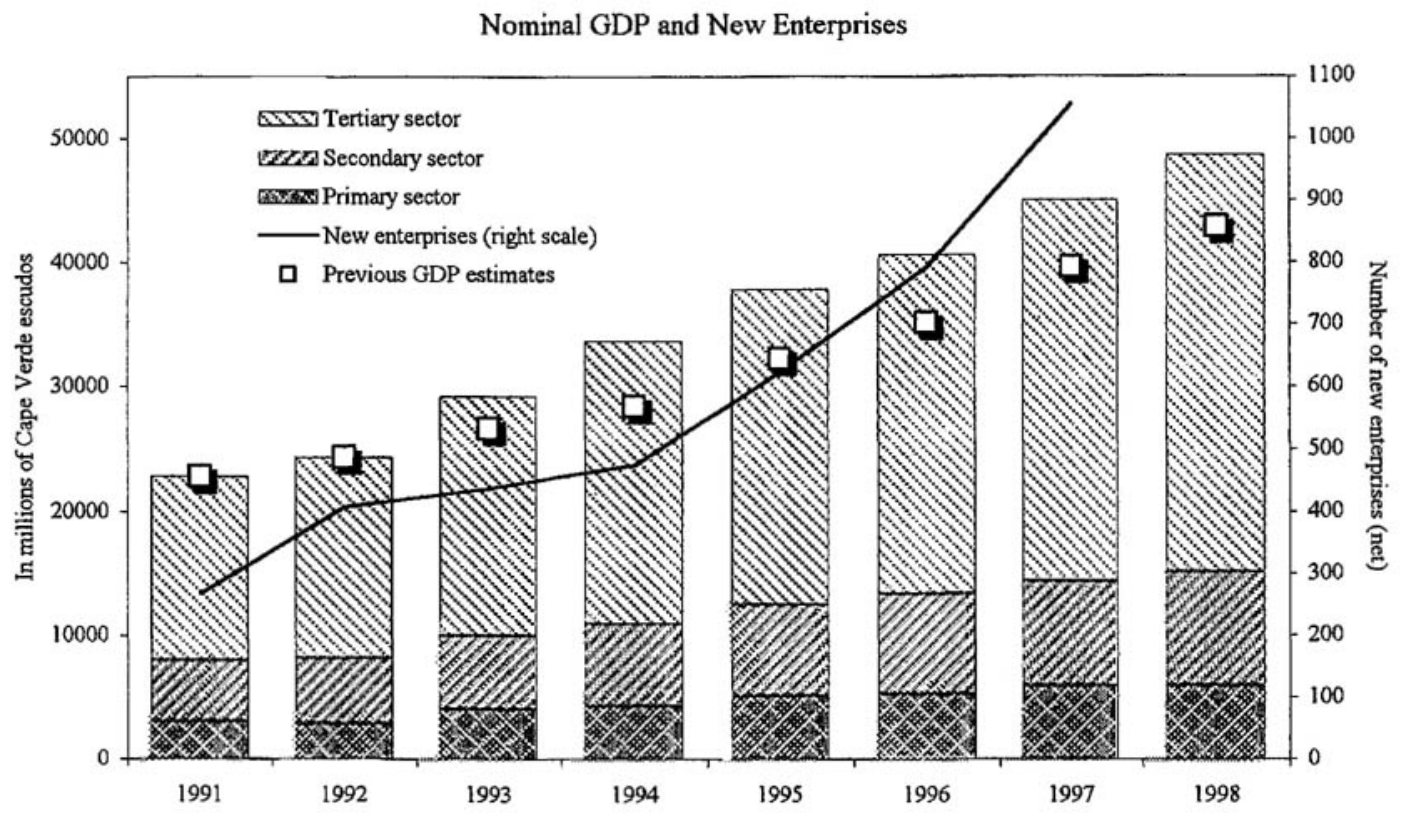

Use of Resources

Selected External Indicators
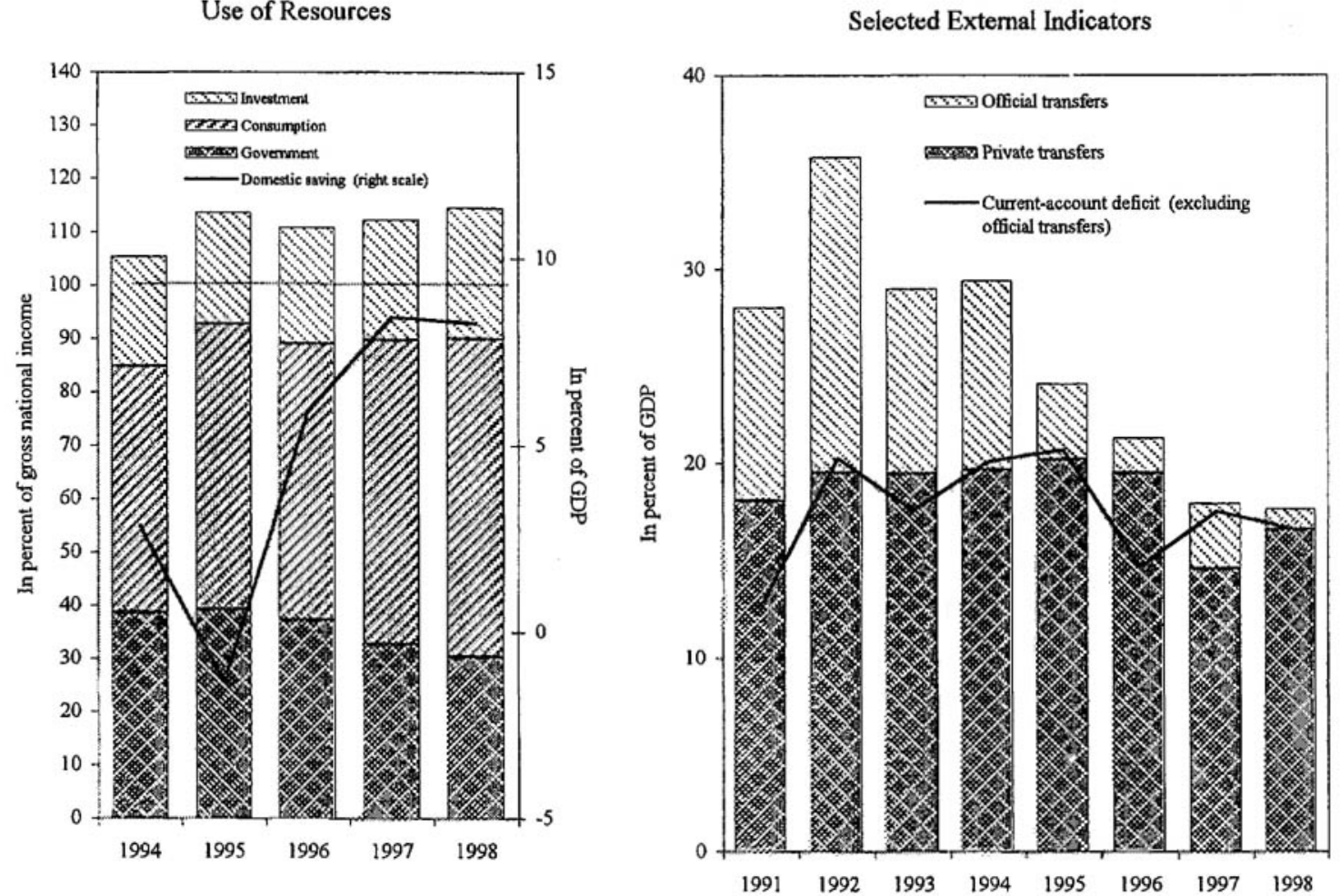

Sources: National Institute of Statistics; Bank of Cape Verde; and staff estimates 
rate of business creation in Cape Verde throughout the transition period-also shown in the accompanying Figure 1.

11. The detailed analysis of the differences with the previous and revised national accounts for 1995 (in constant 1980 prices)-the last official estimates that have been published by INE so far-reveals that the main changes in the structure of the economy were found in banking (which sector has grown 147 percent faster than earlier calculations had predicted), transport and communications (34 percent), and hotels (30 percent); see Box 2 . These variances highlight the crucial importance of the tertiary sector in the process of expanding the country's productive base, but also hints at considerable average growth rates in agriculture and fishing.

12. These results are reinforced when analysing the nominal ${ }^{5}$ estimates for the $1996-98$ period (Table 4), which, inter alia, show that the value of services provided by hotels has more than doubled in 1997, from which level the sector continued to grow in 1998. The banking and the transport and communication sectors as well continued to expand rapidly, with almost consistent above-average growth rates during the 1993-98 period. ${ }^{6}$ The large variability in primary sector data, by contrast, reveals the degree, to which climatic factorssuch as the droughts of 1996 and 1998 or the effects of el Niño (1997) and la Niña (1998) on mid-Atlantic water temperatures-affected the outcomes in both agriculture and fishing, notwithstanding the considerable productivity advances achieved in both sectors.

13. Throughout the entire transition period 1992-98, real GDP has increased at rates that exceeded population growth The dynamism, however, seems to have lost some pace in 1996 (see figure to the right). The deceleration of growth was largely due to the government's response to the balance-of-payment difficulties described in paragraph 7 . The subsequently pursued policies of fiscal contraction, combined with the introduction of import restrictions (which were imposed as an interim measure),

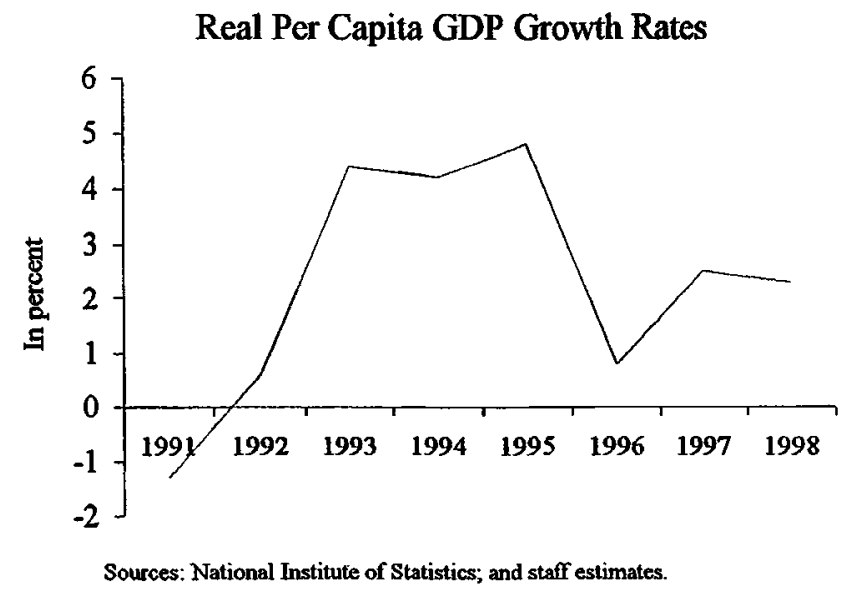

\footnotetext{
${ }^{5}$ No corresponding real figures exist for these years, but efforts at compiling and reconciling real sector data are ongoing, as, for instance, reflected in the incompleteness of Tables 6-9.

${ }^{6}$ The opening of branches by two foreign banks partly explain the high growth rates in the banking sector (see Chapter IV, Section B and Box 4), whereas the development in the transport and communication sector is closely correlated with the expansion of tourism in Cape Verde.
} 


\section{Box 1. Improvements in the Compilation of Statistics}

Strengthening of the statistical institute. Responding to the assessment of an IMF statistics mission in 1996, according to which the compilation of statistics was hindered by both severe resource constraints and an obsolete legal framework, the Cape Verdean parliament adopted a new statistics law in 1996 that addressed most of the problem areas. The statistical agenda is now being set by the newly established National Statistics Council, which is comprises both public and private sector representatives. Moreover, the law establishes clear requirements for the timely communication of data to the National Institute of Statistics (INE), while equipping the institute with legal instruments designed to ensure that both public and private entities meet their commitments.

Survey of enterprises. In order to correct the deficiencies of the statistical system, particularly in respect to the national accounts, which had not taken into account the changes to the economy caused by the structural adjustment program launched in 1992, the INE staff undertook a comprehensive statistical survey of enterprises in 1998, concentrating on areas such as the creation of producer price indices and sound employment data, with a view to capturing the substantial structural changes that have occurred throughout the country's transition period. The enterprise survey was one pivotal pillar in compiling the national account estimates for Cape Verde's transition years.

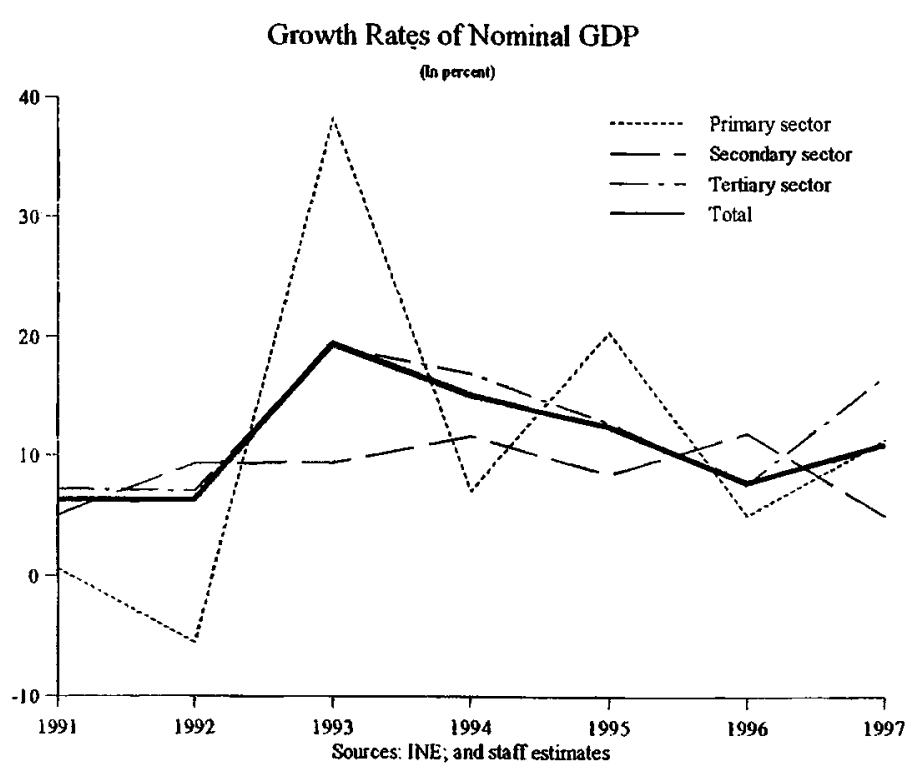

Revised national accounts. In 1998, INE published official figures for the country's 1993-95 national accounts and preliminary ones for $1996-97$. With this effort, it is expected that the backlog in the preparation of national accounts will soon be eliminated. The accompanying figure, representing the revised nominal growth rates of the three sectors, underlines the particular - and steadily increasing - importance of the tertiary sector, which grew at an average rate of 12.5 percent during the 1991-97 period-compared with 11.1 percent for the primary sector, 8.6 percent for the secondary sector, and $\mathbf{1 1 . 2}$ percent for overall nominal GDP. 
Box 2. Cape Verde's New National Accounts, 1993-97

\begin{tabular}{|c|c|c|c|c|c|c|c|c|c|c|}
\hline & \multicolumn{2}{|c|}{1993} & \multicolumn{2}{|c|}{1994} & \multicolumn{2}{|c|}{1995} & \multicolumn{2}{|c|}{1996} & \multicolumn{2}{|c|}{1997} \\
\hline & Previous & Revised & Previous & Revised & Previous & Revised & Previous & Revised 1/ & Previous & Revised 1/ \\
\hline & \multicolumn{10}{|c|}{ (In millions of Cape Verde escudos; unless otherwise specified) } \\
\hline GDP (current prices) & 26,627 & 29,215 & 28,441 & 33,641 & 32,229 & 37,864 & 35,147 & 40,638 & 39,650 & 45,101 \\
\hline Annual growth rates (in percent) & 9.3 & 20.0 & 6.8 & 15.2 & 13.3 & 12.6 & 9.1 & 7.3 & 12.8 & 11.0 \\
\hline Agriculture, forestry and livestock & 2,552 & 3,462 & 2,159 & 3,646 & 2,374 & 4,469 & 2,625 & 4,547 & 2,946 & 5,160 \\
\hline Fishing & 395 & 545 & 426 & 645 & 488 & 663 & 424 & 735 & 482 & 736 \\
\hline Industry and energy & 2,651 & 2,699 & 3,058 & 3,049 & 3,468 & 3,585 & 2,573 & 4,173 & 2,900 & 4,444 \\
\hline Construction & 3,175 & 3,165 & 3,425 & 3,476 & 3,919 & 3,566 & 4,926 & 3,825 & 5,578 & 3,938 \\
\hline Commerce & 4,560 & 4,446 & 5,015 & 5,429 & 5,766 & 6,074 & 7,463 & 6,363 & 8,393 & 6,975 \\
\hline Hotels & 342 & 423 & 325 & 455 & 358 & 456 & 374 & 625 & 433 & 1,464 \\
\hline Transport and communications & 4,727 & 5,162 & 5,024 & 6,292 & 5,681 & 6,363 & 5,525 & 6,839 & 6,456 & 7,589 \\
\hline Banks and insurance & 341 & 755 & 369 & 747 & 419 & 1,394 & 466 & 1,774 & 535 & 2,414 \\
\hline Housing & 2,082 & 1,939 & 2,252 & 2,087 & 2,483 & 2,431 & 2,755 & 2,527 & 3,159 & 2,896 \\
\hline Public services & 3,505 & 4,100 & 3,792 & 4,685 & 4,284 & 5,412 & 4.648 & 5,473 & 4,973 & 6,264 \\
\hline Other services & 2,297 & 2,405 & 2,596 & 2,991 & 2,989 & 3,280 & 3,368 & 3,569 & 3,795 & 2.960 \\
\hline New sectors & $\ldots$ & 115 & $\ldots$ & 138 & $\ldots$ & 171 & $\ldots$ & 190 & $\ldots$ & 261 \\
\hline GDP (constant 1980 prices) & 10,389 & 10,681 & 10,783 & 11,422 & 11,298 & 12,278 & 11,634 & 12,707 & 11,982 & 13,368 \\
\hline Annual growth rates (in percent) & 4.1 & 7.1 & 3.8 & 6.9 & 4.8 & 7.5 & 3.0 & 3.5 & 3.0 & 5.2 \\
\hline Agriculture, forestry and livestock & 1,006 & 1,079 & 832 & 1,014 & 915 & 1,077 & 869 & $\ldots$ & 891 & $\ldots$ \\
\hline Fishing & 102 & 125 & 107 & 151 & 112 & 165. & 140 & $\ldots$ & 146 & $\ldots$ \\
\hline Industry, energy & 709 & 518 & 795 & 558 & 827 & 673 & 852 & $\ldots$ & 877 & $\ldots$ \\
\hline Construction & 1,432 & 1,458 & 1,502 & 1,486 & 1,576 & 1,541 & 1,631 & $\ldots$ & 1,688 & $\ldots$ \\
\hline Commerce & 2,194 & 2,113 & 2,345 & 2,258 & 2,473 & 2,460 & 2,470 & $\ldots$ & 2,540 & $\ldots$ \\
\hline Hotels & 125 & 160 & .116 & 169 & 117 & 152 & 124 & $\ldots$ & 131 & $\ldots$ \\
\hline Transport and communications & 1,566 & 1,890 & 1,618 & 2,185 & 1,678 & 2,241 & 1,829 & $\ldots$ & 1,939 & $\ldots$ \\
\hline Banks and insurance & 134 & 207 & 140 & 202 & 147 & 362 & 154 & $\ldots$ & 162 & $\ldots$ \\
\hline Housing & 815 & 821 & 855 & 852 & 870 & 898 & 912 & $\ldots$ & 956 & $\ldots$ \\
\hline Public services & 1,372 & 1,511 & 1,439 & 1,513 & 1,502 & 1,670 & 1,538 & $\cdots$ & 1,505 & $\ldots$ \\
\hline Other services & 933 & 801 & 1.035 & 1,034 & 1,082 & 1,039 & 1,115 & $\ldots$ & 1,148 & $\ldots$ \\
\hline New sectors & $\ldots$ & $\ldots$ & $\ldots$ & $\ldots$ & $\ldots$ & $\ldots$ & $\ldots$ & ... & $\ldots$ & $\ldots$ \\
\hline
\end{tabular}

Sources: National Institute of Statistics; and staff estimates.

1/ The GDP figures for 1996-97 are preliminary estimates. 
noticeably suppressed aggregate demand, while failing rains damaged agricultural production. ${ }^{7}$ This development was short-lived, as output growth accelerated again in 1997 , largely as a result of increasing travel receipts-the number of tourists rose by 27 percentand, following normal precipitation, a rejuvenated agricultural sector. In addition, the government's emergency contraction was partially loosened; wage expenditures, for instance, increased by 12 percent and thus considerably faster than prices. The combination of an outward shift in aggregate demand and higher wages led not only to the solid growth rates in 1997 but also higher inflation. The year1998 saw a comparably dynamic increase in output (but without the inflationary side effects), largely caused by a continuously buoyant tourism sector and a remittances-led boom in residential construction.

\section{B. Domestic Demand}

14. In recent years, the government has made significant progress in reaching several important of the underlying goals set out its comprehensive adjustment program-viz., the widening of the country's productive base and the encouragement of private sector activities. Accordingly, the government further limited its involvement in the economy, as depicted in the accompanying Figure 1 encapsulating the depth of the structural changes that have occurred in the Cape Verdean economy: government activities, which still consumed about 39 percent of gross national income (or 48 percent of GDP) in 1995, steadily decreased in relative importance to an estimated 30 percent of gross national income (or 35 percent of GDP) in 1998 (see Table 3).

15. In contrast, private sector investments (particularly in light industry, tourism, fisheries, maritime transportation, telecommunications, and construction) have increased from a level of 26 percent of GDP maintained throughout the 1995-97 period to more than 28 percent in 1998 . Firms have responded favorably to specific tax incentives (particularly generous in the export-processing zones ${ }^{8}$ ), the full liberalization of current account transaction (Chapter V, Section A), as well as the overall economic program of modernization and decentralization.

16. Domestic savings as well have increased noticeably-from dissavings equivalent to 1.3 percent of GDP in 1995 to a positive figure of 8.3 percent in 1998 . The public investment program, relative to output, remained at a relatively constant level of 12-13 percent during 1995-98. ${ }^{9}$ Reflecting the relatively reduced importance of the public sector, both

${ }^{7}$ In real terms, recurrent expenditure decreased by 5.5 percent in 1996, while it increased again-by about 5 percent - in 1997. Due to a contraction in capital expenditure, overall expenditure, however, continued to be reduced, in real terms, by 5.3 percent in 1996 and 11.7 percent in 1997; see Chapter III, Section C and Tables 11 and 15.

${ }^{8}$ These include temporary exemptions from corporate taxation on profits and dividends and duty-free imports of equipment and materials used in the production process.

${ }^{9} \mathrm{INE}$ 's public expenditure figure includes municipalities as well, thus resulting in a higher overall figure than the one used in the fiscal section; see Table 10. The institute's economic continued 
consumption and the trade deficit showed a significant trend increase in the relative use of resources in Cape Verde; see Table 3.

\section{Prices}

17. Inflation in Cape Verde - notwithstanding the 6 percent devaluation of the escudo vis-à-vis a currency basket in end-March 1998-continued to decline in 1998, to an average 4.3 percent, half the rate of 1997 (Table 11). The analysis of the 12-month changes in the price level, however, reveals an increase at year's end-owing, in part, to the effects of the altered parity. The fourth-quarter rates were also affected by the autumn drought, which led to significantly higher food prices in Praia and the rural areas during late 1998 (Figure 3). Judging from the money supply growth data (see, for instance, Figure 6), as well as the consumer price index for the first three months of 1999, the downward trend in inflationwhich has largely been the result of improved fiscal and monetary discipline-appears to be continuing, with Cape Verde's consumer price increases showing signs of converging with the ones prevailing in the euro zone, to which currency the escudo has been pegged since the beginning of 1999.

18. Inflation rates in Cape Verde have tended to vary widely across products (Box 3 ) and regions. While the price level in the capital Praia has long been consistently higher than in the rest of the country-between 1996 and 1998, Praia's CPI was, on average, about 4.7 percent above the national oneDifference in Price Levels consumer prices in São Vicente tended to increase more modestly ${ }^{10}$ and thus remained at a lower level. Goods and services on this northern island, on which the country's main port Mindelo is located, were-compared to the country as a whole-discounted by about 4.2 percent (see also figure to the right). It is interesting to note that, throughout the 1996-98 period, the price level differences between urban and rural Cape Verde Compared with National Average shifted relatively significantly-the cities

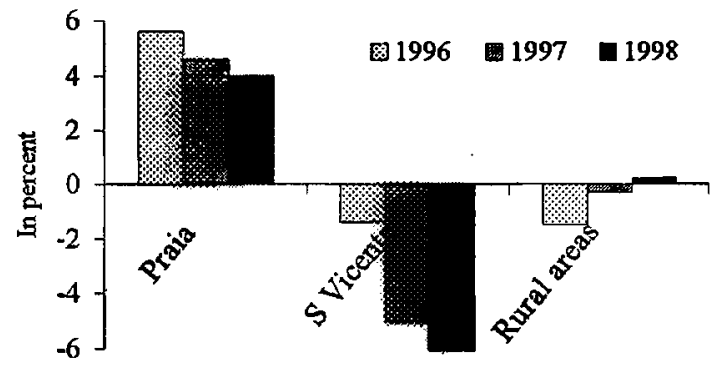

Sources: National Institute of Statistics; and staff estimates.

definition of "public investment" is narrower than the budgetary used by the treasury. According to INE's more comprehensive classification, public investment expenditures steadily declined during the $1994-98$ period, falling from 32 percent to $27,26,19$, and 17 percent of GDP.

${ }^{10}$ The average monthly inflation rate in São Vicente during the January 1996-December 1998 period was 0.4 percent-substantially lower than the corresponding 0.7 percent increases seen in both Praia and the rural areas. 
Figure 2. Cape Verde: Regional Consumer Prices, January 1996 - March 1999

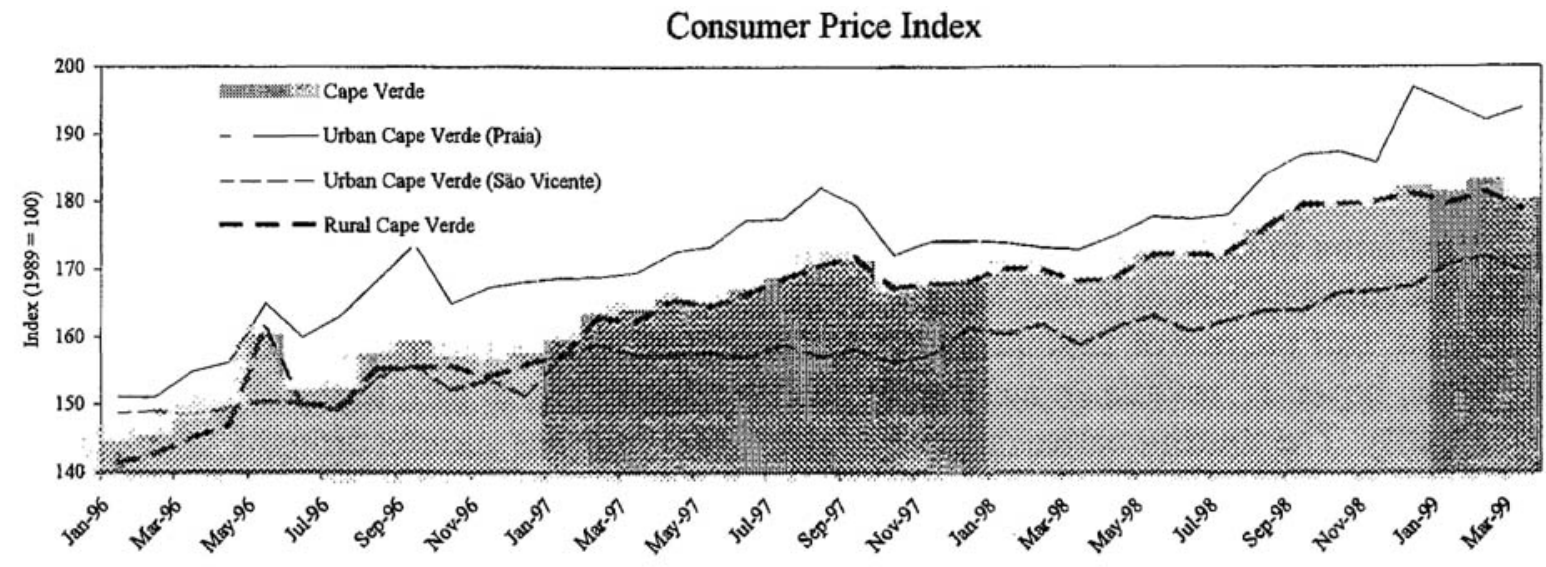

Twelve-Month Inflation Rates

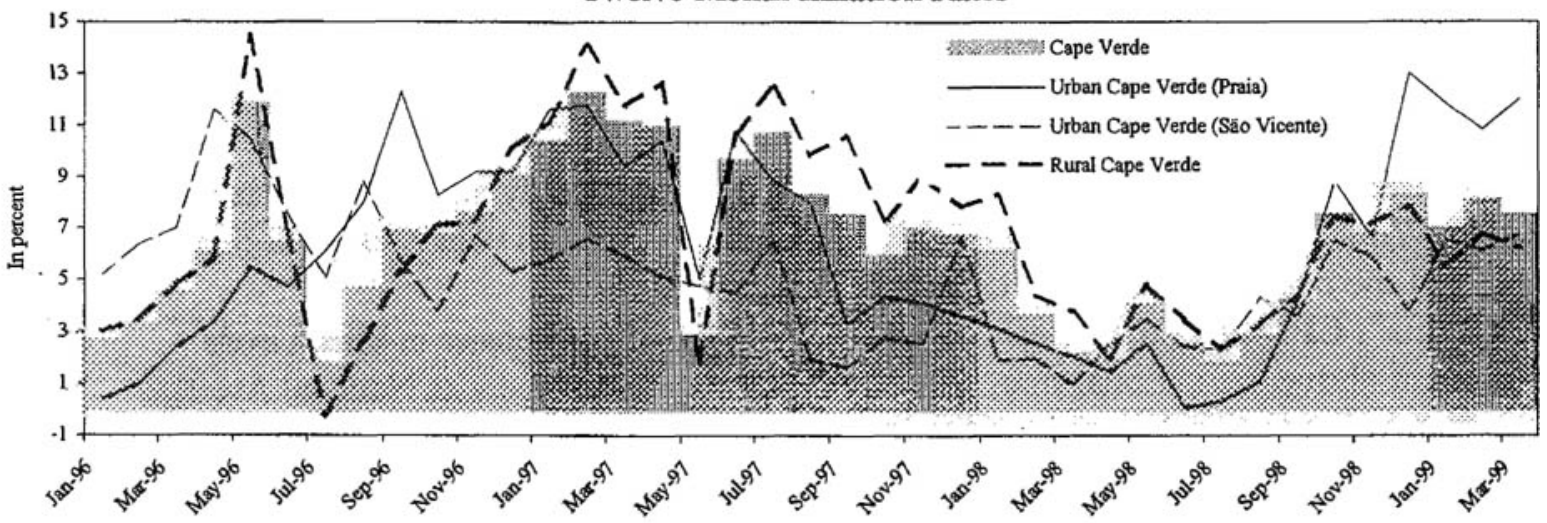

Monthly Inflation Rates

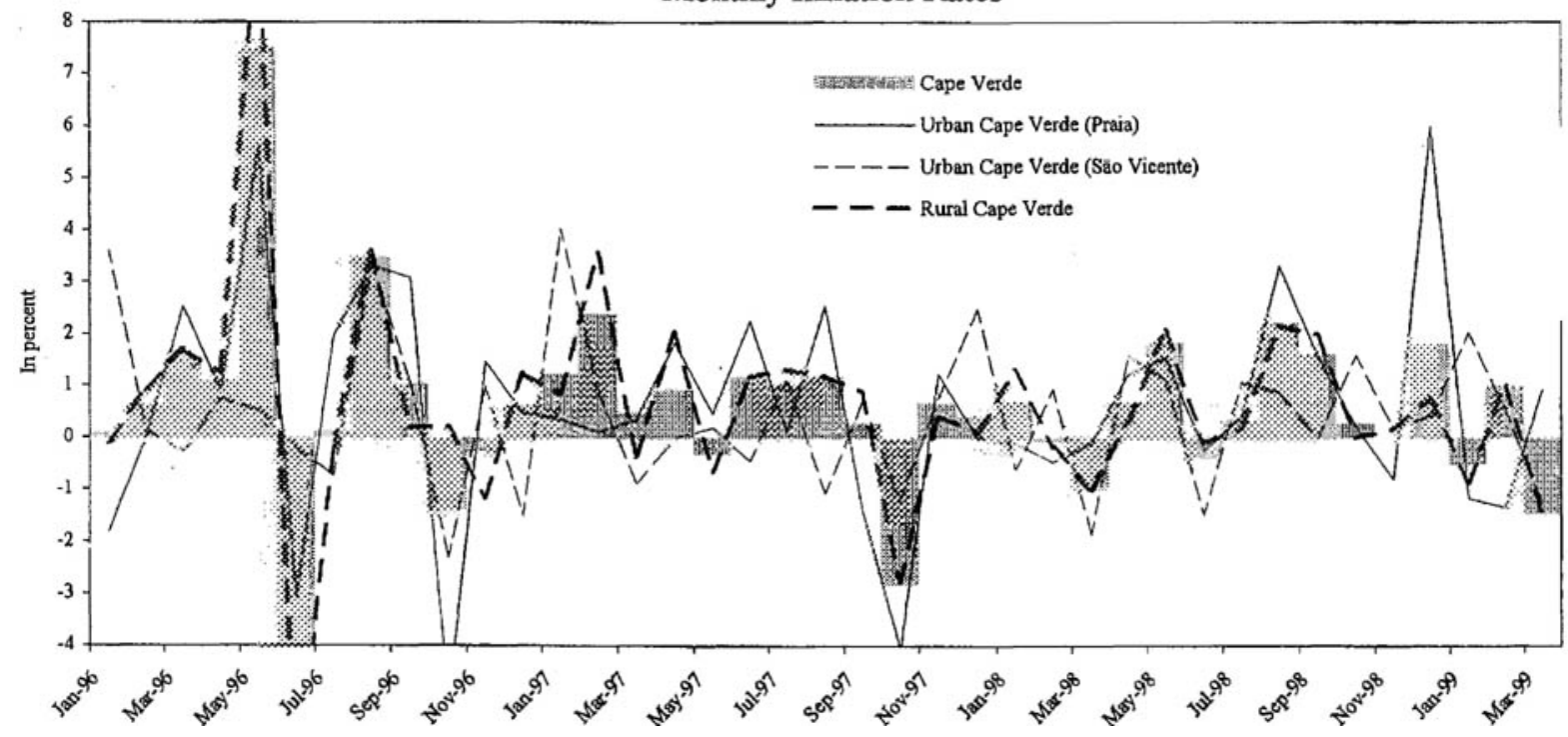

Sources: National Institute of Statistics; and staff estimates. 
Figure 3. Cape Verde: Food Prices, January 1996 - March 1999

Food-Price Index

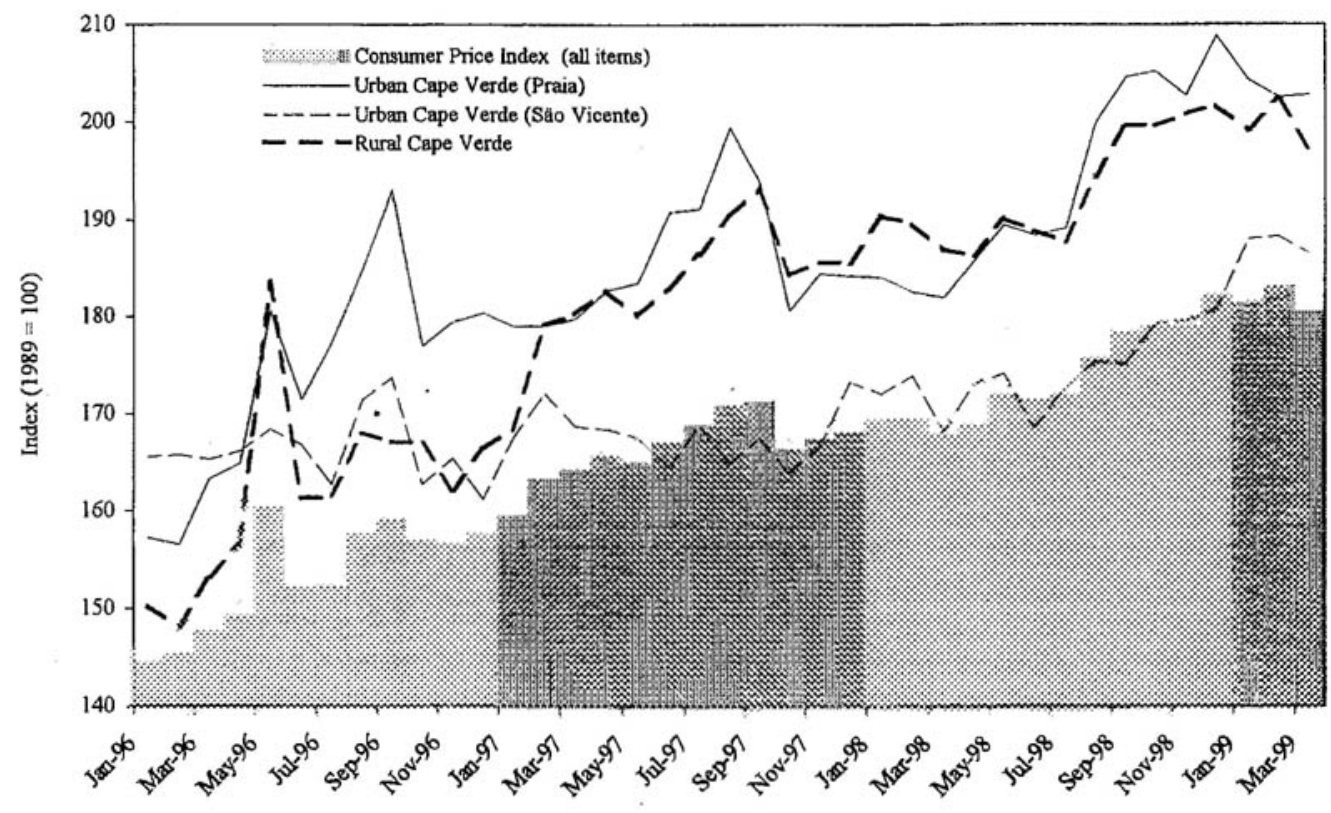

Twelve-Month Food Price Inflation

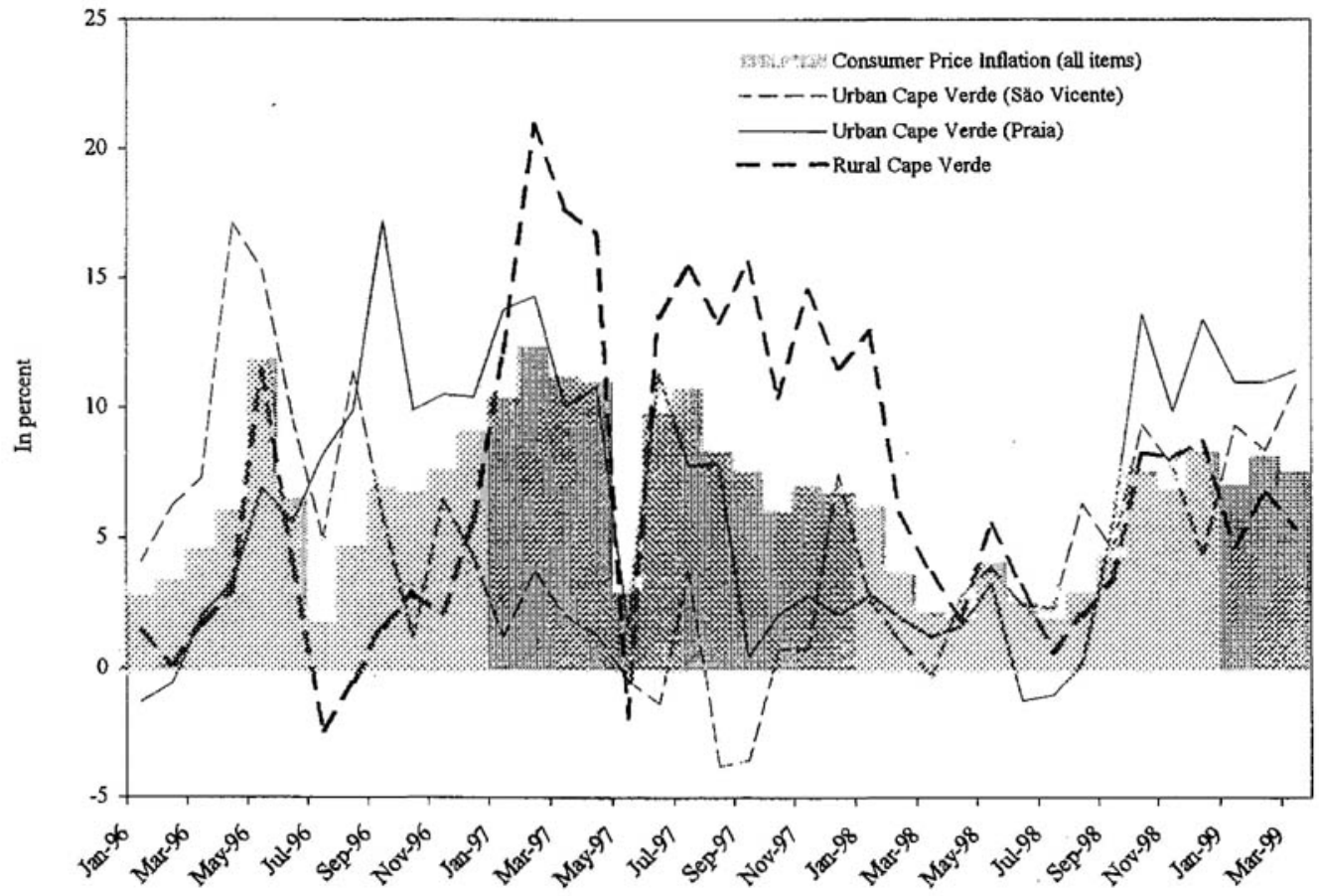

Sources: National Institute of Statistc; and staff estimates. 
Box 3. Cape Verde: Average Consumer Price Inflation in 1998 (In percent)

\begin{tabular}{lrrrr}
\hline & Praia & Säo Vicente & Rural Areas & Cape Verde \\
& & & & \\
\hline & 4.2 & 3.9 & 5.3 & 4.5 \\
Food & 54.0 & 48.5 & 52.1 & \\
(weight) & 0.3 & 8.0 & 0.9 & 1.9 \\
Beverages & 4.7 & 7.6 & 8.2 & \\
$\quad$ (weight) & 4.9 & -3.9 & -0.1 & 0.6 \\
Tobacco & 0.5 & 0.6 & 1.6 & \\
(weight) & 4.6 & -3.2 & 8.8 & 5.5 \\
Clothing & 8.9 & 7.4 & 11.6 & \\
$\quad$ (weight) & 3.4 & 2.3 & 1.5 & 2.1 \\
Accommodation & 19.7 & 19.4 & 10.7 & \\
$\quad$ (weight) & 2.4 & 3.8 & 1.5 & 2.0 \\
Health and hygiene & 4.6 & 4.3 & 5.3 & \\
$\quad$ (weight) & 0.0 & 2.4 & 0.5 & 0.6 \\
Transport and communication & 6.4 & 8.4 & 9.3 & \\
$\quad$ (weight) & & & & \\
& 3.8 & 3.3 & 4.8 & 4.3 \\
Total & & & & \\
& & & & \\
\hline
\end{tabular}

Sources: National Institute of Statistics; and staff estimates. 
Praia and Mindelo became relatively cheaper and the countryside more expensive. ${ }^{11}$ These divergent developments indicate distribution bottlenecks and problems in transporting goods from São Vicente's harbor facilities to the rest of the country.

19. These regional differences are especially pronounced when analysing the consumer price basket's primary item-food. As summarized in the accompanying Figure 3, food prices-particularly in the capital Praia and the rural areas-have increased at a faster rate than the prices for other goods and services. ${ }^{12}$ This phenomenon implies that throughout the country, the inflation tax is being disproportionately paid by the poorest segments of society. The bottom panel of Figure 3 shows the particular volatility of food prices, as well as the asymmetric nature of the fluctuations in food prices across these three regions. Between January 1996 and December 1998, food prices in the rural areas-where most of Cape Verde's poor live-increased faster, by 7.1 percent, than both the country's representative consumer price basket, which increased by an average 6.3 percent, and the region's aggregate price level (6.9 percent) ${ }^{13}$ It also highlights the particular significance that rural food price changes have on the overall inflation rate and, more importantly, hints at the possibility that the CPI basket of 1989-which, following the considerable increase in average income, likely over-represents the relative weight of food-has resulted in inflation figures consistently higher than the "actual" ones.

\section{Fiscal DeVEL OPMENTS}

20. The government's fiscal position improved markedly in 1998. Revenue increased considerably, while central government expenditure was essentially frozen. For the first time since 1994, the government was able to report a current balance surplus, which was largely due to its abstinence from pre-financing donor-supported investment projects with high

${ }^{11}$ While the consumer price index in the rural areas in 1996 was 1.5 percent lower than the national average, the cost-of-living advantage eroded to 0.3 percent in 1997 and tipped to a price premium over the national average of 0.2 percent in 1998. São Vicente, meanwhile, strengthened its price level advantage over the three-year period. While, in 1996, goods and services were about 1.4 percent cheaper than in the rest of the country, the gap increased to 5.1 percent in 1997 and 6.1 percent in 1998. A similar development-while on a much higher plateau - could be observed in Praia; its price level premium, which stood at 5.6 percent in 1996, fell to 4.6 percent in 1997 and 4 percent in 1998; see figure on the previous page.

${ }^{12}$ In all three regions, food items constitute approximately one-half of the representative basket of goods and services. The base year, on which the consumer price index is based, is 1980, the representative CPI basket dates back to 1989.

${ }^{13}$ Over the same period of time, food prices increased by an average of 5.8 percent (6.1 percent for all goods) in Praia and by 4.9 percent ( 4.2 percent for all goods) in São Vicente. 
interest domestic debt. In 1997, the government began to confront the increasingly serious problem by seeking external assistance for a large domestic debt-reduction operation.

\section{A. Overall Fiscal Developments}

21. During much of Cape Verde's period of transition, insufficient fiscal discipline has been the Achilles' heel of its economic policies. The difficulties were largely the result of the government's customary practice of financing large budget deficits with high-interest domestic debt to a degree that its ultimately unsustainable accumulation began to generate serious macroeconomic imbalances, which, in turn, threatened to hamper Cape Verde's entire structural adjustment program. ${ }^{14}$ In 1998, the government, however, managed to make considerable progress in consolidating its fiscal position (Table 15; see also Figure 4). Over the 12 months to end-1998, the government completely abstained from domestic bank financing, bridging its budgetary gap solely through concessional assistance from foreign creditors. Consequently, the deficit of the overall budget (on a commitment basis) could be brought down by about 6 percentage points, to 4.3 percent of GDP. The current balance, which stood at a deficit equivalent to 3.9 percent of GDP in 1997, tipped into a surplus of about 1.9 percent during the succeeding fiscal year.

22. Various factors contributed to this encouraging result: (1) the government improved its tax-collection efforts (as reflected in the 12 percent increase in tax revenue); (2) in order to offset higher interest expenditure, current primary expenditure was curtailed (in nominal terms, this item increased by only 1.5 percent) ${ }^{15}$ and (3) the government abstained from prefinancing donor-supported investment projects, implying that any shortfall in the externally financed component over initial budget projections led to a protraction in the execution rate of capital expenditures rather than an increase in domestic debt. ${ }^{16}$

\footnotetext{
${ }^{14}$ See para. 18 of EBS/98/18 (2/4/98), describing the urgency of fiscal reform at the time: "The more important concern was whether fiscal policy would finally be tightened sufficiently to begin to reduce inflation, to stop the rundown in reserves, and to ensure that there would be no further buildup of domestic debt." In this context, domestic debt has proven particularly burdensome, because of their high nominal interest rates. With an end1997 stock of domestic debt equivalent to 40 percent of GDP, the resultant domestic interest payments represented more than 13 percent of recurrent expenditure in 1998. External debt, by contrast, has been mostly concessional.

${ }^{15}$ The higher-than-projected interest payments had resulted from the delay in the domestic debt-reduction operation.

16 The foreign component of public-investment expenditures in 1998 increased by 11.5 percent over 1997. However, given that the fiscal problems of 1997 were reflected in an exceptionally low degree of foreign assistance, last year's increase simply restored external contributions to its 1996 level. Overall capital expenditure in 1998 was 2.2 percent lower than in 1997.
} 


\section{B. Government Revenue}

23. The government's commitment to strengthen its tax administration led to a considerable reinforcement in its collection capacity and an increased recovery of debt obligations from public enterprises. As a consequence, total revenues increased significantly, rising from CVEsc 8.8 billion (or 20 percent of GDP) in 1997 to CVEsc 11.7 billion (24 percent of GDP) in $1998 .{ }^{17}$ Of this increase, about CVEsc 1.3 billion came from the reimbursements of debt principals by public enterprises vis-à-vis the state; see Table 16. Tax revenues, as percentage of GDP, therefore continued on their moderately increasing trend (with the notable exception of 1997), mainly as a result of rising proceeds from taxes on international trade (Table 17). ${ }^{18}$

24. But even when the one-off revenues from public enterprise reimbursements are excluded (there were none in 1996 or 1997), the central government's tax and nontax revenue still increased by a nominal 18 percent between 1997 and 1998, thus increasing the revenue-to-GDP ratio from 19.5 to 21.3 percent. While this figure is broadly in line with the results of 1994-96, ${ }^{19}$ tax revenue, expressed in terms of GDP, increased in 1998 by half a percentage point from the 1994-97 annual average of 16.8 percent, thereby signifying the degree to which it was possible to strengthen the country's tax administration throughout the fiscal year 1998 .

\section{Expenditure Developments}

25. Total expenditure (Tables 18 ) has remained approximately constant, at about CVEsc 19 billion during the four-year period between 1995 and 1998. In fact, the overall structure of expenditures in 1998 did only incrementally change from the year before; with no significant adjustments to almost any of the main items in either recurrent and capital expenditures. This outcome is consistent with the government's objective to gradually diminish the state's importance within the Cape Verdean economy. By 1998, central government spending, in percent of GDP, declined from its 1995 level of almost one quarter by almost three percentage points.

26. The only fiscal priority, which was set by the government in 1998, has been the increase in public spending for wages and salaries. The 1997-98 increase of about 8 percent-well above the nominal wage increase for public sector employees-included additional recruitment for Cape Verde's ongoing program of strengthening its educational system (Table 20). These extra expenditures were partly offset by reduced subsidies and

\footnotetext{
${ }^{17}$ CVEsc 100 are approximately equal to US\$1.

${ }^{18}$ Effective January 1, 1999, the government eliminated all remaining quantitative import quotas, while adopting a simplified - but somewhat elevated - tariff structure, thus reinforcing the importance of taxes on international trade.
}

${ }^{19}$ The total revenue-to-GDP ratio was 21.1 percent in 1994, 21.9 percent in 1995 (excluding public enterprise reimbursements), and 21.1 percent in 1996. 
transfers to the public sector. Consequently, recurrent expenditures, in nominal terms, rose by only about 1.8 percent-substantially less than the average inflation rate.

27. The foreign-financed element of capital expenditures rose by 11.5 percent in 1998 , despite significant delays by donors to disburse loans and grants earmarked for public investment projects. However, following the government's decision to abstain from its previous habit of simply pre-financing these items, the domestically financed portion declined (by 50 percent), resulting in a further decline of public investments relative to output to 17 percent of GDP. This trend began in 1994, when the ratio stood at about 32 percent of GDP.

\section{Domestic Debt}

28. As a result of continued recourse to domestic bank financing throughout the early transition period 1992-96, the stock of domestic debt grew to unsustainable levels (Tables 19 and 28). At end-1997, it stood at CVEsc 18 billion, or 40 percent of GDP. This meant that domestic debt-service payments - about 13 percent of recurrent expenditure-consumed more than 3 percent of GDP in 1997. In 1998, the government abstained from any further increase of domestic debt financing (Figure 4), while restructuring its existing stock of domestic debt in 1998 (Figure 5), converting CVEsc 1.4 billion of short-term and CVEsc 0.1 billion of medium-term debt into long-term debt.

29. To remedy this situation, the government began to seek external financial assistance in early 1997 to support a large domestic debt-reduction operation. It sought donor contributions in the amount of US\$100 million (about CVEsc 10 billion) and pledged to contribute US $\$ 80$ million (CVEsc 8 billion) from privatization revenues to be invested in an offshore trust fund. Since the repayment of all the domestic debt would have resulted in a very large liquidity injection into the economy, it was decided to place the mobilized resources in a trust fund and to swap the existing (high-interest) government debt against (lower-interest) claims on the trust fund's revenue, referred to as titulos consolidados de mobilização financeira (TCMFs). These are to be bought back by the government as fiscal and monetary conditions permit. Of the US\$80 million that international donors had already pledged in the form of grants and loans, US $\$ 29$ million had been deposited into the trust fund by end-1998; the majority of privatization revenues and external contributions are expected for 1999. The government sought-and, in June 1998, was given - parliamentary approval for the regulations governing the trust fund. Since no conversion took place in 1998, the interest payments on domestic debt remained at the high level of 3.9 percent of GDP. 
Figure 4. Cape Verde: Central Government Budget, 1991-98

(In percent of GDP)

Central Government Revenue
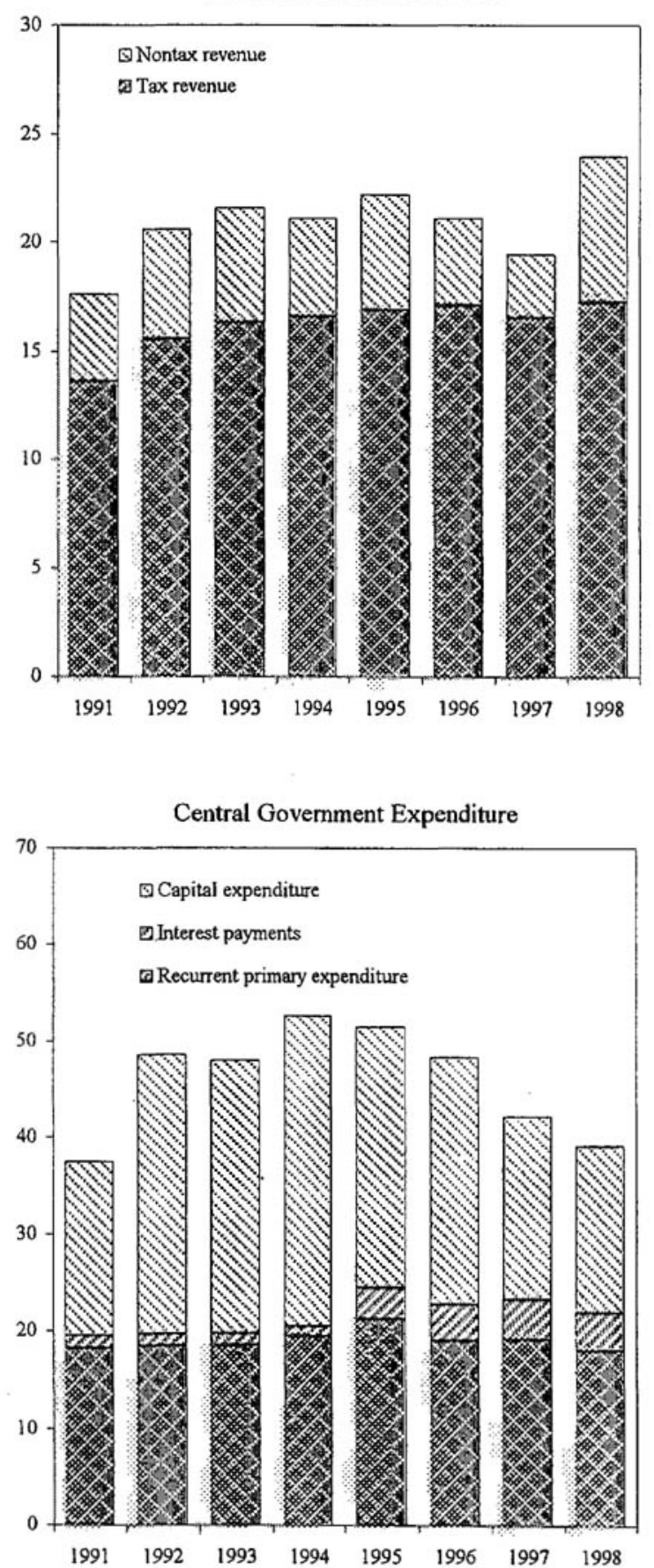

Budget Deficits (Including Grants)

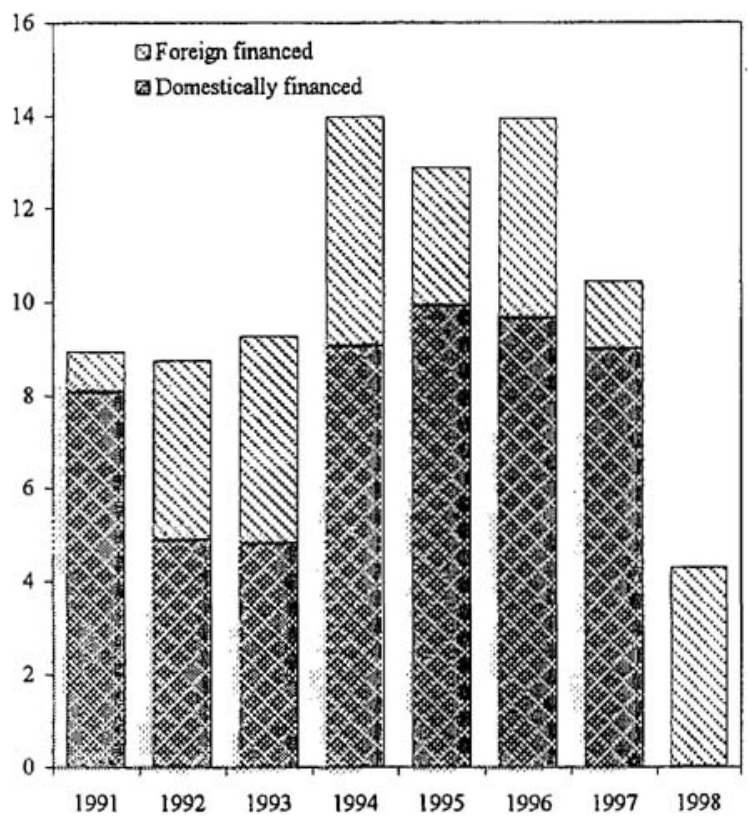

External Budgetary Support

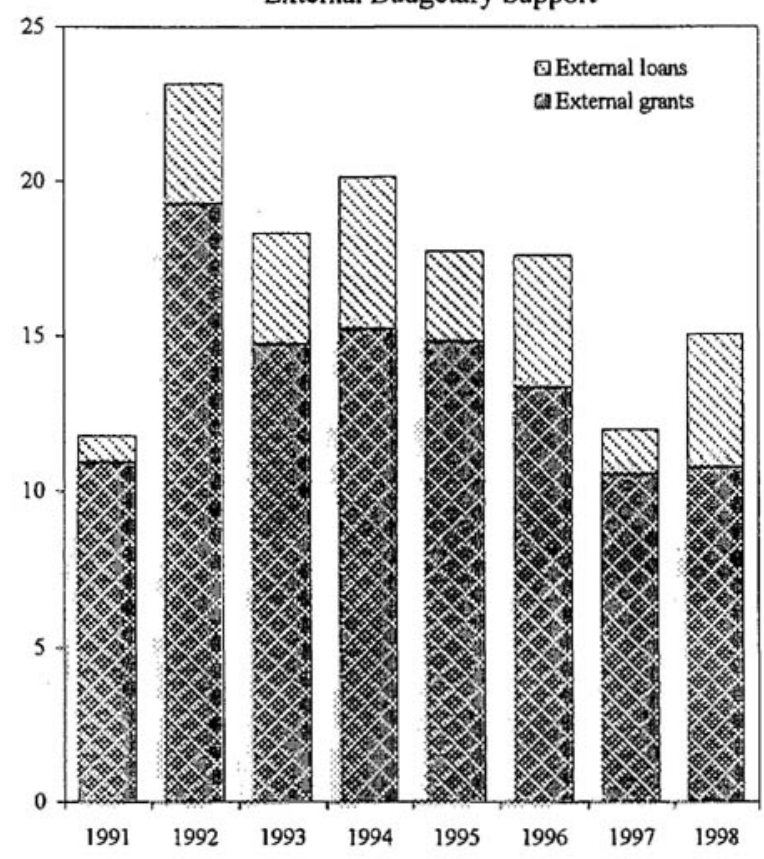

Sources: Ministry of Finance; and staff estimates. 
Figure 5. Cape Verde: Public Debt, 1991-98
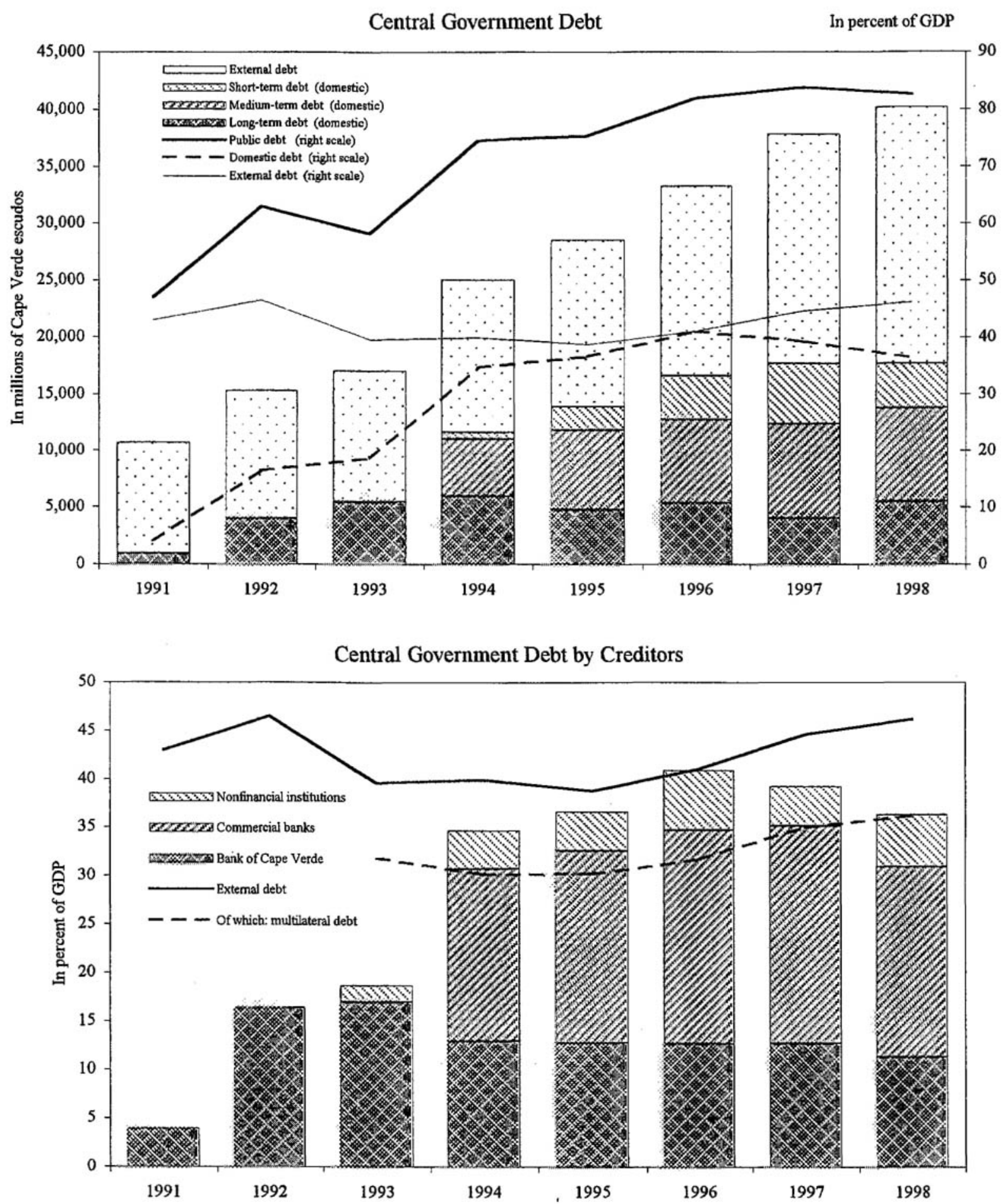

Sources: Ministry of Finance; Bank of Cape Verde; and staff estimates. 


\section{MONeTARY POLICIES}

30. Given Cape Verde's fixed exchange rate regime, monetary policy is oriented towards the goal supporting the escudo. After mixed results in 1997, leading to a rise in inflation, declining net foreign assets, and a considerable appreciation in the real effective exchange rate, monetary control was noticeably tightened in 1998. Broad money grew by less than two percent, allowing inflationary pressures to recede and the banking system 's foreign reserves to increase (albeit moderately).

\section{A. Monetary Policy Objectives}

31. Cape Verde's monetary environment is shaped by its fixed exchange rate regime, which commits the Bank of Cape Verde (BCV) to use monetary policy goals to maintain the escudo's peg. Following an overly loose policies in 1997-as, for instance, signified by the 26 percent expansion in credit to the economy, the 20 percent increase in domestic credit, the12 percent growth in broad money, the 8.6 percent in average annual inflation, and, lastly, the 5.5 percent appreciation in its real effective exchange rate (see also figure below)-the BCV clearly needed to steer against the trend of further expansion. In fact, the monetary environment had turned decidedly unfavorable by end-1997: the central bank's net reserves (and with it, the confidence into the nominal exchange-rate peg) had declined to two months of imports of goods and nonfactor services. Worse still, the monetary uncertainty lasted well into mid-1998, when it became clear that neither the rapid expansion of credit to the economy had not been contained $^{20}$ nor the fears of further realignments (beyond the one at end-March 1998) been relieved. Both developments detrimentally affected the influx of workers' remittances, while coinciding with the government's adoption of a new foreign exchange law (which liberalized currentaccount transactions) and the switch from the previous Real Effective Exchange and Average Annual Inflation Rates

basket to a single-currency peg (see below). Without the possibility of adjusting the weights

${ }^{20}$ In mid-1998, the annual growth rate of "credit to the economy"-based on end-December 1997 to end-June 1998 figures-was estimated to equal 15 percent; the revised figures show an annualized expansion of "only" 13 percent during this period. 
of the partner countries' weights within the basket, particular importance had thus implicitly been placed on the improvement of the banking system's "net foreign asset" position.

\section{B. Recent Monetary Developments}

32. Following the tightening of monetary policies in (the latter half of) 1998, net foreign assets of the banking system did indeed increase (albeit slightly), from US\$58.3 million (CVEsc 5,613 million) in end-1997 to US\$59.9 million (CVEsc 5,646 million). This result is, however, more positive than the numbers would indicate, since it has to be viewed within the context of the authorities' third and fourth quarter efforts aimed at reducing the foreign exchange queue, which had been accumulating since end-1995. ${ }^{21}$ The backlog of applications declined from its June 1998 level of CVEsc 3.8 billion (US\$38 million) to CVEsc 0.8 million (US\$9 million) by year's end. The banking system as a whole spent-net of cancellations ${ }^{22}$ - an equivalent of CVEsc 1.8 billion on this operation, mainly as a result of the central bank's transfers of foreign reserves to the country's financial institutions. Over the same end-June to end-December period (no data for the size of the queue are available for December 1997), the central bank lost close to CVEsc 1 billion in reserves, while the commercial banks-which were successful in attracting expatriate savings with special, highyielding "emigrant accounts"-increased their stock of net foreign assets by almost CVEsc 0.7 billion. Thus, the amount of reserves lost by the banking system as a whole-CVEsc 0.3 billion-was significantly less than the amount used to reduce the queue. Central bank reserves (net of the backlog) consequently increased, as shown in Figure 6, at a considerable rate.

33. The real sector's dynamism during 1998 was reflected in the considerable 12 percent increase of the "credit to the economy" item; see Table 22. This rise was, however, offset by reduced net claims to both the central and local governments and a lower "other items (net)" figure, which reflects the increased profitability of the commercial banks; see Table 21 . As a result, net domestic assets rose by the modest amount of 2.1 percent (or 1.7 percent in terms of beginning-of-period money stock). The resultant slowdown in broad money growth-from 12.1 percent in 1997 to 1.8 percent in 1998 -led to a situation, in which inflation could decline and the real effective exchange rate depreciate.

${ }^{21}$ The queue consists of approved, but unmet applications of foreign exchange for current transactions at the commercial banks. The government eliminated it in April 1999, later than as originally envisaged. The delay is partly due to the postponement of a US\$5 million tranche in balance-of-payments aid, initially promised for July 1998.

${ }^{22}$ In order to separate real from fictitious demand, the authorities required importers to leave a sizeable deposit, remunerated at market rates, with the banks during the SeptemberDecember period. They also made importers supply the remaining domestic-currency equivalent within five working days, once the foreign currencies had been made available. 
Figure 6. Cape Verde: Selected Monetary Indicators, 1995:Q1 - 1998:Q4
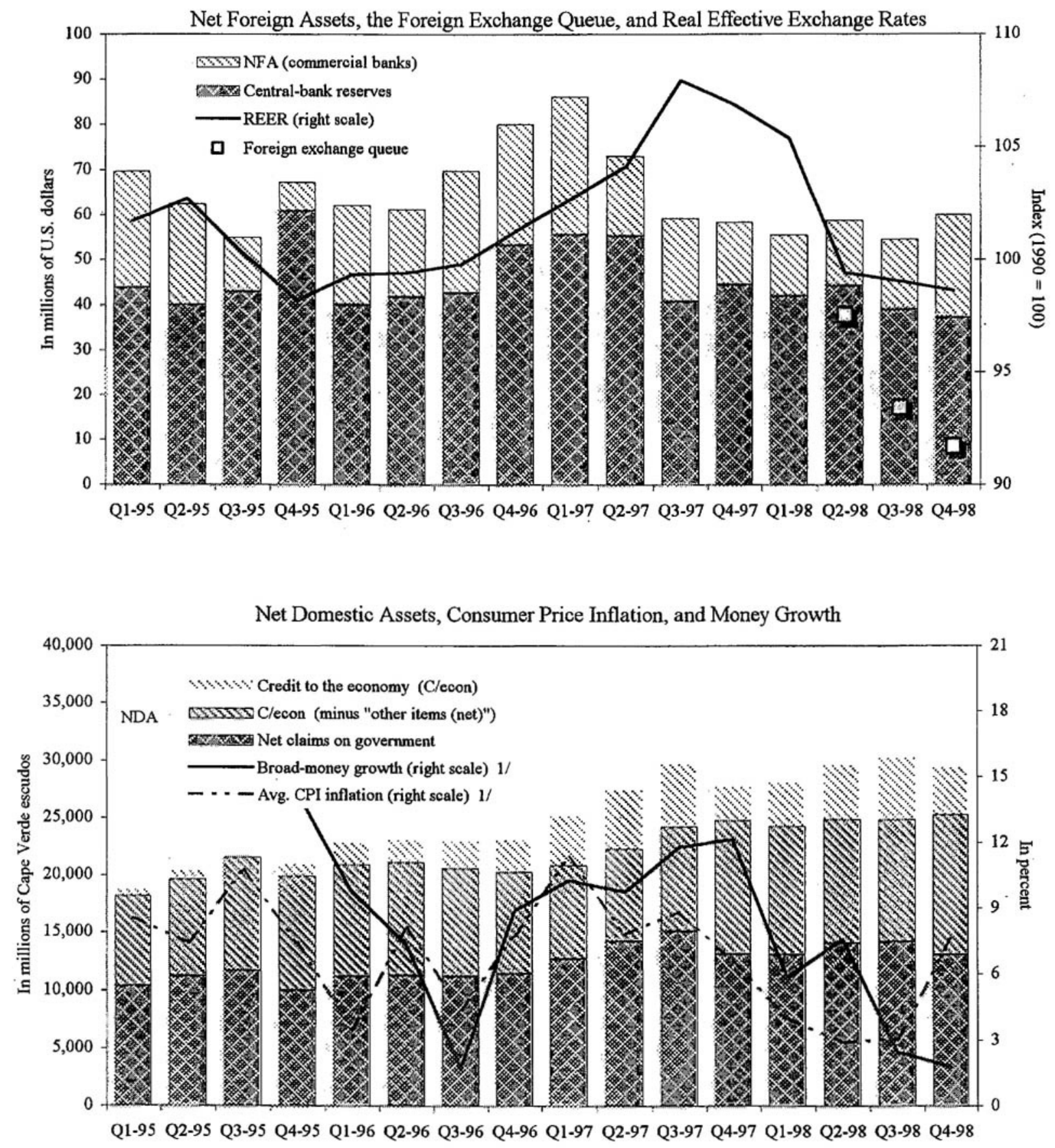

Sources: Bank of Cape Verde, Ministry of Finance; National Institute of Statistics; IMF's Information Notice Service; and staff estimates. 


\section{Box 4. Recent Developments in Cape Verde's Banking Sector}

The establishment of independent commercial banks. The development of a modern banking system in Cape Verde took place in two phases. First, in 1993, Cape Verde's monobank - the Banco de Cabo Verde (BCV)-and the national post office transferred their respective commercial-banking activities to new, publicly-owned universal banks-the Banco Comercial do Atlântico (BCA) and the Caixa Económica de Cabo Verde (CECV), respectively. The main constraints at the time were the lack of standardized accounting practices, the absence of an effective supervisory framework, and a heavy dependence on financing from the treasury.

Competition and privatization. Second, building on the progress made in solving the aforementioned problems, Cape Verde's banking system has been set on the path towards domestic competition and the privatization of all of its commercial banks. Two foreign banks - the Banco Totta e Açores in 1996 and the Caixa Geral de Depósitos in 1998opened branches on São Tiago and São Vicente (with plans to expand their activities to Sal and, ultimately, to all the islands). With an already established network of branches abroad, these two banks are in a particularly favorable position to further strengthen the relationship with Cape Verde's extensive émigré community. At the same time, the government passed legislation that has prepared the way for the privatization, supported by the World Bank, of both the BCA and CECV. The transfer of ownership will be concluded by end-1999.

Reinforcing the regulatory system. Concomitantly, the authorities stepped up their efforts in reinforcing the regulatory system in order to ensure the adequate supervision of banking activities in the new era of competition and private ownership. In particular, the central bank redefined the risk categories of, and tightened the prudential reserve requirements for, credits provided to households and private enterprises in 1998 (see BCV Regulation 09/98 of 12/28/98). The BCV furthermore demanded that banks clean up their portfolios-e.g., by entering into rescheduling agreements with debtors in default-, leading to a sharp decline in the domestic banks' nonperforming loans, while increasing the resources for on-site bank supervision.

Electronic network-and-payment systems. The commercial banks, meanwhile, upgraded their communication networks, permitting transfers between branches and headquarters in real time and providing for the development of reliable, centralized accounting systems. In 1999 , a further computerization will allow for the development of real-time interbank transactions and the establishment of an electronic clearing system between the commercial banks and the BCV. Thus, both debit and credit cards will be introduced in Cape Verde throughout the second half of 1999. Already, the banking system has been integrated-as of January 1999 - into the Society for Worldwide Interbank Financial Telecommunication (SWIFT). 
34. Despite the falling inflation rates, basic lending rates in 1998 remained at their high plateau of between 12 and 14 percent, depending on the credit's maturity (Table 29). At the same time, deposit rates tended to remain constant. The continuously large discrepancy between the lending and deposit rates reflects the banks' unabated risks in recovering loans as well as the inadequate degree of competition among the commercial banks and the limited development of money and financial markets. To correct for these weaknesses, the authorities are strengthening the BCV's supervisory role and are in the process of promoting the formation of an interbank deposit market, with further plans to develop one for short-term central bank deposits.

35. In the wake of Cape Verde's monetary modernization program, two foreign banks have opened branches in recent years, stimulating the competition among the country's commercial banks, notably over emigrant resources (Box 4 and Tables 22-27). The émigré deposits-which are key to reducing the banks' dependence on central bank transfers of foreign exchange-rose by 9.3 percent to CVEsc 8 billion at end-December 1998, thus increasing their shares in relation to the commercial banks' overall domestic liabilities from 24.7 percent in 1996 to 25.5 percent in 1997, and to 27.2 percent in 1998.

\section{EXChange Rate Policies and EXTERnal SECTOR DEVelopMents}

36. The external sector, while being supported by the liberalization of current account transactions, was being hit by several exogenous shocks affecting trade, leading to considerably lower exports of goods and nonfactor services. The significant increase in private transfers and travel-related service receipts, however, helped to keep the current account (excluding official current transfers) broadly stable at a deficit of about 17 percent of GDP.

\section{A. Exchange Rate Policies}

37. In regards to exchange rate policies, major reforms were approved and adopted in mid-1998. To facilitate commerce, travel, and the international transfer of funds, the government passed a new foreign exchange law that liberalized current account and capital transactions; this policy was aimed at ensuring the escudo's convertibility. ${ }^{23}$ It replaced the basket peg of the Cape Verde escudo with a fixed Esc/CVEsc link ${ }^{24}$ in order to signal the

${ }^{23}$ Decree-Laws 25/98 and 26/98 of June 29, 1998, in conjunction with the central bank's adoption of the regulations $2 / 1998$ and $4 / 1998$. The latter increased individual travel allowances and defined a revised list of capital transactions that continue to require prior authorization and/or verification by the central bank.

${ }^{24}$ Portugal supports Cape Verde's exchange rate regime with a precautionary US\$50 million credit facility, jointly managed by both governments through the Commissão do Accordo de Cooperação Cambial (COMACC). As of January 1, 1999, the Cape Verde escudo has been pegged to the Portuguese escudo's successor currency, the euro. In late 1998, the European continued 
Cape Verdean authorities' determination to bring inflation under control. And finally, the $\mathrm{BCV}$ completed this process of structural trade regularization through its increased willingness to transfer exchange reserves to the commercial banks in order to allow them-as discussed above- to pay off the queue of approved (but unmet) applications for foreign currencies.

38. The foreign exchange law of June 29, 1998 removed all restrictions to both capital and current account transactions $\mathrm{s}^{25}$ and permitted residents to open accounts in foreign currency. These new guidelines require that international transfer of funds actions be channelled through financial institutions explicitely authorized to trade in titles denominated in foreign currencies. They also reclassified violations as "infractions" and thus effectively decriminalized the infringement of the exchange law's legal requirements.

39. The shift in the foreign exchange regime removed an instrument periodically applied by the $\mathrm{BCV}$ - the changing of currency weights within the basket, against which the escudo was pegged. The analysis of the appropriateness of the peg at any point in time has thus been facilitated, with net foreign assets being the crucial variable. By increasing the transparency of Cape Verde's exchange rate regime, this switch-while reflecting the increasing importance of Western Europe as trading partner-was designed to bolster confidence.

\section{B. External Sector Developments}

40. One crucially important confidence indicator in Cape Verde-next to the country's reserve position, which slightly improved-is the amount of remittances sent by the country's extensive emigrant community. After they had considerably dropped in 1996, 1997 , and early $1998,{ }^{26}$ they recuperated significantly during the final months of the year. The end-of-year figure for 1998 actually showed a 17 percent increase over 1997. At the same time, however, Cape Verde received fewer export and service receipts (mainly for exogenous reasons), which-overall-resulted in a modest deterioration in the current account. The capital and financial account remained in a surplus position. External debt increased, both in absolute terms and relative to GDP; this trend stemmed, in part, from the rescheduling arrangements of a large part of Cape Verde's external arrears (Tables 30-31).

Commission had accepted the supporting Portuguese-Cape Verdean exchange rate arrangement. Thus, after the euro was launched, the Esc $1=$ CVEsc 0.55 peg was replaced by the corresponding $€ 1=$ CVEsc 110.27 rate.

${ }^{25}$ With the notable exception of travel-related transactions: upon presentation of the required travel documents, Cape Verdeans may now exchange CVEsc 1,000,000 per person per tripirrespective of the number of trips made (until then, the ceiling had been fixed at CVEsc 100,000). Only a very small number of travellers has requested an amount in the vicinity of this limit, with the average application being about one-fifth of it.

${ }^{26}$ Data compiled by the Bank of Cape Verde for the first and second quarters of 1998 seemed to indicate in mid-1998 that workers' remittances would decrease by as much as 18 percent. 


\section{Merchandise Trade}

41. After several years of steady export growth, sales of goods and nonfactor services decreased moderately, by about 1 percent, mainly as a result of significantly declining sales of fish, crustaceans, shoes, and fuel. The 28 percent decline in the export of goods, however, was significant and caused, for the most part, by exogenous shocks, all of which are likely to be temporary. In particular, sales were hampered by (1) the absence of valuable fish stocks in Cape Verdean waters, (2) the expansion of productive capacities by several major exportoriented enterprises (which required the interruption of production), and (3) the cancellation of flights to and from Sal by one important airline, and (4) the truncation of shipping routes from Europe via Cape Verde to war-torn Guinea-Bissau. The latter two events adversely affected fuel reexports, which represent approximately two-thirds of overall exports (Table 32).

42. Despite rapid growth rates in the import-intensive sectors tourism and construction, these remained broadly stable in 1998; see Table 33 . This follows not only the decline in prices of several important products but also the decrease in the volume of petroleum product imports (for the reasons given in the preceding paragraph). Imports of consumption and equipment goods, on the other hand, increased in line with the economic growth, while foodstuff imports-following the severe autumn drought-rose faster than economic output.

43. While Cape Verde's overall trade deficit increased by almost a nominal 9 percent in 1998, its importance relative to GDP-which had declined from 42 percent in 1994-95 to about 351/2 percent in 1996-97-remained on the level that had been established during the two preceding years. Adjusting for the adverse shocks to Cape Verde's, this result represents a considerable structural improvement in its-still delicate-external trade position.

\section{Services and Transfers}

44. The adverse developments in the aerial and maritime transport sectors discussed above are clearly mirrored in the service account (Table 34), with declining receipts for passenger, port, and airport services. This deterioration on the credit side, however, is more than offset by the 55 percent increase in travel-related receipts (see figure to the right), reflecting the ongoing investment in -and the resultant expansion of - this sector, which has been observed since 1996. At the same time, Cape Verdeans took advantage of the liberalized travel allowances, and the changes in exchange rate policies have instigated a noticeable rise in domestic travel expenditures. Moreover, the temporary truncation of the maritime Europe-Cape Verde-Guinea-Bissau route

Tourism Demand in Cape Verde

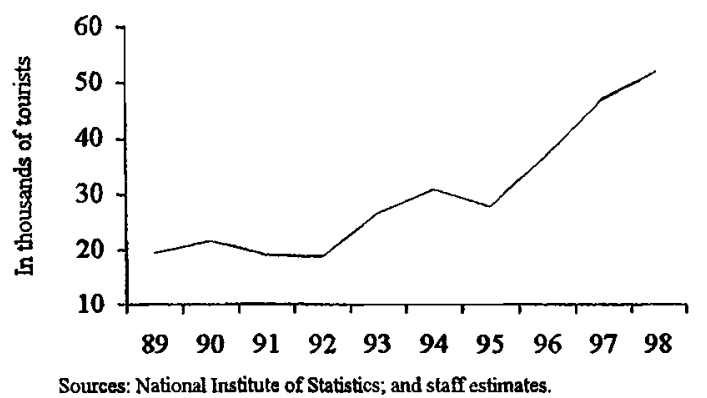

Sources: National Institute of Statistics; and staff estimates. 
required Cape Verdean importers to pay higher ship-chartering and freight fees. Both events led to a 17 percent deterioration of net services, equivalent to approximately one percent of GDP.

45. The year 1998 did not see any significant to the overall factor income balance (Table 36), which remained at its relatively constant deficit of around one percent of GDP. The income streams on both on the credit and debit sides declined moderately. The main receipt items continued to be the interest earned on time deposits at foreign banks and the compensation of employees by foreign firms. On the debit side, there has been a strong growth of dividend payments-reflecting increased foreign investments-and of interests on the external debt.

46. With the exception of the economically difficult year 1997 , net transfers remained at a broadly constant level of CVEsc 13-14 billion. If expressed in terms of GDP, this represents a gradual decline in their importance. Private transfers, which are more closely correlated with the country's monetary soundness, responded in a particularly elastic manner to the economic uncertainty (in the government's exchangerate policy) in 1997 and early 1998

Workers' Remittances (Net)

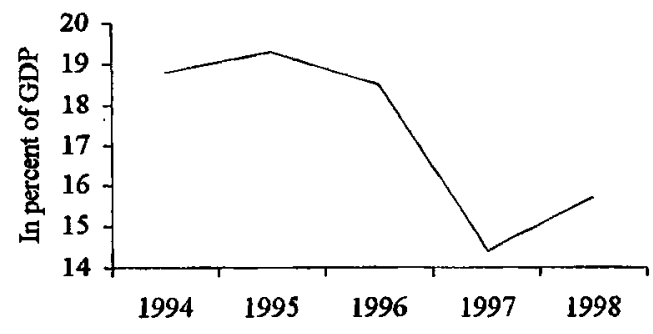

Sources: Bank of Cape Verde; and staff estumates.

(Table 37). Once the official rate of the Portuguese escudo was finally confirmed in early July 1998, workers' remittances-which had been less than CVEsc 2.7 billion in end-June 1998 - recovered to CVEsc 7.6 billion by year's end; see also figure to the right. Food aidworth slightly more than 2 percent of GDP in 1996-98-remained an important source of income in Cape Verde (Table 38).

\section{E. Capital and Financial Account}

47. Throughout the period 1994-98, the capital and financial account balance displayed large surpluses of - on average, and with a considerable degree of variability-CVEsc 6.8 billion (or 16.4 percent of GDP). Direct and portfolio investment flows rose sharply during the period 1994-96, favorably responding to the enactment of a new legislation aimed at attracting foreign capital and promoting export diversification. ${ }^{27}$ Those flows amounted to CVEsc 2.3 billion (US\$28 million or close to 6 percent of GDP) in 1996. The subsequent decline in 1997-98 reflects, to a significant degree, the initial delays of the implementation of the country's comprehensive privatization program (see below).

48. Central government and public enterprise borrowing (Table 40) showed a rising trend during the 1994-98, peaking at CVEsc 2.3 billion (US\$23.5 million or 4.8 percent of GDP)

27 The high direct investment and portfolio flows in 1996 partly reflect foreign investors purchase of shares (US\$6 million) in the privatized national telecommunication company. 
in 1998, owing, in part, to Cape Verde's drawing on a new World Bank credit facility (Economic Reforms Support Operation, ERSO). Amortization has risen correspondingly, as the stock of debt has increased. Also, several important loans' grace periods expired.

\section{F. External Debt}

49. Cape Verde's increasing reliance on externally financed deficits stems from the trend increase of total outstanding external debt (Tables 39, 42, and Figure 5), from CVEsc 11.5 billion (US\$143.5 million or 39.5 percent of GDP) in 1993 to CVEsc 22.5 billion (US\$23 million or 46.2 percent) in 1998 - with the relatively lowest amount of outstanding debt being recorded in 1995. The increase is, in part, the consequence of the government's efforts made to reschedule external arrears. Last year's figure is roughly in line with the one recorded in 1992 (46.5 percent of GDP). Most of the external debt was contracted on concessional terms - all of the new loans in 1998 were - and incurred primarily with multilateral institutions, the debt to whom accounts for more than three-fourths of the total.

50 Of the 1998 amount of

external debt, CVEsc 855 million (US\$9 million or 1.8 percent of GDP) represented arrears on principal and interests (Table 41)-compared to CVEsc 955 million (US\$ 10 million or 2.1 percent of GDP) at end-1997 and CVEsc 2.1 billion (US\$ 25 million or 5.2 percent of GDP) at end-1996. By 1996 , the arrears situation-as depicted in the figure to the right-had

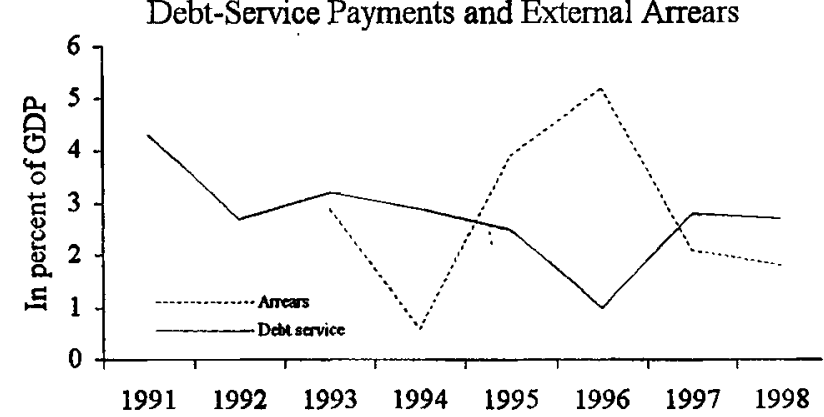

Sources: Cape Verdean authorities; and staff estimates. deteriorated to a point that made the major debt-rescheduling operation 1997-99 a policy of paramount importance. With an increasing stock of debt after 1995, debt-service payments increased accordingly, with a one year delay. The concessional nature of the new external debt, which was incurred in 1997 and 1998 , is reflected in the declining ratio of debt-service payments to GDP: it fell from 2.8 percent of GDP in 1997 to 2.7 percent in 1998, despite the increase the external debt-toGDP ratio.

\section{STRUCTURAL REFORMS}

51. The government continued its comprehensive program of structural adjustments. In 1998, it launched its World Bank-supported privatization program that aims at transferring the ownership of 27 state-owned enterprises. Concomitantly, all remaining quantitative import restrictions were removed and a social emergency fund created.

\section{A. The National Development Plan 1997-2000}

52. With the conclusion of the initial transition phase during the mid-1990s, the government outlined its fundamental medium-term goals in an ambitious national 
development plan for the 1997-2000 period. The policies outlined in this plan are designed to achieve and maintain internal and external equilibria in the economy and to support and strengthen the private sector-in both a socially and environmentally sustainable manner. To that end, the government endeavored to pursue comprehensive reform programs to (1) modernize public administration, (2) develop land and natural resources, (3) improve economic and transportation infrastructure, (4) promote human and social development, and (5) strengthen and consolidate democracy in Cape Verde. ${ }^{28}$

\section{B. The Privatization Program}

53. Within this broader framework, Cape Verde's economy currently finds itself in the midst of a comprehensive privatization program. The transfer of ownership of its publiclyheld enterprises (see Box 5) -implemented in close coordination with the World Bank-is to provide about 45 percent of the contributions to the trust fund.$^{29}$ But this program is also a vehicle for the government to demonstrate, both to Cape Verdeans and the international donor community, its commitment to give up the direct control over most economic activities. Following the completion of the privatization process, which is expected to raise annual revenues averaging approximately $3 \frac{1}{2}$ percent of GDP during the 1998-2002 period; the government will control only the post office and the social security agency. It will, however, retain a minority shares in the public utilities and the banks.

\section{Trade Liberalization}

54. The government continues to open the domestic market, exposing it to both internal and external competition. The encouragement of internal competition is, for instance, symbolized by the reforms to the procurement company EMPA, ${ }^{30}$ which is not only being privatized but also-effective January 1,1999-disposed of its remaining import monopolies of sugar, oils, corn, and rice. These changes were introduced in the context of a broader trade liberalization program, centered around a new trade law that replaced all remaining

${ }^{28}$ See Ministry of Economic Coordination, The National Development Plan 1997-2000: Dynamic Integration of Cape Verde into the World Economy (Praia: Republic of Cape Verde), 1997.

${ }^{29}$ Both domestic and external disbursements to the trust fund were delayed for mainly administrative reasons, both largely beyond the control of the government. The US $\$ 29$ million contributions in 1998 were thus below the initial expectations of US $\$ 95$ million. This obliged the authorities to postpone the debt-conversion operation until 1999.

${ }^{30}$ EMPA, which is being transformed into an-ultimately private-import-and-distribution company, enjoyed the monopoly over the import of a-gradually declining-number of key commodities, mainly food items. Moreover, EMPA had been selling the staple commodities obtained through food grants at international prices, the profits of which were transferred to the treasury for the purpose of financing the government's labor-intensive public works programs. 


\section{Box 5. Cape Verde's Accelerated Privatization Program 1998-2002}

With the timely implementation of its privatization program, the government is pursuing two overriding goals, viz., (1) to increase the role of the private sector in the Cape Verdean economy, and (2) to be able to provide the committed US $\$ 80$ million in domestic financial resources to the trust fund, which supports the country's large domestic debt-reduction operation. The offer for sale of all the enterprises listed below has either occurred or is scheduled to start during the course of 1999 and 2000. The full proceeds of these transactions, however, are expected to be received over the five-year period between 1998 and 2002 , averaging about $3 \frac{1}{2}$ percent of GDP per annum throughout this period--with the largest revenues projected for 1999 (about 7 percent of GDP) and 2000 (about 8 percent of GDP).

\begin{tabular}{|c|c|c|c|c|}
\hline $\begin{array}{l}\text { Cash Flow } \\
\text { (1998-2002) }\end{array}$ & Enterprise & Sector & $\begin{array}{c}\text { Sales }^{2} \\
(\ln 1997)\end{array}$ & $\begin{array}{l}\text { Wages }^{2} \\
\text { (In 1997) }\end{array}$ \\
\hline
\end{tabular}

I. Companies privatized in 1998

(In millions of Cape Verde escudos)

$\begin{array}{rllrl}\bullet 0000 & \text { FAMA } & \text { Pasta } & 97 & 13 \\ \bullet 0000 & \text { MOAVE } & \text { Flour } & 447 & 39 \\ \bullet 0000 & \text { SONACOR } & \text { Maintenance } & 31 & 38\end{array}$

II. Companies to be privatized in 1999-2000

$\begin{array}{cllcc}\bullet \bullet 000 & \text { ANV } & \text { Travel } & 33 & 32 \\ 0 \bullet \bullet 00 & \text { ARCA VERDE } & \text { Maritime } & 215 & \mathbf{9 4} \\ 0 \bullet \bullet \bullet & \text { BCA } & \text { Bank } & \ldots & \ldots \\ 00 \bullet \bullet & \text { CABNAVE/CABMAR } & \text { Shipyard } & 286 & \mathbf{1 5 8} \\ 0 \bullet \bullet 0 & \text { CECV } & \text { Bank } & \ldots & \ldots \\ 00 \bullet 00 & \text { CERIS } & \text { Beverage } & 933 & 125 \\ 00 \bullet 00 & \text { CORREIOS } & \text { Post } & 174 & 162 \\ 000 \bullet 0 & \text { CSLINE } & \text { Shipping } & \ldots & \ldots \\ 0 \bullet 000 & \text { CVC } & \text { Construction } & 298 & 76 \\ \bullet \bullet \bullet \bullet & \text { CVTELECOM } & \text { Telecom } & 2,456 & 421 \\ 0 \bullet \bullet \bullet & \text { ELECTRA } & \text { Electricity } & 1,187 & 290 \\ 0 \bullet \bullet 0 & \text { EMPA } & \text { Procurement } & 4,983 & 467 \\ 00 \bullet 00 & \text { EMPROFAC } & \text { Pharmaceutical } & 556 & 41 \\ 0 \bullet 000 & \text { ENACOL } & \text { Petroleum } & 1,236 & 152 \\ 00 \bullet 00 & \text { ENAPOR } & \text { Port administration } & 946 & 41 \\ 0 \bullet 000 & \text { GARANTIA } & \text { Insurance } & 352 & 58 \\ 0 \bullet 000 & \text { INERF } & \text { Rural works } & \ldots & \ldots \\ 00 \bullet 00 & \text { INTERBASE } & \text { Fish marketing } & 55 & 42 \\ \bullet 0 \bullet 00 & \text { INTERBETAO } & \text { Construction } & \ldots & \ldots \\ \bullet \bullet \bullet \bullet \bullet & \text { OFICINAS } & \text { Repair shop } & \ldots & \ldots \\ 0 \bullet \bullet 00 & \text { PROMOTORA } & \text { Venture capital } & \ldots & \ldots \\ 000 \bullet 0 & \text { SEA INVEST } & \text { Shipping } & \ldots & \ldots \\ 00 \bullet \bullet & \text { TACV } & \text { Airline } & 4,152 & 848 \\ 0 \bullet 000 & \text { TRANSCOR } & \text { Public transportation } & 300 & 150\end{array}$

1. Expected privatization revenues, net of retrenchment costs, for the entire 1998-2002 period. - refers to years with expected cash flows to the government, $O$ for years with none. Revenue estimates were made by the privatization agency, GARSEE (Gabinete de Apoio $a$ Reestruturação do Sector Empresarial do Estado).

2. For SONACOR, sales and wage figures are for 1996. 
quantitative export restrictions with revised customs duties. ${ }^{31}$ These changes became effective on January 1, 1999, including new duties that, temporarily, provide significant protection for certain domestically produced goods. The average (unweighted) tariff rate of the 5,701 products listed under the new customs regime-with now only a few different rates-is close to 20 percent. This represents an increase in tariff protection by an average of about 5 percentage points

\section{Social Policies}

55. Antipoverty policies and the building of social infrastructure occupy a central place within the government's overall program of economic liberalization. The national development plan includes as a pivotal component a Poverty Alleviation Program (PAP) primarily targeted towards (1) women heading households, (2) young unemployed, (3) "disadvantaged groups". as specified in the PAP and (4) workers that have become dependent on the government's food-for-work programs. Community-based and organizationally inclusive, the antipoverty policies, as documented in several World Bank documents, aim at fighting the causes (rather than the symptoms) of poverty, thereby attempting to show the participants and their children a possible way out of their destitute situations. Food-for-work programs continue to complement the PAP and represent an indispensable safety net of last resort for the poor.

56. As the country is particularly exposed to climatic vicissitudes and natural disastersthe latest example being the severe autumn drought of 1998, which has all but destroyed agricultural production on several islands-the government responded by establishing a special emergency fund, the Fundo Especial de Estabilização e Desenvolvimento (FEED), from which to draw on in cases of droughts, floods, volcanic eruptions, or epidemics. The FEED, legally established in August 1998, will be financed through privatization revenues and from a 5 percent share of trust fund earnings. Its initial operation will be an emergency public works program in 1999, targeted at alleviating the socioeconomic impact of the previous year's drought on some of the most disadvantaged members of Cape Verdean society.

\footnotetext{
${ }^{31}$ Products affected by this law include meat, yogurt, tomatoes, onions, bread, beer, paint, soap and detergents, and furniture.
} 


\section{HAS CAPE VERDE'S STRUCTURAL ADJUSTMENT PROGRAM LED TO AN INCREASE IN INTERNATIONAL COMPETITIVENESS?}

\section{The Cape Verdean authorities have placed particular emphasis on promoting the} country's economic and social development through the expansion of its traditionally very narrow export base. In order to succeed in selling goods and services "made in Cape Verde" on foreign markets and, subsequently, in increasing the country's prosperity over the longer term, a large fraction of the export growth needed to be quality rather than price diviven. The study of several international competitiveness indicators-real exchange rates, wage-price developments, international market shares-appears to reinforce the appropriateness of the government 's development approach. While the international price competitiveness indicators showed some deterioration in 1996 and 1997, they have receded to their long-run averages in 1998. Furthermore, Cape Verdean exporters, with diversified products, managed to double their world market share during the period 1993-97.

\section{INTRODUCTION}

58. With the adoption of the National Development Plan 1997-2000 (NDP), the authorities in Praia have sought to overcome their country's structural weaknesses by means of liberalizing its trade to accomplish - as the document's subtitle insinuates- "Cape Verde's dynamic insertion into the world economy." The economic reforms delineated in this policy blueprint were designed to raise Cape Verdeans' standards of living within the constraints of maintaining both the economy's internal and external balances. Subsequently (to secure increases in productivity and, ultimately, prosperity), the government placed considerable importance on reform policies that would broaden the country's traditionally narrow export base. This emphasis was crucial, given the authorities' decision to impose the rigidities and discipline of a nominal, single-currency exchange rate peg on their economy. Hence, the ultimate success of the government's comprehensive reform program hinges on the consistent improvement of Cape Verde's international competitiveness. This chapter will review the indicators and assess whether some progress has been made in achieving this goal.

59. Several authors-most notably Krugman (1994 and 1996)-have stressed the complexity, if not impossibility, of applying the competitiveness concept to countries as a whole, a viewpoint that has been justified mainly by the argument that countries have no independent utility functions of their own. Firms' objectives, by contrast, are easily quantifiable, and an ensuing, but misplaced analogy of the competition among firms and nations has, according to this argument, led to inappropriate policies. However, approaching the competitiveness concept - analogous to the utility axiom-as the analysis of the factors that (1) are amenable to being influenced by economic policy and (2) affect the economic performance of export-oriented businesses, it is possible to-at least-qualitatively argue whether an economic environment, in which these firms operate, has become more favorable for the purpose of generating export revenues. The problems of absolute competitiveness comparisons among nations could thus be circumvented. And, depending on whether the 
changes in the underlying factors are price or quality driven, some indications can be derived as to the temporary or permanent nature of the changes to a country's competitive environment.

60. Notwithstanding the fact that there is no generally accepted definition (never mind a single indicator), which would capture the very essence of "international competitiveness," this chapter tries to obtain some insights into the development of Cape Verde's ability to generate earnings from the export of goods and nonfactor services to foreign markets by analysing several definitions of complementary variables affecting the country's external competitiveness. The structure, in which the forthcoming argument will be presented, is influenced by the NDP's introductory statement, according to which the plan's economic policies are driven by the long-run objective of ensuring the "self-sustained economic and social development" of Cape Verde. As a result, the evaluation of Cape Verde's evolving competitiveness will be decomposed into the study of variables affecting (1) the internal balance (i.e., minimal unemployment at a given level of inflation), (2) the external one (i.e., the realization of a sustainable current account balance), and (3) the gains in productivity and international market shares.

\section{The ANalytical Framework}

61. As has been argued on various occasions (see, for instance, Corden (1994) and Bolthc (1996)), the economic variables subsumed under (1) and (2) could stand in a relationship of tension with those in (3). An "overly competitive" situation stemming from advantages in terms of declining unit labor costs-in itself or relative to countries with "competing" industries - or depreciating real effective exchange rates can usually only be maintained in the short term. The continuous pursuit of labor cost- and/or exchange rate-suppressing policies is hampered by their declining marginal benefits and increasing marginal costs (both in terms of domestic purchasing power and inflationary pressures). Moreover, if these policies are employed repeatedly, they become detrimental to the long-run goal of rising living standards. Inversely, policies aimed at protecting an "uncompetitive" environment are counter-productive as well. These exist, either if a full-employment economy runs unsustainably large current-account deficits (which, eventually, would lead to situations requiring the devaluation of the local currency and the concomitant pursuit of tighter monetary and/or fiscal policies) or if governments continue to defend an "overvalued" exchange rate. The latter policies would lead, if ineffective, to financial crises or, if sustained, to the permanent loss of markets, declining international market shares, and rising unemployment rates.

62. Consequently, as a first step into the analysis of Cape Verde's evolving competitiveness, the study will touch on the discussion of the adequacy of the country's exchange rate peg. While being a useful tool, international price competitiveness indicators - as has been argued, for instance, by Turner and Golub (1997)-are insufficient for a concluding assessment of the appropriate exchange rate level, mainly because of the 
statistics' a priori abstraction from any nonprice (i.e., productivity or quality) aspects, which also affect a country's ability to sell its products in foreign markets. ${ }^{32}$ However, as a "preliminary" step and complementary tool, the analysis of the relative price changes is meaningful and will be undertaken in Section III. It considers both the real exchange rates and the wage-price developments characterizing Cape Verde's labor market. Its results will form the basis for the subsequent discussion of the possible productivity gains measured in terms of the country's capacity to produce higher-quality products (Section IV). This had been an explicit goal set out in the NDP when promoting policies aimed at fostering Cape Verde's "self-sustained economic and social development." ${ }^{33}$ For more specialized, higherquality products, the pertinent price elasticities of demand decrease, thus leading to a reduced variability in export volumes in times of rising relative prices and, consequently, to an overall terms-of-trade improvement. Such a development is pivotally important for any country that attempts to escape the need for continuously declining real wage and exchange rates. To account for quality driven improvements in competitiveness, international trade patterns and long-term shifts in market shares will be included in the competitiveness analysis. Concluding comments will be made in Section V.

\section{Measures of International Price and Relative Cost Competitiveness}

63. The dramatic changes to the global trade regime that have occurred during the 1990s have led to an increase of "competition" among countries seeking the establishment of trade relations and foreign direct investment. The extraordinary innovations in the information technology sector that enabled firms to instantaneously transmit data and documents very inexpensively have accelerated the degree of business mobility, which had already been expedited by the emergence of large free-trade zones, the deregulation of air travel, and the low-wage competition from recently industrialized economies. In the wake of corporations' supranational approaches to production and distribution, global business and investment opportunities have become a function of exchange rates, wage levels, taxes, regulations, and other non-economic factors. Given the considerable improvements to Cape Verde's structural

\footnotetext{
${ }^{32}$ A real appreciation could stem from a relative increase in the demand for domestic goods, reflecting, for instance, an improvement of the products' quality, or simply point towards an overvaluation of a country's currency. For a comprehensive discussion of competitiveness indicators as a tool for the assessment of the appropriateness of exchange rate levels, see also Artus and Knight (1984).

${ }^{33}$ In a recent publication, the Organization of Economic Development and Cooperation has - in an attempt to capture both the price and productivity elements-proposed a "working definition of national competitiveness" that appears particularly applicable for the present purpose. "Competitiveness for a nation," according to this definition, "is the degree to which it can, under free and fair market conditions, produce goods and services that meet the test of international markets while simultaneously maintaining and expanding the real income of its people" (OECD, 1992, p. 242).
} 
Figure 7. Cape Verde: Composition of Exports, 1988-98

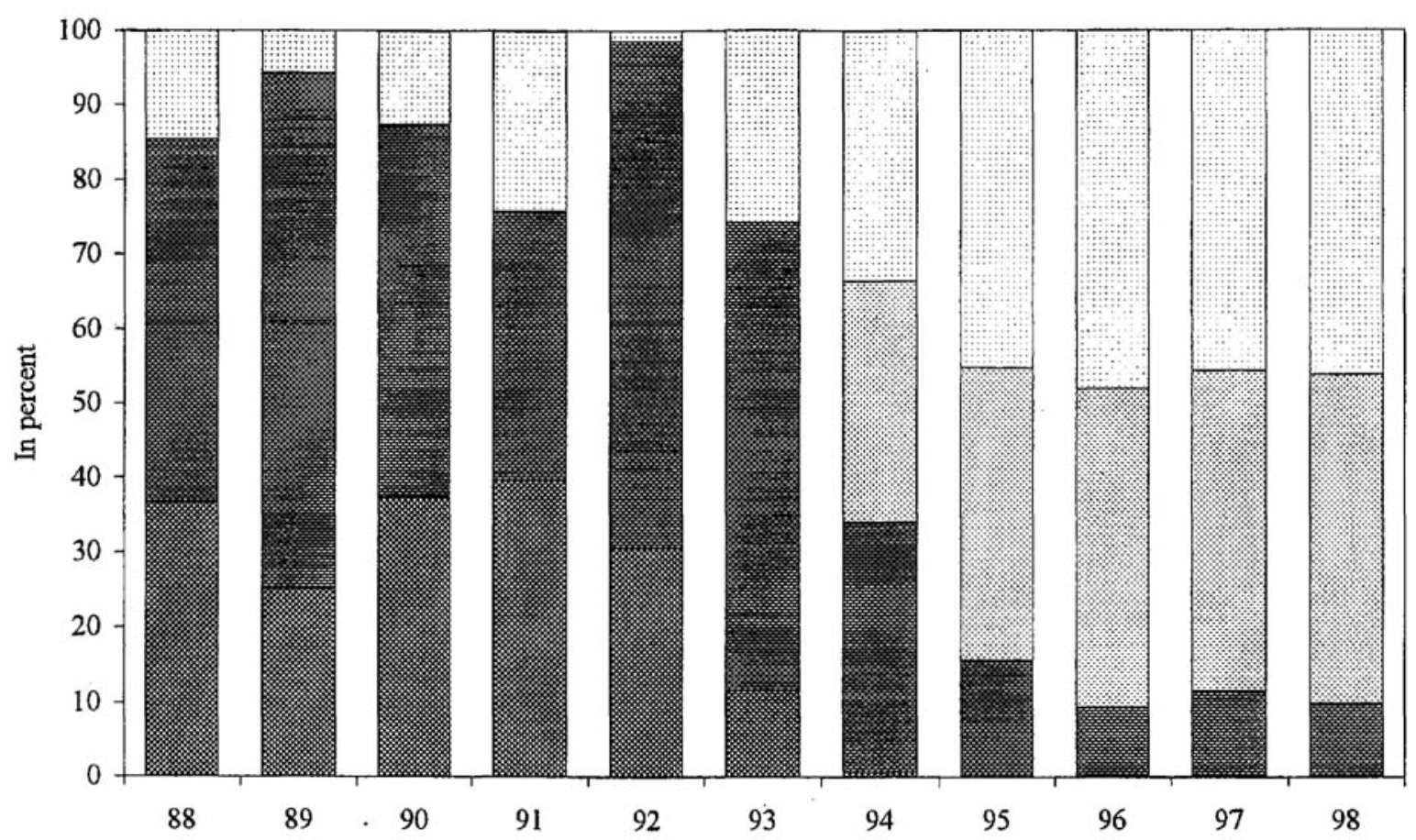

Agricultural products Fish and crustacean 1 Shoes, shoe parts, and clothing $\square$ Other products

Sources: Cape Verdean authorities; and staff estimates.

superstructure-in terms of property rights, tax incentives, and exchange rate policies-price considerations have marginally gained in the importance as key parameters deciding on Cape Verde as a country of business and investment.

\section{A. The Composition and Destination of Exports}

64. Figure 7 shows the degree to which the structural reforms that substantiated the process of trade liberalization have already led to a fundamental change in Cape Verdean sales to foreign markets, both in terms of composition and destination. Its firms managed to increasingly sell goods produced in the secondary sector-particularly shoes, shoe parts, and clothes. Correspondingly, the exports of fish, crustaceans, and agricultural products haveboth in relative and absolute terms-decreased. At the beginning of the decade, the primary sector exports represented close to nine-tenth of overall shipments abroad (excluding fuel reexports), at the end of it, they shrunk to about one-tenth. The process of export diversification-also reflected in the evolving composition of the countries of export destination-signifies the progress that has already been made by the authorities in expanding its economy's productive base. Both Tables 1 (with data originating from the statistical bureaus of the respective export-destination countries) and 35 (with data provided by the Cape Verdean authorities) and show relatively stable trade relations with developing 
Table 1. Cape Verde: Destination of Exports, 1988-97

\begin{tabular}{|c|c|c|c|c|c|c|c|c|c|c|}
\hline & 1988 & 1989 & 1990 & 1991 & 1992 & 1993 & 1994 & 1995 & 1996 & 1997 \\
\hline & \multicolumn{10}{|c|}{ (In millions of U.S. dollars) } \\
\hline World & 7 & 7 & 7 & 6 & 13 & 13 & 7 & 15 & 19 & 21 \\
\hline Industrial countries & 3 & 6 & 7 & 5 & 6 & 9 & 6 & 10 & 15 & 17 \\
\hline European Union & 3 & 4 & 7 & 5 & 6 & 3 & 5 & 10 & 15 & 17 \\
\hline Of which: Portugal & 2 & 2 & 2 & 3 & 3 & 2 & 3 & 7 & 10 & 10 \\
\hline Others & 0 & 2 & 0 & 0 & 1 & 6 & 1 & 1 & 1 & 1 \\
\hline \multirow[t]{2}{*}{ Developing countries } & 4 & 1 & 0 & 1 & 6 & 4 & 1 & 4 & 3 & 3 \\
\hline & \multicolumn{10}{|c|}{ (In percent) } \\
\hline World & 100 & 100 & 100 & 100 & 100 & 100 & 100 & 100 & 100 & 100 \\
\hline Industrial countries & 43 & 86 & 100 & 83 & 46 & 69 & 86 & 67 & 79 & 81 \\
\hline European Union & 43 & 57 & 100 & 83 & 46 & 23 & 71 & 67 & 79 & 81 \\
\hline Of which: Portugal & 29 & 29 & 29 & 50 & 23 & 15 & 43 & 47 & 53 & 48 \\
\hline Others & 0 & 29 & 0 & 0 & 8 & 46 & 14 & 7 & 5 & 5 \\
\hline Developing countries & 57 & 14 & 0 & 17 & 46 & 31 & 14 & 27 & 16 & 14 \\
\hline
\end{tabular}

Source: IMF's Direction of Trade Statistics.

countries and an expanding trend towards exporting goods to industrial countries (and among them, particularly, to Portugal and the other members of the European Union). ${ }^{34}$

\section{B. Estimates of the Real Exchange Rate}

65. The particularity in Cape Verde's trade pattern makes the analysis of two definitions of international price competitiveness especially interesting - the traditional trade-weighted real effective exchange rate as well as the development of the real exchange rate vis-à-vis the Portuguese escudo. ${ }^{35}$ While the former relationship reflects overall changes in relative prices,

34 The difference in export values is largely the result of the different treatment by the Cape Verdean and foreign statistical bureaus of the fuel reexports to foreign ships and aircraft.

${ }^{35}$ The real exchange rate, $\varepsilon$, is defined as $(e p)^{f} p^{-1}$, where $e$ is the nominal exchange rate (measured as foreign currency per unit of domestic currency), and $p$ and ${ }^{f} p$ the domestic and foreign price levels, respectively. In the case of the real effective exchange rate, $e$ and ${ }^{f} p$ are the weighted averages of bilateral nominal exchange rates and the foreign trading partners' prices, respectively. Since competitiveness is thus defined in terms of the relative price of continued 
the latter one signifies the development of Cape Verde's price (dis-)advantages vis-à-vis its main market and allows for some preliminary conclusions about the current exchange rate peg.

66. Figure 8 shows that the real effective exchange rate, between 1990 and 1996, was relatively constant, with very rare oscillations beyond a \pm 5 percent range from its 1990 average. In 1997, however, it deteriorated considerably, partly in reaction to the government's difficulty in controlling fiscal spending (with the corresponding consequences on prices, reserves, and investors' confidence; see main text). By mid-1997, the real exchange rate had appreciated far beyond the band within which it had previously fluctuated. Fiscal and monetary tightening in 1998, the nominal devaluation of 6 percent vis-à-vis a currency basket in end-March 1998, and the switch to a single-currency peg with the Portuguese escudo in early July 1998 seem to have proven sufficient to bring the real exchange rate back towards its long-run average. In more recent developments, the inflationary blip in the final quarter of 1998 (see Chapter II, Section C in the main text)-as well as its receding in early 1999-are clearly visible in the real exchange rate charts, signifying an overall return to its long-run trend.

67. Despite some variability in the bilateral rates, Cape Verde's international price competitiveness vis-à-vis its main trading partner showed an improving trend during the 1990-96 period. Apart from the reasons given above, the relatively more pronounced deterioration of Cape Verde's bilateral price competitiveness in 1997 largely reflected Portugal's fiscal pre-Maastricht adjustment program. ${ }^{36}$ While the one-year lag between Cape Verde's fiscal consolidation (which started in 1998) and the one pursued by all the future member countries of the euro zone ${ }^{37}$ represents the most important explanation behind the considerable real exchange rate deterioration in 1997, but it also serves as an important

foreign goods in terms of domestic goods, a decrease in the indicator represents an improvement in competitiveness.

${ }^{36}$ Portugal, which supports Cape Verde's exchange-rate peg with the Portuguese escudo (and its successor currency) through a precautionary credit facility-jointly managed by both governments through the Commissão do Accordo de Cooperação Cambial (COMACC)—has accordingly requested that Cape Verde adhere to the so-called Maastricht criteria.

${ }^{37}$ The currency basket determining the real effective exchange rate is, to almost 78 percent, comprised of euro predecessor currencies. The Portuguese escudo represents 41 percent, the French franc 9.4 percent, the Dutch guilder 7.6 percent, the Deutsche mark 7.3 percent, the Spanish peseta 6.2 percent, the Italian lira 3.6 percent, and the Belgian franc 2.8 percent. The remaining currencies are the ones of the United States (5.8 percent), Japan (5.1 percent), the United Kingdom ( 5 percent), Sweden ( 2.8 percent), Canada (1.9 percent), and China (1.5 percent). 
Figure 8. Cape Verde: Real Effective Exchange Rates, January 1990 - February 1999

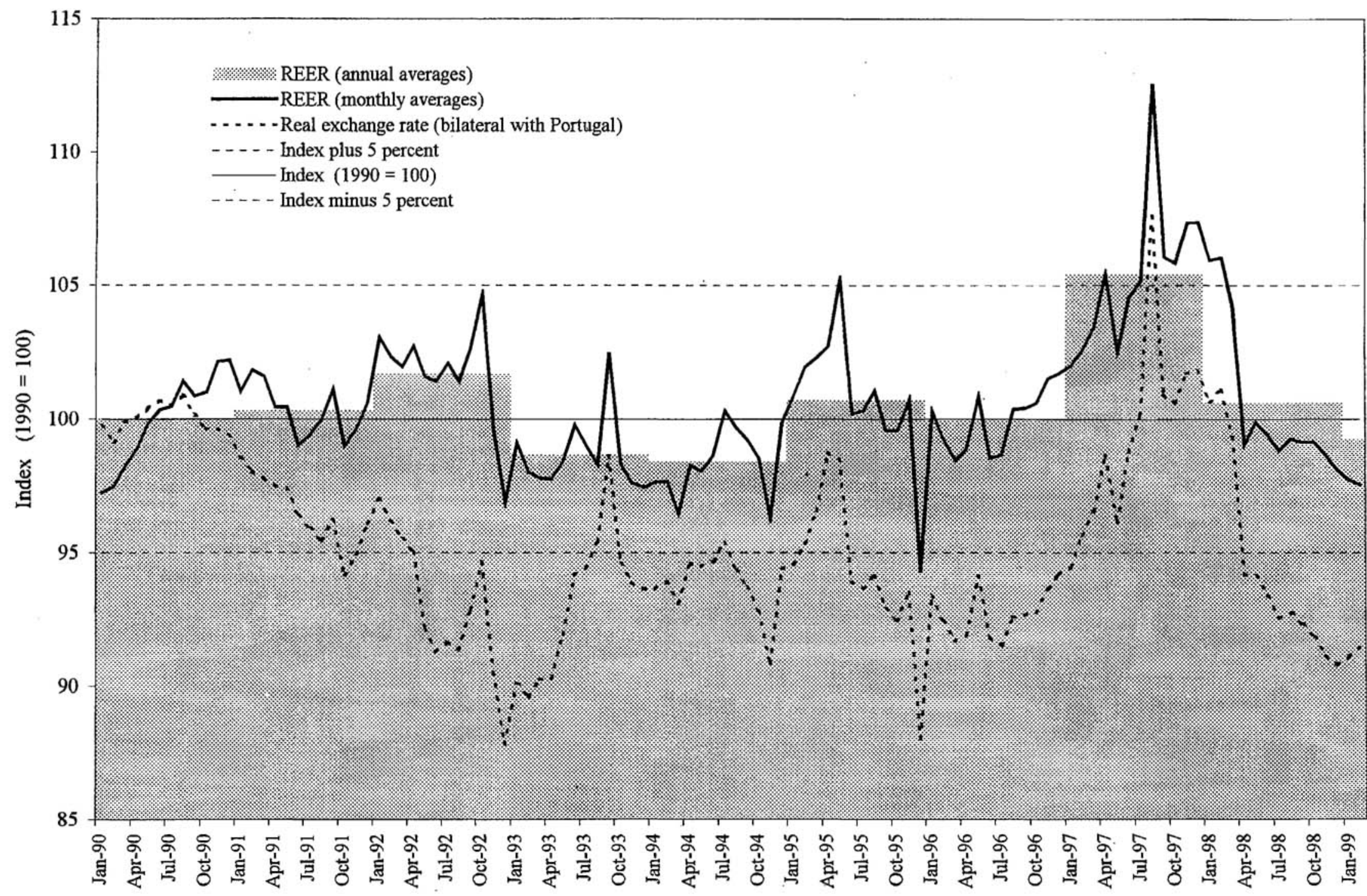


reminder that the Cape Verdeans' fiscal space of manoeuvre has shrunk as a result of the currency peg with the Portuguese escudo (and its successor currency) in mid-1998.

\section{Recent Wage Developments in Cape Verde}

68. The main economic among the various other factors inducing foreign companies to invest in Cape Verde are-next to the country's political stability and its comparatively large degree of social tranquility - the relatively low labor costs. Still, these typically represent the largest domestic cost component of inward investments and thus are closely observed by potential investors, even more so in view of the advanced stage of the country's accelerated privatization program (see Box 5 in the main text). As shown in both Figure 9 and Table 2, wage levels have fluctuated considerably during the seven-year transition period from the central plan to its current market-based framework. The initial volatility in the real wages determined by the new free market environment has started to subside (in about 1997) - with a far greater degree of uniformity across the various professions and more gradual adjustments in remuneration. The instability of relative wages during 1991-96 mirrors the evolution of the economy's stagnant and dynamic sectors described in the main text's Chapter II. The real wages in the expanding sectors (construction and services) have experienced significant rises-during the period 1990-98, they about doubled for bricklayers, master carpenters, painters as well as for servants and store manager-while those in stagnant sectors and among low-skill occupations tended to decline (e.g., diggers, workers, clerks, and car drivers).

69. During the latter half of the 1990s, average real wages have, however, increased steadily, in 1996 and 1997 even considerably, resulting in a modest erosion of Cape Verde's price competitiveness. ${ }^{38}$ By contrast, real wages stagnated or even declined in 1998 (with the notable exceptions of those paid to bricklayers, mechanics, painters, and pavers), indicating that the decline of Cape Verde's wage price competitiveness has, at least, been stopped, if not reversed. The countercyclical wage price movements of the aforementioned "boom" professions reflect the high demand for construction-related personnel. Given that these are part of the nontradable sectors of the economy, their influence on Cape Verde's relative price competitiveness remained limited.

\section{Measures of Relative Productivity and INTERnational MaRket ShaRes}

70. Notwithstanding the absence of large advantages in price competitiveness, Cape Verde's exports showed a remarkable trend increase, both in absolute and relative terms. As described in the main text's Chapter V, the export realizations in 1998 were impeded by an unfortunate series of exogenous-and likely temporary-shocks such as (1) the unusually cold waters reducing the stock of fish and crustaceans in its fishing grounds, (2) expansion

${ }^{38}$ Increases of wages paid in the public sector, adjusted for consumer prices, have steadily declined after 1994 (Table 13) 
Table 2. Level of Monthly Wages by Occupation, 1990-98

\begin{tabular}{|c|c|c|c|c|c|c|c|c|c|}
\hline & 1990 & 1991 & 1992 & 1993 & 1994 & 1995 & 1996 & 1997 & 1998 \\
\hline & \multicolumn{9}{|c|}{ (In U.S. dollars) } \\
\hline Baker & 108.2 & 174.7 & 281.9 & 100.5 & 98.7 & 110.0 & 139.8 & 126.4 & 120.0 \\
\hline Bricklayer & 120.7 & 133.6 & 220.8 & 146.2 & 143.6 & 142.8 & 205.0 & 247.9 & 313.6 \\
\hline Car driver & 153.7 & 174.7 & 211.2 & 198.2 & 194.6 & 200.2 & 186.3 & 189.9 & 188.2 \\
\hline Carpenter & 131.0 & 162.1 & 220.8 & 183.5 & 180.3 & 200.2 & 186.3 & 173.8 & 169.6 \\
\hline Carpenter's assistant & 70.9 & 69.6 & 81.5 & 82.7 & 97.3 & 105.2 & 111.9 & 111.6 & 110.6 \\
\hline Cashier (cornmerce) & 199.9 & 275.0 & 324.3 & 274.3 & 269.4 & 250.4 & 251.7 & 306.2 & 297.8 \\
\hline Clerk & 299.5 & 355.8 & 435.7 & ... & $\ldots$ & 360.7 & 247.0 & 225.6 & 214.1 \\
\hline Digger & 89.1 & 87.3 & 107.3 & 90.8 & 89.1 & 105.2 & 111.9 & 116.5 & 118.1 \\
\hline Foreman & 124.7 & 122.3 & 166.4 & 140.7 & 138.2 & 240.5 & 279.7 & 272.7 & 270.5 \\
\hline Kneader & 64.3 & 67.9 & 71.3 & 72.4 & 93.1 & 105.2 & 134.8 & 124.0 & 124.7 \\
\hline Locksmith & 171.5 & 168.2 & 184.4 & 156.0 & 163.0 & 285.5 & 195.8 & 185.9 & 188.7 \\
\hline Master carpenter & 131.0 & 143.6 & 173.2 & $\ldots$ & $\ldots$ & 225.4 & 223.8 & 285,1 & 352.9 \\
\hline Master mason & 161.6 & 197.3 & 350.8 & $\ldots$ & $\ldots$ & 240.5 & 326.1 & 357.0 & 338.7 \\
\hline Mechanic & 219.7 & 228.7 & 284.6 & 240.7 & 239.2 & 285.5 & 223.8 & 224.6 & 250.8 \\
\hline Painter & 90.0 & 124.5 & 242.1 & 215.4 & 225.9 & 180.3 & 186.3 & 198.3 & 215.5 \\
\hline Paver & 64.3 & 63.1 & 93.7 & 85.6 & 93.4 & 110.0 & 111.9 & 124.7 & 142.8 \\
\hline Porter & $\ldots$ & $\ldots$ & $\ldots$ & 70.9 & 77.9 & 0.0 & 111.9 & 124.5 & 124.7 \\
\hline Sales clerk (commerce) & 157.3 & 178.9 & 214.0 & 180.9 & 177.7 & 200.5 & 195.8 & 181.0 & 175.2 \\
\hline Servant & 33.0 & 48.5 & 50.9 & 57.4 & 65.7 & 90.2 & 139.8 & 128.9 & 129.4 \\
\hline Store assistant (commerce) & 87.1 & 131.3 & 189.8 & $\ldots$ & $\ldots$ & 250.4 & 234.9 & 210.0 & 199.9 \\
\hline Store head (commerce) & 155.0 & 280.1 & 326.0 & 275.7 & 270.8 & 300.6 & $\$ 12.7$ & 471.0 & 465.8 \\
\hline Street sweeper & 46.2 & 58.2 & 61.1 & 57.4 & 60.9 & $\ldots$ & $\ldots$ & $\ldots$ & ... \\
\hline \multirow[t]{2}{*}{ Worker } & 92.7 & 125.2 & 131.4 & $\ldots$ & $\ldots$ & 135.3 & 139.8 & 124.0 & 124.7 \\
\hline & \multicolumn{9}{|c|}{ (In 1990's Cape Verde escudos) } \\
\hline Baker & 7,577 & 11,594 & 15,709 & 6,260 & 6,055 & 5,840 & 7,529 & 7,074 & 6,777 \\
\hline Bricklayer & 8,455 & 8,867 & 12,302 & 9,104 & 8,805 & 7,579 & 11,038 & 13,870 & 17,713 \\
\hline Car driver & 10,765 & 11,594 & 11,772 & 12,342 & 11,936 & 10,627 & 10,029 & 10,625 & 10,630 \\
\hline Carpenter & 9,171 & 10,757 & 12,302 & 11,429 & 11,054 & 10,627 & 10,029 & 9,723 & 9,581 \\
\hline Carpenter's assistant & 4,967 & 4,616 & 4,542 & 5,151 & 5,968 & 5,585 & 6,023 & 6,242 & 6,245 \\
\hline Cashier (conmerce) & 13,999 & 18,250 & 38,075 & 17,082 & 16,520 & 13,292 & $.13,553$ & 17,130 & 16,823 \\
\hline Clerk & 20.975 & 23,618 & 24,283 & $\ldots$ & $\ldots$ & 19,148 & 13,297 & 12,622 & 12,092 \\
\hline Digger & 6,237 & 5,797 & 5,981 & 5,652 & 5,466 & 5,585 & 6,023 & 6,519 & 6,671 . \\
\hline Foreman & 8,732 & 8,116 & 9,274 & 8,764 & 8,476 & 12,765 & 15,059 & 15,257 & 15,281 \\
\hline Kneader & 4,505 & 4,509 & 3,975 & 4,507 & 5,709 & 5,585 & 7,258 & 6,935 & 7,043 \\
\hline Locksmith & 12,012 & 11,165 & 10,277 & 9,712 & 9,999 & 15,159 & 10,541 & 10,403 & 10,657 \\
\hline Master carpenter & 9,171 & 9,533 & 9.653 & $\ldots$ & $\ldots$ & 11,968 & 12,047 & 15,951 & 19,932 \\
\hline Master mason & 11,319 & 13,097 & 19,551 & $\ldots$ & $\ldots$ & 12,765 & 17,558 & 19,973 & 19,135 \\
\hline Mechanic & 15,385 & 15,180 & 15,860 & 14,989 & 14,670 & 15,159 & 12,047 & 12,567 & 14,165 \\
\hline Painter & 6,306 & 8,266 & 13,495 & 13,415 & 13,856 & 9,574 & 10,029 & 11,096 & 12,172 \\
\hline Paver & 4,505 & 4,187 & 5,224 & 5,330 & 5,726 & 5,840 & 6,023 & 6,977 & 8,066 \\
\hline Porter & $\ldots$ & $\ldots$ & $\ldots$ & 4,418 & 4,775 & $\ldots$ & 6,023 & 6,963 & 7,043 \\
\hline Sales clerk (commerce) & 11,019 & 11,873 & 11,924 & 11,269 & 10,898 & 10,643 & 10,541 & 10,125 & 9,900 \\
\hline Servant & 2,310 & 3,221 & 2,839 & 3,577 & 4,031 & 4,787 & 7,529 & 7,213 & 7,308 \\
\hline Store assistant (commerce) & 6,098 & 8,717 & 10,580 & $\ldots$ & $\ldots$ & 13,292 & 12,649 & 11,748 & 11,295 \\
\hline Store head (commerce) & 10,857 & 18,594 & 18,169 & 17,171 & 16,607 & 15,957 & 27,603 & 26,354 & 26,310 \\
\hline Street sweeper & 3,234 & 3,865 & 3,407 & 3,577 & 3,737 & $\ldots$ & $\ldots$ & $\ldots$ & $\ldots$ \\
\hline \multirow[t]{2}{*}{ Worker } & 6,491 & 8,309 & 7,325 & $\ldots$ & $\ldots$ & 7,181 & 7,529 & 6,935 & 7,043 \\
\hline & \multicolumn{9}{|c|}{ (Real-wage index: $1990=100$ ) } \\
\hline Baker & 100.0 & 153.0 & 207.3 & 82.6 & 79.9 & 77.1 & 99.4 & 93.4 & 89.4 \\
\hline Bricklayer & 100.0 & 104.9 & 145.5 & 107.7 & 104.3 & 89.6 & 130.6 & 164.1 & 209.5 \\
\hline Car driver & 100.0 & 107.7 & 109.4 & 114.7 & 110.9 & 98.7 & 93.2 & 98.7 & 98.8 \\
\hline Carpenter & 100.0 & 117.3 & 134.1 & 124.6 & 120.5 & 115.9 & 109.4 & 106.0 & 104.5 \\
\hline Carpenter's assistant & 100.0 & 92.9 & 91.5 & 103.7 & 120.2 & 112.5 & 121.3 & 125.7 & 125.7 \\
\hline Cashier (commerce) & 100.0 & 130.4 & 129.1 & 122.0 & 118.0 & 95.0 & 96.8 & 122.4 & 120.2 \\
\hline Clerk & 100.0 & 112.6 & 115.8 & $\ldots$ & $\ldots$ & 91.3 & 63.4 & 60.2 & $\$ 7.7$ \\
\hline Digger & 100.0 & 92.9 & 95.9 & 90.6 & 87.6 & 89.5 & 96.6 & 104.5 & 107.0 \\
\hline Foreman & 100.0 & 92.9 & 106.2 & 100.4 & 97.1 & 146.2 & 172.5 & 174.7 & 175.0 \\
\hline Kneader & 100.0 & 100.1 & 88.2 & 100.1 & 126.7 & 124.0 & 161.1 & 154.0 & 156.3 \\
\hline Locksmith & 100.0 & 92.9 & 85.6 & 80.9 & 83.2 & 126.2 & 87.8 & 86.6 & 88.7 \\
\hline Master carpenter & 100.0 & 104,0 & 105.3 & $\ldots$ & $\ldots$ & 130.5 & 131.4 & 173.9 & 217.3 \\
\hline Master mason & 100.0 & 115.7 & 172.7 & $\ldots$ & $\ldots$ & 112.8 & 155.1 & 176.5 & 169.0 \\
\hline Mechanic & 100.0 & 98.7 & 103.1 & 97.4 & 95.4 & 98.5 & 78.3 & 81.7 & 92.1 \\
\hline Painter & 100.0 & 131.1 & 214.0 & 212.7 & 219.7 & 151.8 & 159.0 & 176.0 & 193.0 \\
\hline Paver & 100.0 & 92.9 & 116.0 & 118.3 & 127.1 & 129.7 & 133.7 & 154.9 & 179.1 \\
\hline Porter & $\ldots$ & $\ldots$ & $\ldots$ & $\ldots$ & $\ldots$ & $\therefore$ & $\ldots$ & $\ldots$ & $\ldots$ \\
\hline Sales clerk (comrnerce) & 100.0 & 107.8 & 108.2 & 102.3 & 98.9 & 96.6 & 95.7 & 91.9 & 89.8 \\
\hline Servant & 100.0 & 139.4 & 122.9 & 154.9 & 174.5 & 207.2 & 325.9 & 312.2 & 316.4 \\
\hline Store assistant (commerce) & 100.0 & 142.9 & 173.5 & 0.0 & 0.0 & 218.0 & 207.4 & 192.6 & 185.2 \\
\hline Store head (commerce) & 100.0 & 171.3 & 167.4 & 158.2 & 153.0 & 147.0 & 254.2 & 242.7 & 242.3 \\
\hline Worker & 100.0 & 128.0 & 112.8 & ,.. & $\ldots$ & 110.6 & 116.0 & 106.8 & 108.5 \\
\hline
\end{tabular}


Figure 9. Cape Verde: Real Annual Wage Increase by Profession, 1991-98

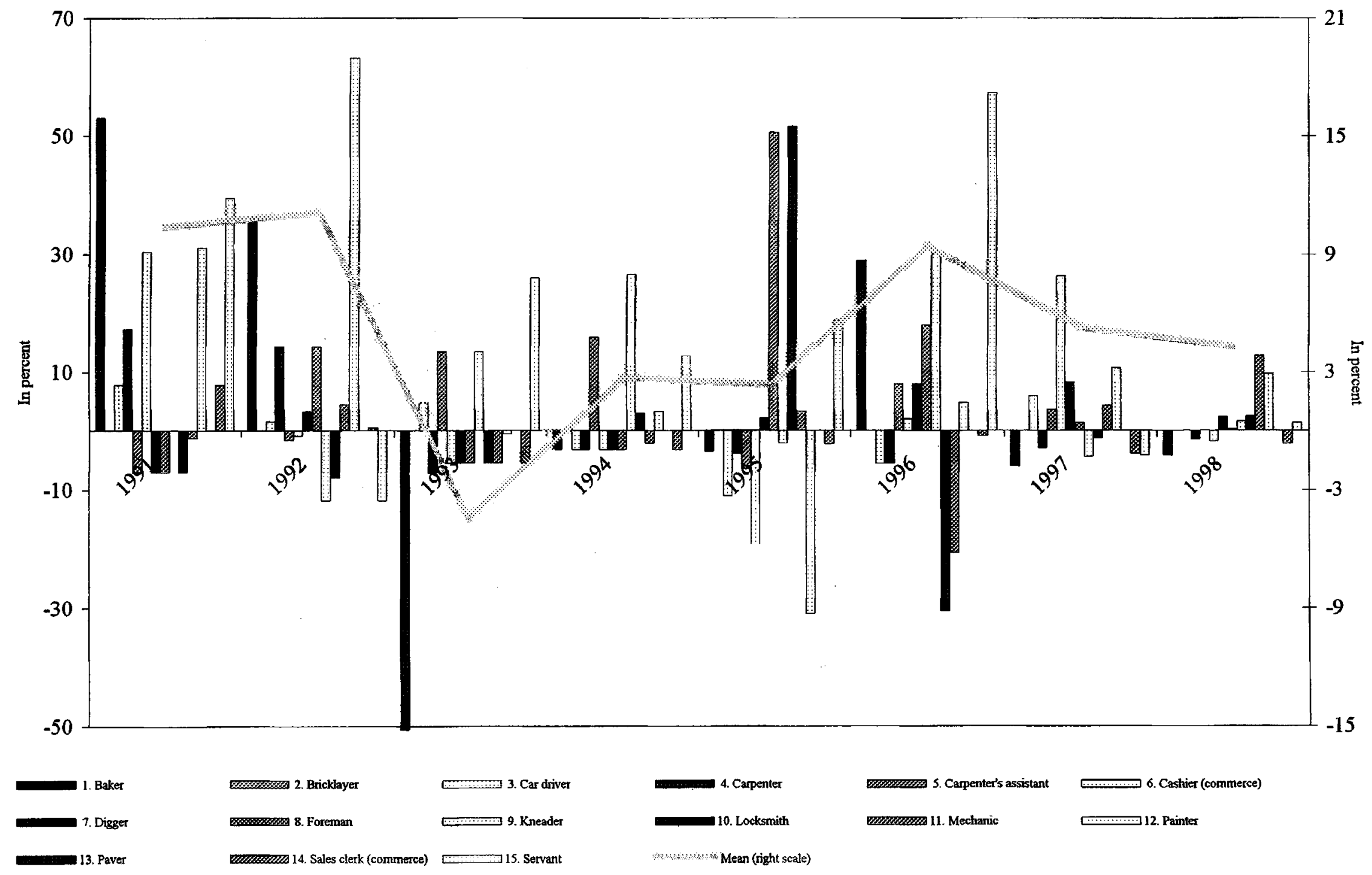


Figure 10. Cape Verde: Relative Export Performance, 1986-98

Exports as a Share of GDP and of World Exports

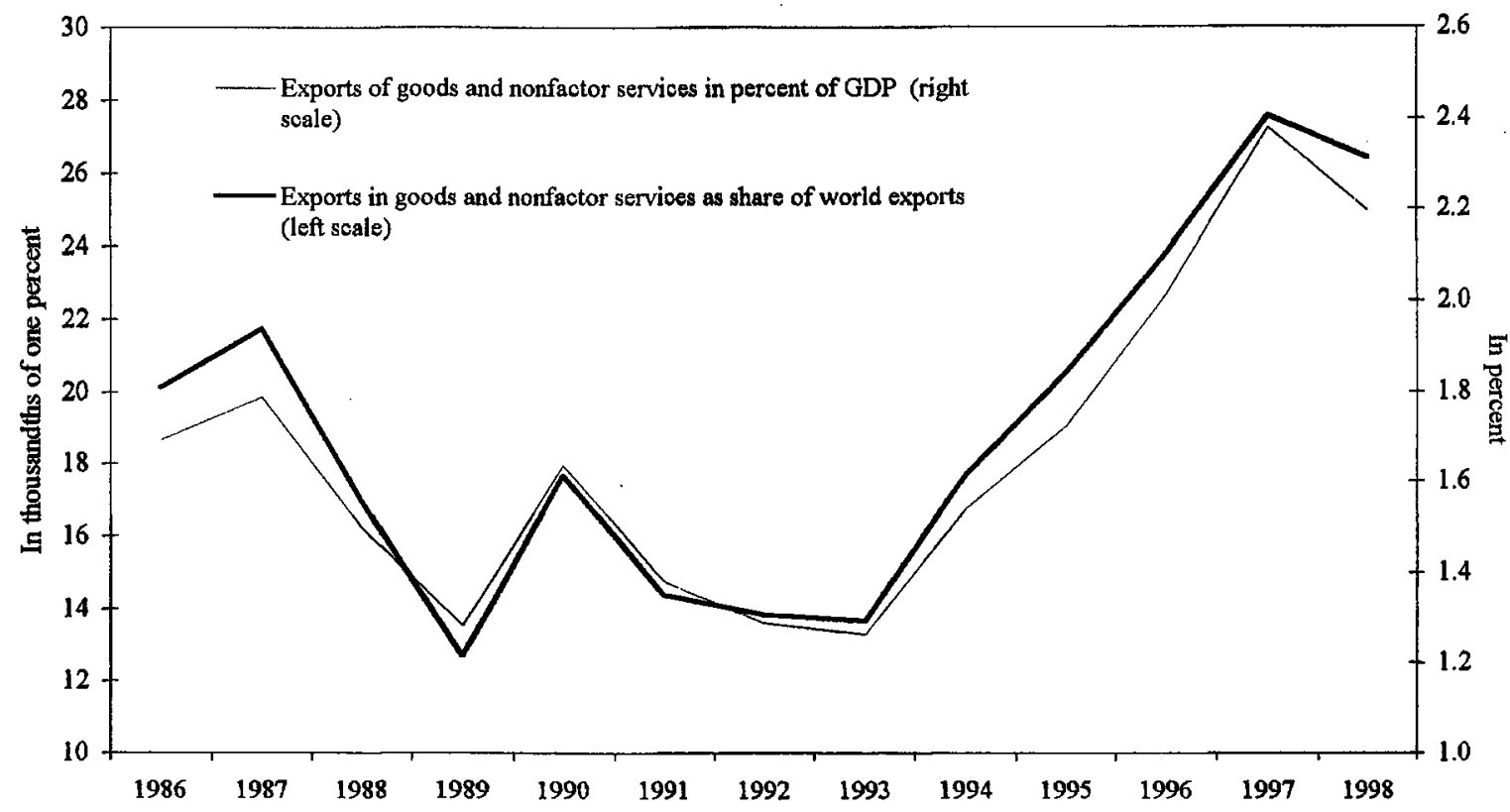

Annual Changes in Exports and Imports

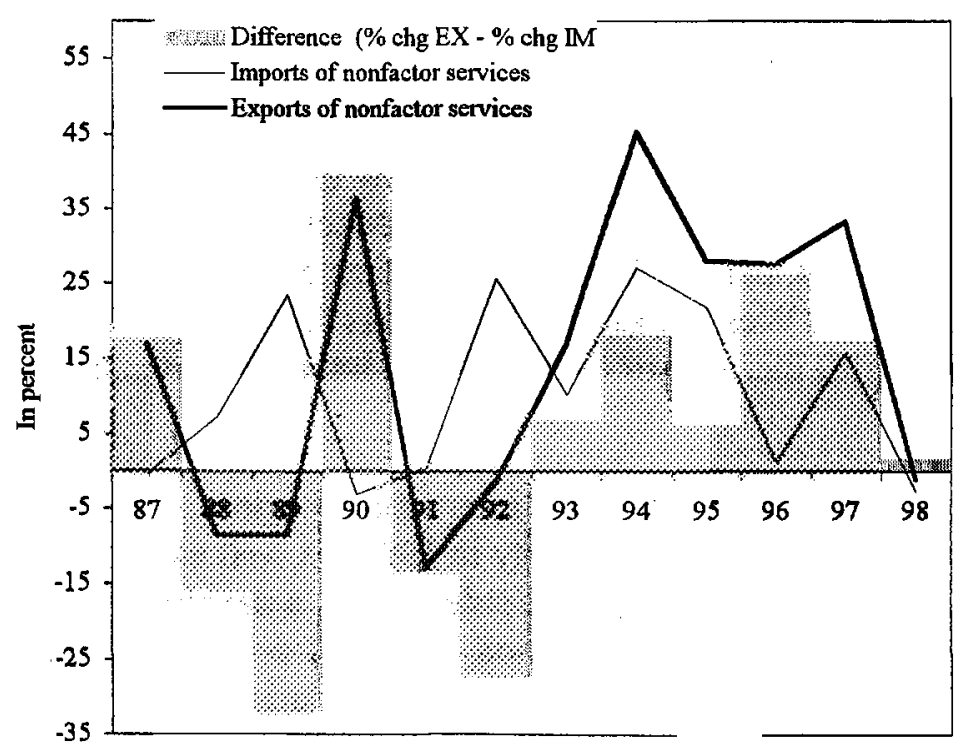

Exports of Goods and Nonfactor Services in

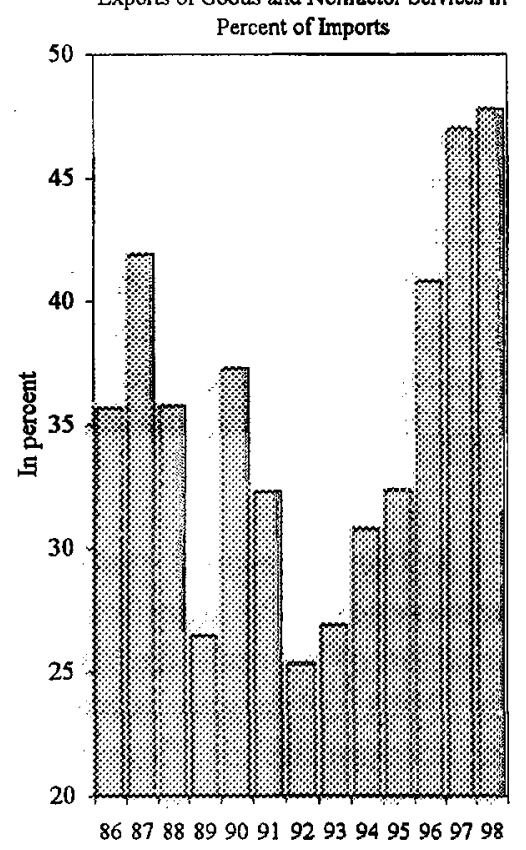

Sources: Cape Verdean authorities; MMF's Direction of Trade Statistics; and staff estimates. 
related interruptions in the production export-oriented goods, (3) declining fuel reexports following a neighboring country's civil war, (4) an important airline's cancellation of flights to and from Sal, and (5) a severe drought destroying a large part of its agricultural harvest.

71. Figure 10 shows that in every years since 1991 , the growth rates in the export of goods and nonfactor services exceeded the corresponding figure for imports (see also Tables 30-34). Consequently, the sales of goods and services consistently pay for a larger fraction of imports, with its value having increased from about a quarter in 1992 to almost one half in 1997 and 1998-despite the uniquely difficult situation in 1998.

72. The clearest indication of the increasing quality of Cape Verdean products is its performance relative to other countries. Between 1993 and 1997, its firms doubled the international market share, from about 14 one-thousandth of one percent to 28 onethousandth of one percent of world exports. The country's share of world exports, therefore, not only exceeds its share of world population (about 8 one-thousandth of one percent), but it also highlights the dynamism in the development of viable private sector production in Cape Verde. Exports of goods and nonfactor services as a fraction of GDP has almost doubled as well, growing from about 1.2 percent in 1993 to close to 2.4 percent in 1997.

\section{Changes in CaPe Verde's International Competitiveness: A Preliminary Résumé}

73. Cape Verde finds itself in the midst of a comprehensive program of economic decentralization, liberalization, and modernization. Despite the many changes that have occurred and the many difficulties that the authorities encountered en route, the various competitiveness indicators analysed above appear to indicate that Cape Verde has indeed some success in promoting the expansion of its traditionally very narrow export base by means of export diversification and quality increases. This success is reflected in the increasing importance of secondary sector and, particularly, tertiary sector exports, the growing significance of the heavily competed Western European markets as export destinations, as well as the steady (and rapid) increase of Cape Verde's international market share.

74. At the same time, the negative shocks to Cape Verde's international price competitiveness (the significant real wage increases, particularly in 1996, as well as the large appreciation of its real effective exchange rate until the Cape Verde escudo's devaluation in March 1998) had largely subsided by the end of 1998. In addition, the trend decrease in its current account deficit (financed by workers' remittances), decelerating inflation rates, and the increase in net foreign assets of the banking system in 1998-a period, in which the banks paid down about eight-tenths of the foreign exchange queue-indicate that the economy has started to settle into an external equilibrium. Without large additional improvements in relative prices, neither in terms of the real exchange rate nor as a result of declining labor costs, the improvement in Cape Verde's international competitiveness appears to stem from the structural adjustments and the resultant advancements in quality and 
productivity. If substantiated in the coming years, the NDP's goal of securing economic and social development through the promotion of international competitiveness appears attainable, indeed promising for a country long inhibited by substantial structural weaknesses. 


\section{References}

Artus, Jacques R., and Malcolm D. Knight, 1984, Issues in the Assessment of Exchange Rates of Industrial Countries, IMF Occasional Paper No. 29 (July).

Boltho, Andrea, 1996, "The Assessment: International Competitiveness," Oxford Review of Economic Policy 12 (3), 1-16.

Cordon, W. Max, 1994, Economic Policy, Exchange Rates, and the International System (Chicago: The University of Chicago Press).

Krugman, Paul R., 1994, "Competitiveness: A Dangerous Obsession," Foreign Affairs 73 (2), 28-44.

Krugman, Paul R., 1996, "Making Sense of the Competitiveness Debate," Oxford Review of Economic Policy 12 (3), 17-25.

Organization of Economic Coordination and Development, 1992, Technology and the Economy: The Key Relationships (Paris: OECD).

Turner, Anthony G., and Stephen S. Golub, 1997, "Towards a System of Multilateral Unit Labor Cost-Based Competitiveness Indicators for Advanced, Developing, and Transition Economies," IMF Working Paper WP/97/151. 
Table 3. Cape Verde: Sources and Uses of Resources, 1991-98

$\begin{array}{llllllll}1991 & 1992 & 1993 & 1994 & 1995 & 1996 & 1997 & 1998\end{array}$

\begin{tabular}{|c|c|c|c|c|c|c|c|c|}
\hline \multirow[b]{2}{*}{ Gross domestic product } & \multicolumn{8}{|c|}{ (In millions of Cape Verde escudos; unless otherwise indicated) } \\
\hline & 22,806 & 24,353 & 29,215 & 33,641 & 37,864 & 40,638 & 45,101 & 48,667 \\
\hline Percentage change & 5.8 & 6.8 & 20.0 & 15.2 & 12.6 & 7.3 & 11.0 & 7.9 \\
\hline Current account & -623 & -971 & $-3,888$ & $-2,392$ & $-6,360$ & $-5,244$ & $-6,411$ & $-8,122$ \\
\hline Resource balance & $\ldots$ & $\ldots$ & $-10,521$ & $-13,628$ & $-15,081$ & $-13,343$ & $-13,842$ & $-15,557$ \\
\hline Exports of goods and NFS $1 /$ & $\ldots$ & $\ldots$ & 3,878 & 4,976 & 7,218 & 9,211 & 12,286 & 12,139 \\
\hline Imports of goods and NFS $1 /$ & $\ldots$ & $\ldots$ & $-14,399$ & 18,604 & 22,299 & 22,554 & 26,128 & 27,696 \\
\hline Net factor income & 30 & 73 & -300 & -289 & -408 & -557 & -648 & -611 \\
\hline Public sector & -252 & -232 & -240 & $\ldots$ & $\ldots$ & $\ldots$ & $\ldots$ & $\ldots$ \\
\hline Private sector & 282 & 305 & -60 & $\ldots$ & $\ldots$ & $\ldots$ & $\cdots$ & $\ldots$ \\
\hline Unrequited transfers & 5,832 & 8,090 & 6,932 & 11,526 & 9,129 & 8,656 & 8,079 & 8,046 \\
\hline Public sector & 1,706 & 3,338 & 1,245 & 4,911 & 1,476 & 738 & 1,496 & -32 \\
\hline Private sector & 4,126 & 4,752 & 5,687 & 6,614 & 7,653 & 7,918 & 6,584 & 8,078 \\
\hline Gross national product & 22,836 & 24,426 & 28,915 & 33,352 & 37,455 & 40,081 & 44,453 & 48,056 \\
\hline Gross national income & 28,667 & 32,517 & 35,847 & 44,878 & 46,584 & 48,737 & 52,532 & 56,102 \\
\hline \multicolumn{9}{|l|}{ Public sector } \\
\hline Current revenue & 4,025 & 5,010 & 6,307 & 7,099 & 8,405 & 8,575 & 8,773 & $11 ; 656$ \\
\hline Current expenditure (treasury def.) & 4,461 & 4,806 & 5,787 & 6,582 & 8,079 & 7,788 & 8,697 & 8,815 \\
\hline Current expenditure (INE def.) & $\ldots$ & $\ldots$ & 9,721 & 11,922 & 13,456 & 12,939 & 11,407 & 11,317 \\
\hline Capital expenditure (treasury def.) & 3,137 & 7,026 & 8,241 & 10,776 & 10,222 & 10,375 & 8,507 & 8,319 \\
\hline Capital expenditure (INE def.) & $\ldots$ & $\ldots$ & 4,307 & 5,436 & 4,845 & 5,224 & 5,797 & 5,818 \\
\hline Grants & 2,490 & 4,694 & 4,473 & 5,120 & 5,602 & 5,411 & 4,750 & 5,241 \\
\hline Loans & 628 & 1,218 & 1,584 & 1,529 & 1,117 & 1,742 & 650 & 2,086 \\
\hline Domestic & 19 & 1,114 & 2,184 & 2,921 & 2,187 & 1,612 & 2,439 & 0 \\
\hline Of which: privatization & $\ldots$ & $\ldots$ & $\ldots$ & 69 & 1,575 & 2,316 & 1,618 & 0 \\
\hline Gross domestic investment & 6,591 & 9,230 & 11,611 & 14,584 & 14,583 & 15,750 & 17,640 & 19,580 \\
\hline Fixed capital formation & 6,650 & 9,209 & 11,611 & 14,584 & 14,583 & 15,750 & 17,640 & 19,580 \\
\hline Public sector & 3,137 & 7,026 & 4,307 & 5,436 & 4,845 & 5,224 & 5,797 & 5,818 \\
\hline Private sector & 3,513 & 2,183 & 7,303 & 9,149 & 9,738 & 10,526 & 11,842 & 13,762 \\
\hline Change in stocks & -59 & 21 & $\ldots$ & $\ldots$ & $\ldots$ & $\ldots$ & $\ldots$ & $\ldots$ \\
\hline Domeśtic consumption & 16,215 & 15,124 & 28,125 & 32,685 & 38,361 & 38,231 & 41,303 & 44,644 \\
\hline Public sector & 4,461 & 4,806 & 9,721 & 11,922 & 13,456 & 12,939 & 11,407 & 11,317 \\
\hline Private sector & 11,753 & 10,317 & 18,404 & 20,763 & 24,905 & 25,292 & 29,896 & 33,327 \\
\hline Domestic saving & 6,591 & 9,230 & 1,090 & 956 & -498 & 2,407 & 3,798 & 4,023 \\
\hline Public sector & -436 & 204 & $-3,414$ & $-4,824$ & $-5,051$ & $-4,364$ & $-2,634$ & 339 \\
\hline Private sector & 7,027 & 9,026 & 4,504 & 5,780 & 4,554 & 6,771 & 6,432 & 3,684 \\
\hline National saving & 12,453 & 17,393 & 7,722 & 12,193 & 8,223 & 10,506 & 11,229 & 11,458 \\
\hline Public sector & 1,018 & 3,310 & $-2,408$ & $\ldots$ & $\ldots$ & $\ldots$ & ... & $\ldots$ \\
\hline Private sector & 11,435 & 14,083 & 10,131 & $\ldots$ & $\ldots$ & $\ldots$ & $\ldots$ & $\cdots$ \\
\hline
\end{tabular}


Table 3. Cape Verde: Sources and Uses of Ressources, 1991-98 (concluded)

\begin{tabular}{|c|c|c|c|c|c|c|c|c|}
\hline & 1991 & 1992 & 1993 & 1994 & 1995 & 1996 & 1997 & 1998 \\
\hline & \multicolumn{8}{|c|}{ (In percent of GDP) } \\
\hline Current account & -2.7 & -4.0 & -13.3 & -7.1 & -16.8 & -12.9 & -14.2 & -16.7 \\
\hline Ressource balance & $\ldots$ & $\ldots$ & -36.0 & -40.5 & -39.8 & -32.8 & -30.7 & -32.0 \\
\hline Exports of goods and NFS I/ & $\ldots$ & $\ldots$ & 13.3 & 14.8 & 19.1 & 22.7 & 27.2 & 24.9 \\
\hline Imports of goods and NFS $1 /$ & $\ldots$ & $\ldots$ & -49.3 & 55.3 & 58.9 & 55.5 & 57.9 & 56.9 \\
\hline Net factor income & 0.1 & 0.3 & -1.0 & -0.9 & -1.1 & -1.4 & -1.4 & -1.3 \\
\hline Public sector & -1.1 & -1.0 & -0.8 & $\ldots$ & $\ldots$ & $\ldots$ & $\ldots$ & $\ldots$ \\
\hline Private sector & 1.2 & 1.3 & -0.2 & $\ldots$ & $\ldots$ & $\ldots$ & $\ldots$ & $\ldots$ \\
\hline Unrequited transfers & 25.6 & 33.2 & 23.7 & 34.3 & 24.1 & 21.3 & 17.9 & 16.5 \\
\hline Public sector & 7.5 & 13.7 & 4.3 & 14.6 & 3.9 & 1.8 & 3.3 & -0.1 \\
\hline Private sector & 18.1 & 19.5 & 19.5 & 19.7 & 20.2 & 19.5 & 14.6 & 16.6 \\
\hline Gross national product & 100.1 & 100.3 & 99.0 & 99.1 & 98.9 & 98.6 & 98.6 & 98.7 \\
\hline Gross national income & 125.7 & 133.5 & 122.7 & 133.4 & 123.0 & 119.9 & 116.5 & 115.3 \\
\hline \multicolumn{9}{|l|}{ Public sector } \\
\hline Current revenue & 17.6 & 20.6 & 21.6 & 21.1 & 22.2 & 21.1 & 19.5 & 24.0 \\
\hline Current expenditure (treasury def.) & 19.6 & 19.7 & 19.8 & 19.6 & 21.3 & 19.2 & 19.3 & 18.1 \\
\hline Current expenditure (INE def.) & $\ldots$ & $\ldots$ & 33.3 & 35.4 & 35.5 & 31.8 & 25.3 & 23.3 \\
\hline Capital expenditure (treasury def.) & 13.8 & 28.9 & 28.2 & 32.0 & 27.0 & 25.5 & I8.9 & 17.1 \\
\hline Capital expenditure (INE def.) & $\ldots$ & $\ldots$ & 14.7 & 16.2 & 12.8 & 12.9 & 12.9 & 12.0 \\
\hline Grants & 10.9 & 19.3 & 15.3 & 15.2 & 14.8 & 13.3 & 10.5 & 10.8 \\
\hline Loans & 2.8 & 5.0 & 5.4 & 4.5 & 3.0 & 4.3 & 1.4 & 4.3 \\
\hline Domestic & 0.1 & 4.6 & 7.5 & 8.7 & 5.8 & 4.0 & 5.4 & 0.0 \\
\hline Of which : privatization & $\cdots$ & $\cdots$ & $\ldots$ & 0.2 & 4.2 & 5.7 & 3.6 & 0.0 \\
\hline Gross domestic investment & 28.9 & 37.9 & 39.7 & 43.4 & 38.5 & 38.8 & 39.1 & 40.2 \\
\hline Fixed capital formation & 29.2 & 37.8 & 39.7 & 43.4 & 38.5 & 38.8 & 39.1 & 40.2 \\
\hline Public sector & 13.8 & 28.9 & 14.7 & 16.2 & 12.8 & 12.9 & 12.9 & 12.0 \\
\hline Private sector & 15.4 & 9.0 & 25.0 & 27.2 & 25.7 & 25.9 & 26.3 & 28.3 \\
\hline Change in stocks & -0.3 & 0.1 & $\ldots$ & $\cdot \ldots$ & $\ldots$ & $\ldots$ & $\ldots$ & $\ldots$ \\
\hline Domestic consumption & 71.1 & 62.1 & 96.3 & 97.2 & 101.3 & 94.1 & 91.6 & 91.7 \\
\hline Public sector & 19.6 & 19.7 & 33.3 & 35.4 & 35.5 & 31.8 & 25.3 & 23.3 \\
\hline Private sector & 51.5 & 42.4 & 63.0 & 61.7 & 65.8 & 62.2 & 66.3 & 68.5 \\
\hline Domestic saving & 28.9 & 37.9 & 3.7 & 2.8 & -1.3 & 5.9 & 8.4 & 8.3 \\
\hline Public sector & -1.9 & 0.8 & -11.7 & -14.3 & -13.3 & -10.7 & -5.8 & 0.7 \\
\hline Private sector & 30.8 & 37.1 & 15.4 & 17.2 & 12.0 & 16.7 & 14.3 & 7.6 \\
\hline National saving & 54.6 & 71.4 & 26.4 & 36.2 & 21.7 & 25.9 & 24.9 & 23.5 \\
\hline Public sector & 4.5 & 13.6 & -8.2 & $\ldots$ & $\ldots$ & $\ldots$ & $\cdots$ & $\ldots$ \\
\hline Private sector & 50.1 & 57.8 & 34.7 & $\ldots$ & $\ldots$ & $\ldots$ & $\ldots$ & $\ldots$ \\
\hline
\end{tabular}

Sources: National Institute of Statistics (INE); and staff estimates.

1/ NFS stands for "nonfactor services." 
Table 4. Cape Verde: Gross Domestic Product at Current Prices, 1991-98

\begin{tabular}{|c|c|c|c|c|c|c|c|c|}
\hline & \multirow[t]{2}{*}{1991} & \multirow[t]{2}{*}{1992} & \multirow[t]{2}{*}{1993} & \multirow[t]{2}{*}{1994} & \multirow[t]{2}{*}{1995} & 1996 & 1997 & \multirow{2}{*}{$\begin{array}{c}1998 \\
\text { Est. }\end{array}$} \\
\hline & & & & & & \multicolumn{2}{|c|}{ Prov. } & \\
\hline & \multicolumn{8}{|c|}{ (In millions of Cape Verde escudos) } \\
\hline Agriculture, forestry, and livestock & 2,592 & 2,508 & 3,462 & 3,646 & 4,469 & 4,547 & 5,160 & 5,212 \\
\hline Fishing & 474 & 363 & 545 & 645 & 663 & 735 & 736 & 740 \\
\hline Industry and energy & 2,197 & 2,400 & 2,699 & 3,049 & 3.585 & 4,173 & 4,444 & 4,711 \\
\hline Construction & 2,688 & 2,925 & 3,165 & 3,476 & 3,566 & 3,825 & 3,938 & 4,304 \\
\hline Commerce & 3,923 & 4,070 & 4,446 & 5,429 & 6,074 & 6,363 & 6,975 & 7,571 \\
\hline Hotels & 318 & 319 & 423 & 455 & 456 & 625 & 1,464 & 1,669 \\
\hline Transport and communications & 3,766 & 4,333 & 5,162 & 6,292 & 6,363 & 6,839 & 7,589 & 8,575 \\
\hline Banks and insurance & 359 & 312 & 755 & 747 & 1,394 & 1,774 & 2,414 & 2,605 \\
\hline Housing & 1,745 & 1,907 & 1,939 & 2,087 & 2,431 & 2,527 & 2,896 & 3,099 \\
\hline Public service & 2,981 & 3,226 & 4,100 & 4,685 & 5,412 & 5,473 & 6,264 & 6,577 \\
\hline Other services & 1,763 & 1,991 & 2,405 & 2,991 & 3,280 & 3,569 & 2,960 & 3,315 \\
\hline \multirow[t]{3}{*}{ New industries } & 0 & 0 & 115 & 138 & 171 & 190 & 261 & 289 \\
\hline & 22,806 & 24,353 & 29,215 & 33,641 & 37,864 & 40,638 & 45,101 & 48,667 \\
\hline & \multicolumn{8}{|c|}{ (In percent of GDP) } \\
\hline Agriculture, forestry, and livestock & 11.4 & 10.3 & 11.8 & 10.8 & 11.8 & 11.2 & 11.4 & 10.7 \\
\hline Fishing & 2.1 & 1.5 & 1.9 & 1.9 & 1.8 & 1.8 & 1.6 & 1.5 \\
\hline Industry and energy & 9.6 & 9.9 & 9.2 & 9.1 & 9.5 & 10.3 & 9.9 & 9.7 \\
\hline Construction & 11.8 & 12.0 & 10.8 & 10.3 & 9.4 & 9.4 & 8.7 & 8.8 \\
\hline Commerce & 17.2 & 16.7 & 15.2 & 16.1 & 16.0 & 15.7 & 15.5 & 15.6 \\
\hline Hotels & 1.4 & 1.3 & 1.4 & 1.4 & 1.2 & 1.5 & 3.2 & 3.4 \\
\hline Transport and communications & 16.5 & 17.8 & 17.7 & 18.7 & 16.8 & 16.8 & 16.8 & 17.6 \\
\hline Banks and insurance & 1.6 & 1.3 & 2.6 & 2.2 & 3.7 & 4.4 & 5.4 & 5.4 \\
\hline Housing & 7.7 & 7.8 & 6.6 & 6.2 & 6.4 & 6.2 & 6.4 & 6.4 \\
\hline Public service & 13.1 & 13.2 & 14.0 & 13.9 & 14.3 & 13.5 & 13.9 & 13.5 \\
\hline Other services & 7.7 & 8.2 & 8.2 & 8.9 & 8.7 & 8.8 & 6.6 & 6.8 \\
\hline New industries & 0.0 & 0.0 & 0.4 & 0.4 & 0.5 & 0.5 & 0.6 & 0.6 \\
\hline \multirow[t]{2}{*}{ Gross domestic product } & 100.0 & 100.0 & 100.0 & 100.0 & 100.0 & 100.0 & 100.0 & 100.0 \\
\hline & \multicolumn{8}{|c|}{ (Annual percentage change) } \\
\hline Agriculture, forestry, and livestock & -6.6 & -3.2 & 38.0 & 5.3 & 22.6 & 1.7 & 13.5 & 1.0 \\
\hline Fishing & 47.1 & -23.4 & 50.1 & 18.4 & 2.8 & 10.8 & 0.2 & 0.5 \\
\hline Industry and energy & 7.9 & 9.3 & 12.4 & 13.0 & 17.6 & 16.4 & 6.5 & 6.0 \\
\hline Construction & 4.6 & 8.8 & 8.2 & 9.8 & 2.6 & 7.3 & 2.9 & 9.3 \\
\hline Commerce & -6.5 & 3.7 & 9.2 & 22.1 & 11.9 & 4.7 & 9.6 & 8.5 \\
\hline Hotels & -14.0 & 0.5 & 32.7 & .7 .4 & 0.3 & 37.0 & 134.3 & -14.0 \\
\hline Transport and communications & 15.3 & 15.1 & 19.1 & 21.9 & 1.1 & 7.5 & 11.0 & 13.0 \\
\hline Banks and insurance & 8.7 & -13.1 & 142.1 & -1.0 & 86.5 & 27.3 & 36.1 & 7.9 \\
\hline Housing & 5.0 & 9.3 & 1.7 & 7.6 & 16.5 & 4.0 & 14.6 & 7.0 \\
\hline Public service & 5.8 & 8.2 & 27.1 & 14.3 & 15.5 & 1.1 & 14.5 & 5.0 \\
\hline Other services & 45.1 & 12.9 & 20.8 & 24.4 & 9.6 & 8.8 & -17.1 & 12.0 \\
\hline New industries & $\cdots$ & $\ldots$ & $\ldots$ & 20.3 & 23.5 & 11.1 & 37.7 & 10.7 \\
\hline Gross domestic product & 5.8 & 6.8 & 20.0 & 15.2 & 12.6 & 7.3 & 11.0 & 7.9 \\
\hline
\end{tabular}

Sources: National Intitute of Statistics; and staff estimates. 
Table 5. Cape Verde: Gross Domestic Product at Constant 1980 Prices, 1991-98

\begin{tabular}{llllllllll}
\hline 1991 & 1992 & 1993 & 1994 & 1995 & $1996 \quad 1997$ & $\begin{array}{c}1998 \\
\text { Est. }\end{array}$
\end{tabular}

\begin{tabular}{|c|c|c|c|c|c|c|c|c|}
\hline \multirow[b]{2}{*}{ Agriculture, forestry, and livestock } & \multicolumn{8}{|c|}{ (In millions of Cape Verde escudos) } \\
\hline & 1,081 & 1,013 & 1,079 & 1,014 & 1,077 & $\cdots$ & $\cdots$ & $\ldots$ \\
\hline Fishing & 129 & 99 & 125 & 151 & 165 & $\ldots$ & $\ldots$ & $\ldots$ \\
\hline Industry and energy & 648 & 676 & 518 & 558 & 673 & $\ldots$ & $\ldots$ & $\ldots$ \\
\hline Construction & 1,341 & 1,389 & 1,458 & 1,486 & 1,541 & $\ldots$ & $\ldots$ & $\ldots$ \\
\hline Commerce & 2,094 & 2,062 & 2,113 & 2,258 & 2,460 & $\ldots$ & $\ldots$ & $\ldots$ \\
\hline Hotels & 119 & 123 & 160 & 169 & 152 & $\ldots$ & $\ldots$ & $\ldots$ \\
\hline Transport and communications & 1,348 & 1,512 & 1,890 & 2,185 & 2,241 & $\ldots$ & $\ldots$ & $\ldots$ \\
\hline Banks and insurance & 152 & 128 & 207 & 202 & 362 & $\ldots$ & $\ldots$ & $\ldots$ \\
\hline Housing & 739 & 781 & 821 & 852 & 898 & $\ldots$ & $\ldots$ & $\ldots$ \\
\hline Public service & 1,263 & 1,322 & 1,511 & 1,513 & 1,670 & $\ldots$ & $\ldots$ & $\ldots$ \\
\hline Other services & 750 & 873 & 801 & 1,034 & 1,039 & $\ldots$ & $\ldots$ & $\ldots$ \\
\hline Gross domestic product & 9,662 & 9,977 & \multicolumn{6}{|c|}{ (In percent of GDP) } \\
\hline Agriculture, forestry, and livestock & 11.2 & 10.2 & 10.1 & 8.9 & 8.8 & $\ldots$ & $\ldots$ & $\ldots$ \\
\hline Fishing & 1.3 & 1.0 & 1.2 & 1.3 & 1.3 & $\ldots$ & $\ldots$ & $\ldots$ \\
\hline Industry and energy & 6.7 & 6.8 & 4.8 & 4.9 & 5.5 & $\ldots$ & $\ldots$ & $\ldots$ \\
\hline Construction & 13.9 & 13.9 & 13.6 & 13.0 & 12.6 & $\ldots$ & $\ldots$ & $\ldots$ \\
\hline Commerce & 21.7 & 20.7 & 19.8 & 19.8 & 20.0 & $\ldots$ & $\ldots$ & $\ldots$ \\
\hline Hotels & 1.2 & 1.2 & 1.5 & 1.5 & 1.2 & $\ldots$ & $\ldots$ & $\ldots$ \\
\hline Transport and communications & 13.9 & 15.2 & 17.7 & 19.1 & 18.3 & $\ldots$ & $\ldots$ & $\ldots$ \\
\hline Banks and insurance & 1.6 & 1.3 & 1.9 & 1.8 & 3.0 & $\ldots$ & $\ldots$ & $\ldots$ \\
\hline Housing & 7.7 & 7.8 & 7.7 & 7.5 & 7.3 & $\ldots$ & $\ldots$ & $\ldots$ \\
\hline Public service & 13.1 & 13.2 & 14.1 & 13.2 & 13.6 & $\ldots$ & $\ldots$ & $\ldots$ \\
\hline Other services & 7.8 & 8.7 & 7.5 & 9.0 & 8.5 & $\ldots$ & $\ldots$ & $\ldots$ \\
\hline \multirow[t]{2}{*}{ Gross domestic product } & 100.0 & 100.0 & 100.0 & 100.0 & 100.0 & 100.0 & 100.0 & 100.0 \\
\hline & \multicolumn{8}{|c|}{ (Annual percentage change) } \\
\hline Agriculture, forestry, and livestock & -8.7 & -6.2 & 6.5 & -6.0 & 6.2 & $\ldots$ & $\ldots$ & $\ldots$ \\
\hline Fishing & 8.5 & -23.0 & 26.2 & 21.2 & 9.4 & $\ldots$ & $\ldots$ & $\ldots$ \\
\hline Industry and energy & 6.2 & 4.3 & -23.5 & 7.9 & 20.5 & $\ldots$ & $\ldots$ & $\ldots$ \\
\hline Construction & 1.4 & 3.6 & 4.9 & 1.9 & 3.7 & $\ldots$ & $\ldots$ & $\ldots$ \\
\hline Commerce & -5.9 & -1.5 & 2.5 & 6.9 & 8.9 & $\ldots$ & $\ldots$ & $\ldots$ \\
\hline Hotels & -13.0 & 3.7 & 30.4 & 5.4 & -10.1 & $\ldots$ & $\ldots$ & $\ldots$ \\
\hline Transport and communic & 15.6 & 12.2 & 25.0 & 15.6 & 2.6 & $\ldots$ & $\ldots$ & $\ldots$ \\
\hline Banks and insurance & 4.2 & -15.9 & 62.1 & -2.2 & 79.1 & $\ldots$ & $\ldots$ & $\ldots$ \\
\hline Housing & 0.7 & 5.7 & 5.1 & 3.7 & 5.4 & $\ldots$ & $\ldots$ & $\ldots$ \\
\hline Public service & 1.5 & 4.6 & 14.3 & 0.2 & 10.4 & $\ldots$ & $\ldots$ & $\ldots$ \\
\hline Other services & 17.1 & 16.3 & -8.2 & 29.0 & 0.5 & $\cdots$ & $\cdots$ & $\ldots$ \\
\hline Gross domestic product & 1.4 & 3.3 & 7.1 & 6.9 & 7.5 & 3.5 & 5.2 & 5.0 \\
\hline
\end{tabular}

Source: National Institute of Statistics; and staff estimates. 
Table 6. Cape Verde: Production in Agriculture, Livestock, and Fishing, 1991-98 (In metric tons)

\begin{tabular}{|c|c|c|c|c|c|c|c|c|}
\hline & 1991 & 1992 & 1993 & 1994 & 1995 & 1996 & 1997 & 1998 \\
\hline \multicolumn{9}{|l|}{ Agriculture } \\
\hline Bananas & 6,000 & 6,600 & 6,600 & 5,200 & $\ldots$ & $\ldots$ & $\ldots$ & $\ldots$ \\
\hline Potatoes & 2,660 & 2,750 & 2,672 & 1,800 & 2,160 & 2,090 & $\ldots$ & ... \\
\hline Sweet potatoes & 6,800 & 3,360 & 10,240 & 7,800 & 3,164 & 3,910 & $\ldots$ & $\ldots$ \\
\hline Coffee & 10 & $\ldots$ & 10 & 10 & $\ldots$ & $\ldots$ & $\ldots$ & $\ldots$ \\
\hline Sugarcane & 18,000 & 18,000 & 18,860 & $\ldots$ & $\ldots$ & $\ldots$ & $\ldots$ & $\ldots$ \\
\hline Beans & 2,217 & 3,182 & 1,796 & 1,500 & 3,200 & 3,060 & & $\ldots$ \\
\hline Manioc & 3,400 & 1,500 & 1,900 & $\ldots$ & $\ldots$ & $\ldots$ & $\ldots$ & $\ldots$ \\
\hline Maize & 8,258 & 10,265 & 11,888 & 3,163 & 8,166 & 1,304 & $\ldots$ & $\ldots$ \\
\hline Vegetables & 5,695 & 6,530 & 8,132 & 8,060 & 8,725 & 17,492 & $\ldots$ & $\ldots$ \\
\hline \multicolumn{9}{|l|}{ Livestock } \\
\hline Beef & 366 & 380 & 395 & $\ldots$ & 694 & $\ldots$ & $\ldots$ & $\ldots$ \\
\hline Chicken & 488 & 675 & 629 & $\ldots$ & 1,882 & $\ldots$ & $\ldots$ & $\ldots$ \\
\hline Goat & 398 & 346 & 689 & $\ldots$ & 445 & $\ldots$ & $\ldots$ & $\ldots$ \\
\hline Lamb & 21 & 23 & 25 & $\ldots$ & 64 & $\ldots$ & $\ldots$ & $\ldots$ \\
\hline Pork & 3,360 & 4,296 & 5,494 & $\ldots$ & 3,006 & $\ldots$ & $\ldots$ & $\ldots$ \\
\hline \multicolumn{9}{|l|}{ Fishing } \\
\hline Fish & 6,839 & 6,571 & 7,000 & 8,256 & 8,242 & 9,725 & $\ldots$ & ... \\
\hline Shellfish & 60 & 108 & 106 & $\ldots$ & $\ldots$ & $\ldots$ & $\ldots$ & $\ldots$ \\
\hline
\end{tabular}

Sources: National Commission for the Assessment of the Agricultural Year (INDP); and staff estimates 
Table 7. Cape Verde: Industrial Production, 1991-98

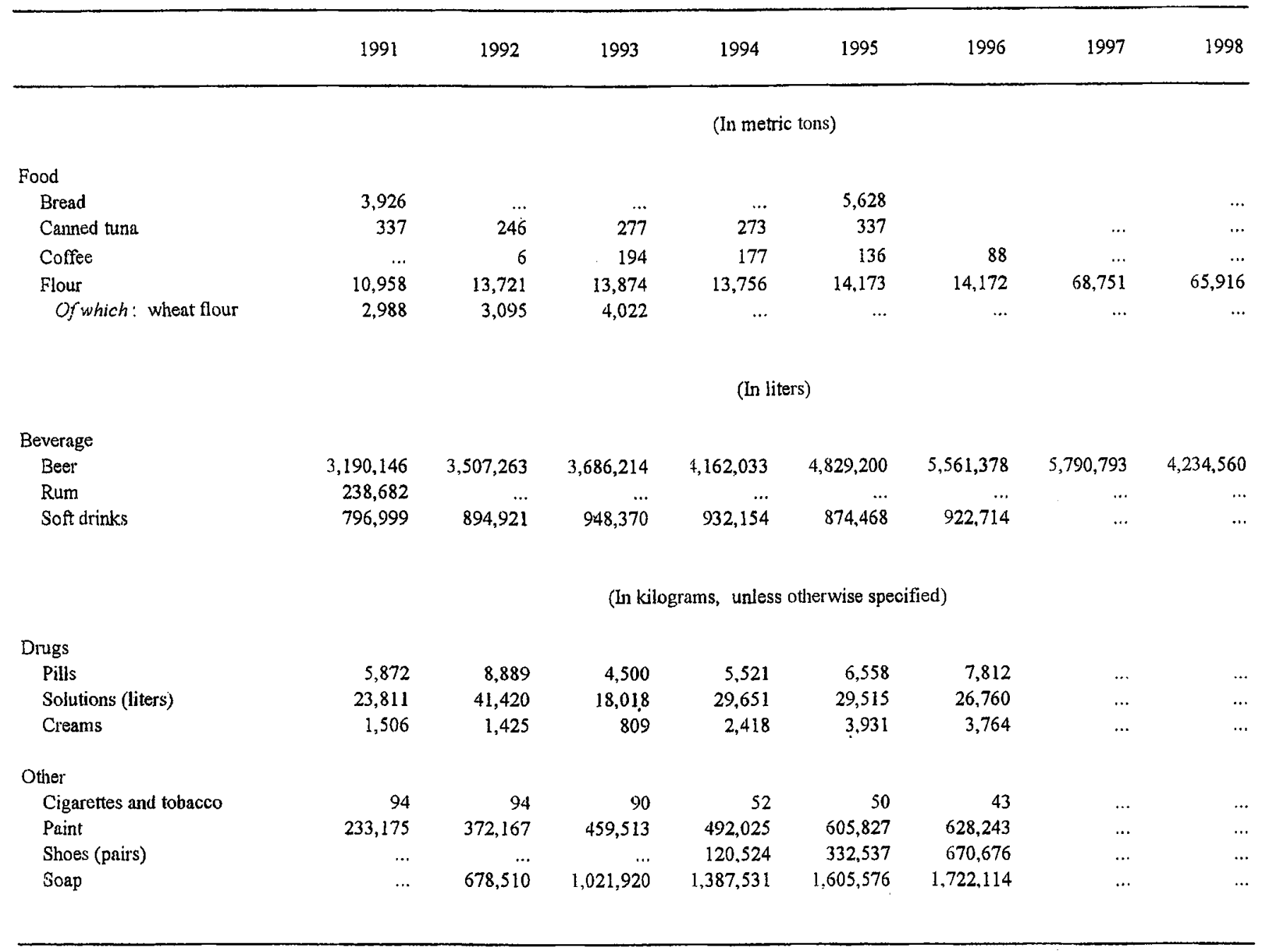

Sources: Boletim Trimestral de Estatistica; General Directorate of Statistics (DGE), Ministry of Economic Coordination, and General Directorate of Fishing (DGP) Ministry of Fisheries, Agriculture, and Rural Development; and staff estimates. 
Table 8. Cape Verde: Production and Consumption of Electricity and Water, 1991-98

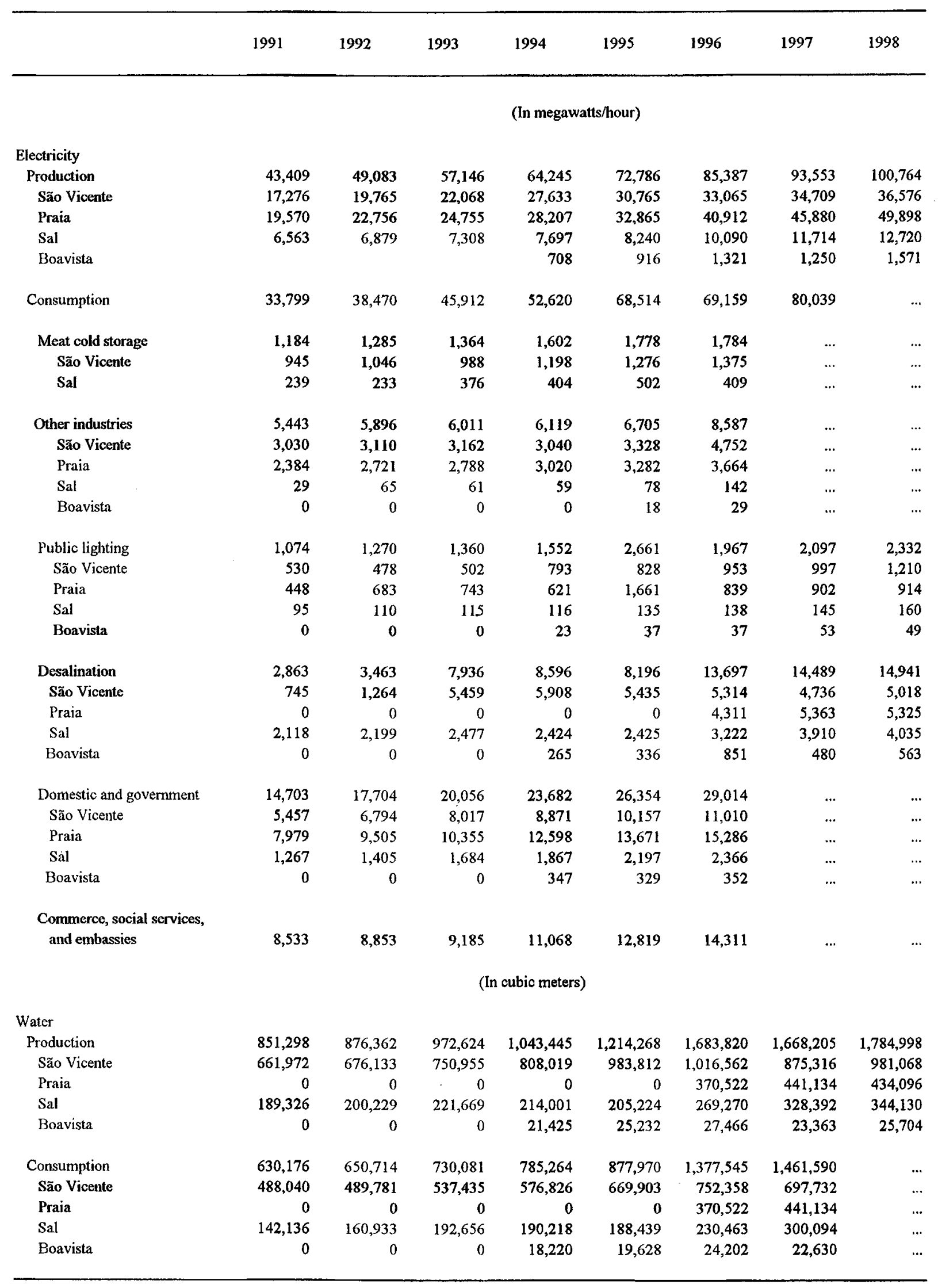

Sources: Electricity company (ELECTRA); and staff estimates. 
Table 9. Cape Verde: Consumption of Petroleum Products, 1991-98

(In metric tons)

\begin{tabular}{|c|c|c|c|c|c|c|c|c|}
\hline & 1991 & 1992 & 1993 & 1994 & 1995 & 1996 & 1997 & 1998 \\
\hline Domestic consumption & 40,417 & 43,749 & 65,383 & 68,145 & 70,329 & 79,741 & 96,136 & 98,392 \\
\hline Fuel & 8,527 & 7,859 & 11,323 & 8,379 & 11,213 & 9,063 & 12,066 & 17,888 \\
\hline Gas oil & 12,106 & 14,860 & 32,193 & 38,397 & 39,366 & 46,209 & 51,225 & 50,053 \\
\hline Jet fuel & 6,898 & 7,122 & 7,739 & 8,014 & 5,500 & 8,581 & 15,387 & 12,469 \\
\hline Kerosene & 2,129 & 2,028 & 1,804 & $\ldots$ & $\ldots$ & 1,418 & 1,642 & 1,610 \\
\hline Gasoline & 4,660 & 5,150 & 5,338 & 5,803 & 6,080 & 6,185 & 7,458 & 7,660 \\
\hline Butane & 6,097 & 6,730 & 6,986 & 7,552 & 8,170 & 8,285 & 8,358 & 8,712 \\
\hline Reexports & 49,997 & 56,038 & 43,028 & 66,525 & 75,452 & 70,036 & 103,347 & 90,209 \\
\hline Fuel & 401 & 189 & $\ldots$ & $\ldots$ & $\ldots$ & 1,182 & 3,387 & 1,961 \\
\hline Gas oil & 2,121 & 3,890 & 603 & 5,665 & 5,373 & 6,362 & 8,311 & 11,032 \\
\hline Jet fuel & 47,475 & 51,959 & 42,425 & 60,860 & 70,079 & 62,492 & 91,649 & 77,216 \\
\hline
\end{tabular}

Sources: Cape Verdean authorities; petroleum companies (ENACOL, Shell Oil Company of Cape Verde); and staff estimates. 
Table 10. Cape Verde: Public Investment Expenditure, 1991-98

(In millions of Cape Verde escudos)

\begin{tabular}{|c|c|c|c|c|c|c|c|c|}
\hline & 1991 & 1992 & 1993 & 1994 & 1995 & 1996 & 1997 & $\begin{array}{l}1998 \\
\text { Budget }\end{array}$ \\
\hline Total expenditure & 5,091 & 7,026 & 8,241 & 10,054 & 9,394 & 10,219 & 8,507 & 10,630 \\
\hline Primary sector & 1,710 & 2,202 & 2,423 & 2,238 & 2,256 & 2,531 & 1,473 & 2,861 \\
\hline Fisheries & 227 & 780 & 807 & 480 & 192 & 231 & 188 & 1,645 \\
\hline Rural & 1,483 & 1,422 & 1,616 & 1,758 & 2,064 & 2,300 & 1,285 & 1,216 \\
\hline Secondary sector & 1,030 & 1,382 & 1,440 & 1,506 & 1,560 & 2,070 & 864 & 1,061 \\
\hline Industry & 70 & 149 & 259 & 222 & 266 & 245 & 60 & 310 \\
\hline Construction & 320 & 178 & 524 & 864 & 1,022 & 1,300 & 594 & 620 \\
\hline Commerce & 57 & 143 & 113 & 32 & 14 & 150 & 25 & 41 \\
\hline Housing & 583 & 912 & 544 & 388 & 258 & 375 & 185 & 90 \\
\hline Tertiary sector & 2,351 & 3,442 & 4,378 & 6,310 & 5,578 & 5,618 & 6,170 & 6,708 \\
\hline Tourism & 83 & 15 & 49 & 48 & 29 & 45 & 164 & 80 \\
\hline Transport and communication & 613 & 1,404 & 1,344 & 2,403 & 903 & 1,874 & 1,688 & 1,732 \\
\hline Energy, water, and sewage & 424 & 278 & 771 & 949 & 1,753 & 1,519 & 718 & 1,176 \\
\hline Public administration & 523 & 553 & 929 & 1,278 & 1,464 & $\ldots$ & 1,000 & 1,165 \\
\hline Health & 263 & 200 & 277 & 237 & 293 & 350 & 249 & 651 \\
\hline Social promotion & $\ldots$ & $\ldots$ & $\ldots$ & 0 & 227 & 300 & 152 & 34 \\
\hline Education & 436 & 954 & 1,008 & 1,395 & 909 & 1,530 & 1,514 & 1,304 \\
\hline Poverty alleviation & 0 & 0 & 0 & 0 & 0 & 0 & 685 & 566 \\
\hline Other & 9 & 38 & 0 & 0 & 0 & 0 & 0 & 0 \\
\hline Financing & 5,091 & 7,026 & 8,241 & 10,054 & 9,394 & 10,219 & 8,507 & 10,630 \\
\hline Budgetary financing & 4,091 & 7,026 & $8,24 \mathrm{I}$ & 10,776 & 10,221 & 10,375 & 8,997 & 5,666 \\
\hline Foreign & 3,256 & 5,912 & 6,057 & 6,982 & 6,952 & 7,029 & 7,109 & 4,702 \\
\hline Grants & 2,861 & 4,694 & 4,473 & 5,120 & 5,602 & 5,139 & 4,975 & 3,499 \\
\hline Loans & 395 & 1,218 & 1,584 & 1,862 & 1,350 & 1,890 & 2,134 & 1,203 \\
\hline Domestic & 835 & 1,114 & 2,184 & 3,794 & 3,269 & 3,346 & 1,888 & 964 \\
\hline Nonbudgetary financing & 1,000 & .0 & 0 & -722 & -827 & -156 & -490 & 4,964 \\
\hline
\end{tabular}

Sources: General Directorate of Planning (DGP), Ministry of Economic Coordination; and staff estimates. 
Table 11. Cape Verde: Consumer Prices, 1991-98

\begin{tabular}{|c|c|c|c|c|c|c|c|c|}
\hline & 1991 & 1992 & 1993 & 1994 & 1995 & 1996 & 1997 & 1998 \\
\hline & \multicolumn{8}{|c|}{ (İnaex: $i \bar{y} \bar{u}=i \bar{u}$ ) } \\
\hline January & $\ldots$ & 119.4 & 124.2 & 131.0 & 140.8 & 144.6 & 159.6 & 169.5 \\
\hline February & 103.2 & 121.1 & 124.9 & 129.5 & 140.8 & 145.5 & 163.4 & 169.4 \\
\hline March & $\ldots$ & 120.5 & 125.7 & 129.5 & 141.3 & 147.7 & 164.2 & 167.8 \\
\hline April & & 122.0 & 126.3 & 131.4 & 140.8 & 149.4 & 165.7 & 168.9 \\
\hline May & 105.2 & 121.8 & 126.8 & 133.2 & 143.6 & 160.5 & 165.2 & 172.0 \\
\hline June & $\ldots$ & 121.5 & 129.3 & 133.8 & 143.0 & 152.2 & 167.1 & 171.5 \\
\hline July & $\ldots$ & 122.1 & 131.5 & 134.8 & 149.7 & 152.4 & 168.8 & 172.1 \\
\hline August & 111.4 & 121.5 & 135.4 & 136.5 & 150.7 & 157.7 & 170.8 & 175.8 \\
\hline September & $\ldots$ & 122.3 & 135.6 & 135.7 & 149.2 & 159.3 & 171.3 & 178.6 \\
\hline October & $\ldots$ & 123.6 & 129.5 & 135.6 & 147.1 & 157.1 & 166.5 & 179.1 \\
\hline November & 110.6 & 122.9 & 129.2 & 135.6 & 145.6 & 156.7 & 167.6 & 179.1 \\
\hline December & $\ldots$ & 126.0 & $131.5^{\circ}$ & 135.8 & 144.6 & 157.7 & 168.3 & 182.3 \\
\hline \multirow[t]{2}{*}{ Average } & 107.6 & 122.1 & 129.1 & 133.5 & 144.8 & 153.4 & 166.5 & 173.8 \\
\hline & \multicolumn{8}{|c|}{ (Monthly percentage changes) } \\
\hline January & $\ldots$ & $\ldots$ & -1.5 & -0.4 & 3.7 & 0.0 & 1.2 & 0.7 \\
\hline February & -0.2 & 2.9 & 0.6 & -1.2 & 0.0 & 0.6 & 2.4 & -0.1 \\
\hline March & & $\ldots$ & 0.6 & 0.0 & 0.4 & 1.5 & 0.5 & -0.9 \\
\hline April & $\ldots$ & 1.2 & 0.5 & 1.5 & -0.4 & 1.2 & 0.9 & 0.7 \\
\hline May & 0.6 & -0.2 & 0.4 & 1.4 & 2.0 & 7.4 & -0.3 & 1.8 \\
\hline June & $\ldots$ & -0.2 & 2.0 & 0.4 & -0.4 & -5.2 & 1.2 & -0.3 \\
\hline July & $\ldots$ & 0.5 & 1.6 & 0.8 & 4.7 & 0.1 & 1.0 & 0.3 \\
\hline August & 2.0 & -0.5 & 3.0 & 1.3 & 0.7 & 3.5 & 1.2 & 2.1 \\
\hline September & $\ldots$ & 0.6 & 0.1 & -0.6 & $-1: 0$ & 1.0 & 0.3 & 1.6 \\
\hline October & $\ldots$ & 1.1 & -4.5 & -0.1 & -1.4 & -1.4 & -2.8 & 0.3 \\
\hline November & -0.2 & -0.6 & -0.2 & 0.0 & -1.0 & -0.3 & 0.7 & 0.0 \\
\hline December & $\ldots$ & 2.5 & 1.8 & 0.1 & -0.7 & 0.6 & 0.4 & 1.8 \\
\hline \multirow[t]{2}{*}{ Average } & 0.5 & 1.1 & 0.4 & 0.3 & 0.5 & 0.8 & 0.6 & 0.7 \\
\hline & \multicolumn{8}{|c|}{ (Annual percentage changes) } \\
\hline January & $\ldots$ & & 4.0 & 5.5 & 7.5 & 2.7 & 10.4 & 6.2 \\
\hline February & 2.5 & 16.6 & 3.1 & 3.7 & 8.8 & 3.3 & 12.3 & 3.7 \\
\hline March & $\ldots$ & $\ldots$ & 4.3 & 3.1 & 9.1 & 4.5 & 11.2 & 2.2 \\
\hline April & $\ldots$ & $\ldots$ & 3.6 & 4.0 & 7.1 & 6.1 & 10.9 & 1.9 \\
\hline May & 2.5 & 15.8 & 4.1 & 5.1 & 7.8 & 11.8 & 2.9 & 4.1 \\
\hline June & $\ldots$ & $\ldots$ & 6.5 & 3.4 & 6.9 & 6.4 & 9.8 & 2.6 \\
\hline July & $\ldots$ & $\ldots$ & 7.7 & 2.5 & 11.1 & 1.8 & 10.8 & 2.0 \\
\hline August & 3.0 & 9.5 & 11.5 & 0.8 & 10.4 & 4.6 & 8.3 & 2.9 \\
\hline September & $\ldots$ & $\ldots$ & 10.9 & 0.1 & 9.9 & 6.8 & 7.5 & 4.3 \\
\hline October & $\ldots$ & $\ldots$ & 4.7 & 4.7 & 8.5 & 6.8 & 6.0 & 7.6 \\
\hline November & 2.2 & 12.3 & 5.1 & 5.0 & 7.4 & 7.6 & 7.0 & 6.9 \\
\hline December & $\ldots$ & $\ldots$ & 4.4 & 3.3 & 6.5 & 9.1 & 6.7 & 8.3 \\
\hline Average & 2.5 & 13.5 & 5.8 & 3.4 & 8.4 & 6.0 & 8.6 & 4.3 \\
\hline
\end{tabular}

Sources: National Institute of Statistics (INE); and staff estimates. 
Table 12. Cape Verde: Average Daily Salary by Occupation, 1991-98

(In Cape Verde escudos)

\begin{tabular}{|c|c|c|c|c|c|c|c|c|}
\hline & 1991 & 1992 & 1993 & 1994 & 1995 & 1996 & 1997 & 1998 \\
\hline Baker & 540 & 830 & 350 & 350 & 366 & 500 & 510 & 510 \\
\hline Bricklayer & 413 & 650 & 509 & 509 & 475 & 733 & 1,000 & 1,333 \\
\hline Car driver & 540 & 622 & 690 & 690 & 666 & 666 & 766 & 800 \\
\hline Carpenter & 501 & 650 & 639 & 639 & 666 & 666 & 701 & 721 \\
\hline Carpenter's assistant & 215 & 240 & 288 & 345 & 350 & 400 & 450 & 470 \\
\hline Cashier (commerce) & 850 & 955 & 955 & 955 & 833 & 900 & 1,235 & 1,266 \\
\hline Clerk & 1,100 & 1,283 & $\ldots$ & $\ldots$ & 1,200 & 883 & 910 & 910 \\
\hline Digger & 270 & 316 & 316 & 316 & 350 & 400 & 470 & 502 \\
\hline Foreman & $\ldots$ & $\ldots$ & $\ldots$ & $\ldots$ & 460 & $\ldots$ & 1,440 & 1,440 \\
\hline Forgeman & 378 & 490 & 490 & 490 & 800 & 1,000 & 1,100 & 1,150 \\
\hline Kneader & 210 & 210 & 252 & 330 & 350 & 482 & 500 & 530 \\
\hline Locksmith & 520 & 543 & 543 & 578 & 950 & 700 & 750 & 802 \\
\hline Master carpenter & 444 & 510 & $\ldots$ & $\ldots$ & 750 & 800 & 1,150 & 1,500 \\
\hline Master mason & 610 & 1,033 & $\ldots$ & $\ldots$ & 800 & 1,166 & 1,440 & 1,440 \\
\hline Mechanic & 707 & 838 & 838 & 848 & 950 & 800 & 906 & 1,066 \\
\hline Painter & 385 & 713 & 750 & 801 & 600 & 666 & 800 & 916 \\
\hline Paver & 195 & 276 & 298 & 331 & 366 & 400 & 503 & 607 \\
\hline Porter & $\ldots$ & $\ldots$ & 247 & 276 & $\ldots$ & 400 & 502 & 530 \\
\hline Sales clerk (commerce) & 553 & 630 & 630 & 630 & 667 & 700 & 730 & 745 \\
\hline Servant & 150 & 150 & 200 & 233 & 700 & 500 & 520 & 550 \\
\hline Store assistant (commerce) & 406 & 559 & $\ldots$ & $\ldots$ & 833 & 840 & 847 & 850 \\
\hline Store head (commerce) & 866 & 960 & 960 & 960 & 1,000 & 1,833 & 1,900 & 1,980 \\
\hline Worker & 387 & 387 & $\ldots$ & $\ldots$ & 450 & 500 & 500 & 530 \\
\hline
\end{tabular}

Sources: General Directorate of Labor and Employment (DGTE), Ministry of Justice and Labor; and staff estimates. 
Table 13. Cape Verde: Basic Monthly Civil Service Salaries by Grade, 1991-98

(In Cape Verde escudos)

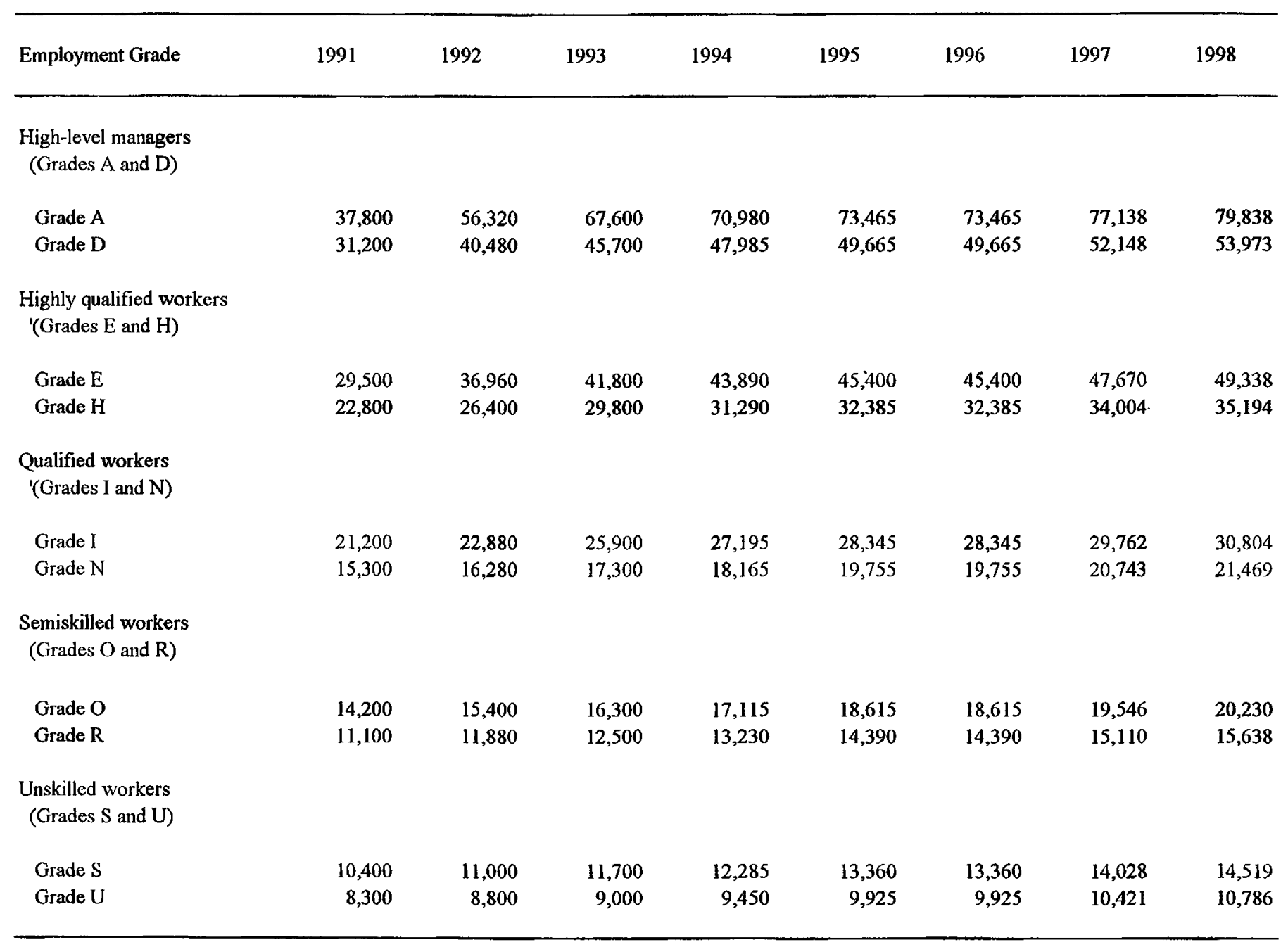

Source: Cape Verdean authorities. 
Table 14. Cape Verde: Civil Service Employment by Administrative Unit, 1992-98

\begin{tabular}{|c|c|c|c|c|c|c|c|}
\hline & 1992 & 1993 & 1994 & 1995 & 1996 & 1997 & 1998 \\
\hline Permanent staff & 3,025 & $\ldots$ & 4,167 & 3,980 & $\ldots$ & ... & ... \\
\hline National Assembly & 8 & $\ldots$ & 0 & 0 & $\ldots$ & $\ldots$ & $\ldots$ \\
\hline Presidency & 8 & $\ldots$ & 0 & 0 & $\ldots$ & $\ldots$ & $\ldots$ \\
\hline Office of the Prime Minister & 93 & $\ldots$ & 27 & 28 & $\ldots$ & $\ldots$ & $\ldots$ \\
\hline Ministries & 1,323 & $\ldots$ & 2,070 & 1,976 & $\ldots$ & $\ldots$ & $\ldots$ \\
\hline Presidency of the Ministry Council & 0 & $\ldots$ & 0 & 0 & ... & $\ldots$ & $\ldots$ \\
\hline Assistant to the Prime Minister & 0 & $\ldots$ & 0 & 0 & $\ldots$ & $\ldots$ & $\ldots$ \\
\hline Agriculture and Rural Development & 101 & $\ldots$ & 0 & 0 & $\ldots$ & $\ldots$ & $\ldots$ \\
\hline Defense & 7 & $\ldots$ & 1,454 & 1,454 & ... & $\ldots$ & $\ldots$ \\
\hline Economic Coordination/Finance & 231 & $\ldots$ & 0 & 0 & $\ldots$ & $\ldots$ & $\ldots$ \\
\hline Education & 371 & $\ldots$ & 0 & 0 & $\ldots$ & $\ldots$ & $\ldots$ \\
\hline Foreign Affairs & 43 & $\ldots$ & 0 & 0 & $\ldots$ & $\ldots$ & $\ldots$ \\
\hline Health & 248 & $\ldots$ & 264 & 264 & $\ldots$ & $\ldots$ & $\ldots$ \\
\hline Infrastructure and Transportation & 167 & $\ldots$ & 352 & 258 & $\ldots$ & $\ldots$ & ... \\
\hline Justice and Labor & 69 & $\ldots$ & 0 & 0 & $\ldots$ & $\ldots$ & $\ldots$ \\
\hline Sea $1 /$ & 0 & $\ldots$ & 0 & 0 & $\ldots$ & $\ldots$ & $\ldots$ \\
\hline Other & 86 & $\ldots$ & 0 & 0 & $\ldots$ & $\cdots$ & $\ldots$ \\
\hline Other & 270 & $\ldots$ & 0 & 0 & $\ldots$ & $\ldots$ & $\ldots$ \\
\hline Total staff & 19,579 & $\ldots$ & 17,139 & 21,037 & ... & $\ldots$ & 23,875 \\
\hline National Assembly & 78 & $\ldots$ & 0 & 81 & $\ldots$ & $\ldots$ & 120 \\
\hline Presidency & 55 & $\ldots$ & 0 & 60 & $\ldots$ & $\ldots$ & 60 \\
\hline Office of the Prime Minister & 347 & $\ldots$ & 42 & 60 & $\ldots$ & $\ldots$ & 41 \\
\hline Ministries & 8,379 & $\ldots$ & 5,375 & 9,153 & $\ldots$ & $\ldots$ & 11,827 \\
\hline Presidency of the Ministry Council & 0 & $\ldots$ & 0 & 179 & $\ldots$ & $\ldots$ & 39 \\
\hline Assistant to the Prime Minister & 0 & $\ldots$ & 0 & 0 & $\ldots$ & $\ldots$ & 122 \\
\hline Agriculture and Rural Development & 755 & $\ldots$ & 0 & 772 & $\ldots$ & $\ldots$ & 393 \\
\hline Defense & 121 & $\ldots$ & 0 & 153 & $\ldots$ & $\ldots$ & 37 \\
\hline Economic Coordination/Finance & 566 & $\ldots$ & 0 & 637 & $\ldots$ & $\ldots$ & 2,697 \\
\hline Education & 4,254 & $\ldots$ & 4,790 & 4,759 & $\ldots$ & $\ldots$ & 6,272 \\
\hline Foreign Affairs & 213 & $\ldots$ & 186 & 215 & $\ldots$ & $\ldots$ & 179 \\
\hline Health & 1,264 & ;. & 0 & 1,335 & $\ldots$ & $\ldots$ & 1,287 \\
\hline Infrastructure and Transportation & 522 & $\ldots$ & 399 & 620 & $\ldots$ & $\ldots$ & 190 \\
\hline Justice and Labor & 326 & $\ldots$ & 0 & 483 & $\ldots$ & $\ldots$ & 552 \\
\hline Sea $1 /$ & 0 & $\ldots$ & 0 & 0 & $\ldots$ & $\ldots$ & 59 \\
\hline Other & 358 & $\ldots$ & 0 & 0 & $\ldots$ & $\cdots$ & 0 \\
\hline Other & 2,341 & $\ldots$ & 6,347 & 2,530 & $\ldots$ & $\ldots$ & 0 \\
\hline
\end{tabular}

Sources: General Directorate of Public Administration, Ministry of Civil Service and Parliamentary Affairs; Ministry of Finance; and staff estimates.

1/ Until 1993, rural development was part of the Ministry of Sea. 
Table 15. Cape Verde: Fiscal Operations of the Central Govemment, 1994-98

\begin{tabular}{|c|c|c|c|c|c|c|c|c|c|c|}
\hline & \multirow[t]{3}{*}{1994} & \multirow[t]{3}{*}{1995} & \multirow[t]{3}{*}{1996} & \multirow[t]{3}{*}{1997} & \multicolumn{6}{|c|}{1998} \\
\hline & & & & & \multicolumn{2}{|c|}{ Jun. } & \multicolumn{2}{|c|}{ Sep. } & \multicolumn{2}{|c|}{ Dec. } \\
\hline & & & & & Prog. & Est. & Rev. Prog. & Est. & Rev. Prog. & Est. \\
\hline & \multicolumn{10}{|c|}{ (In miltions of Cape Verde escudos) } \\
\hline Total revenue, grants, and capital participation & 12,992 & 14,630 & 13,986 & 14,328 & 7,677 & 7,356 & 12,155 & 11,628 & 17,652 & 16,961 \\
\hline Total revenue & 7,098 & 8,405 & 8,575 & 8,773 & 4,955 & 5,256 & 7,835 & 7,797 & 11.528 & 11.656 \\
\hline Tnx revenue $\mathrm{V} /$ & 5,590 & 6,408 & 6,961 & 7,479 & $\mathbf{3 , 7 8 0}$ & 3.973 & 5,850 & 5,933 & 8,081 & 8.409 \\
\hline Nontax revenue $2 /$ & 1,509 & 1.997 & 1,615 & 1,294 & 1,174 & 1,283 & 1,985 & 1,864 & 3,447 & 3,247 \\
\hline Extemal grants & 5,120 & 5.602 & 5,411 & 4,750 & $\mathbf{2 , 6 7 4}$ & 2,100 & 4,248 & 3,767 & 6,028 & 5,241 \\
\hline Domestic capital participation 3 / & 774 & 623 & 0 & 805 & 48 & 0 & 72 & 64 & 96 & 64 \\
\hline Total expenditure & 17,699 & 19,508 & 19,647 & 19,036 & 10,461 & 9,273 & 15,764 & 14,556 & 21,215 & 19,037 \\
\hline Recurrent expenditure $2 /$ & 6,923 & 9,287 & 9,272 & 10.529 & 5,371 & 5,613 & 8,239 & 7,686 & 10,886 & 10,718 \\
\hline Primary current expenditure & 6,582 & 8,079 & 7.779 & $\mathbf{8 , 6 9 7}$ & 4,760 & $\ldots$ & 7,246 & 6,635 & 9,100 & $\mathbf{8 , 8 2 5}$ \\
\hline Wage bill & 3,396 & 3,949 & 4,284 & 4,529 & 2,373 & $\ldots$ & 3.659 & 3.875 & 4.745 & 4,894 \\
\hline Goods and services & 281 & 285 & 284 & 619 & ... & $\ldots$ & 410 & 303 & 417 & 350 \\
\hline Transfers and subsidies & 1,169 & 1,667 & 1,535 & 2,893 & $\ldots$ & $\ldots$ & 2,534 & 1,810 & 2,672 & 2,672 \\
\hline Other current expenditure & 1,736 & 2,178 & 1,676 & 656 & $\ldots$ & $\ldots$ & 643 & 646 & 1,266 & 910 \\
\hline Domestic interest accrual $4 /$ & .68 & 938 & 1,233 & 1,402 & 427 & 593 & 730 & 855 & 1,392 & 1,543 \\
\hline Of which: Trust Fund interest residual 4/ & $\ldots$ & $\ldots$ & ... & $\ldots$ & 427 & ... & 721 & 0 & 1,383 & \\
\hline Extemal interest accnual & 273 & 270 & 260 & .430 & 184 & 121 & 263 & 197 & 394 & 350 \\
\hline Extraordinary social expenditure & & $\ldots$ & $\ldots$ & $\ldots$ & $\ldots$ & $\ldots$. & $\ldots$ & $\ldots$ & $\ldots$ & ... \\
\hline Capital expenditure & 10,776 & 10,221 & 10,375 & 8,507 & 5,091 & 3,660 & 7,525 & 6,870 & 10,329 & 8,319 \\
\hline Foreign financed & 6,982 & 6,952 & 7,301 & 6,594 & 4,479 & $\ldots$ & $.6,716$ & 5.772 & 9,520 & 7,355 \\
\hline Domeslically financed & 3,794 & 3,269 & 3,074 & 1,913 & 612 & $\ldots$ & 809 & 1,098 & 809 & 964 \\
\hline Current balance & 175 & -883 & .697 & $-1,756$ & -416 & -357 & -404 & 111 & $64 !$ & 938 \\
\hline Primary balance & $-9,486$ & $-9,273$ & $-9,579$ & $-7,626$ & $-4,847$ & $-3,303$ & $-6,864$ & $-5,644$ & $-7,806$ & $-5,425$ \\
\hline Overall balance (commitment basis), incl. grants & $-4,707$ & $-4,879$ & $-5,661$ & $-4,708$ & $-2,784$ & $-1,917$ & $-3,609$ & $-2,928$ & $-3,564$ & $-2,077$ \\
\hline Overall balance (commitment basis), excl. grants & $-9,827$ & $-10,481$ & $-11,072$ & $-9,458$ & $-5,458$ & $-4,017$ & $-7,857$ & $-6,695$ & $-9,592$ & $-7,318$ \\
\hline Financing & 4,707 & 4,878 & 5,670 & 4,707 & 2,784 & 1.916 & 3,609 & 2,927 & 3,564 & 2,086 \\
\hline Foreign (net) & 1,654 & 1,117 & 1,742 & 649 & 1,786 & 434 & 2,568 & 2,051 & 3,564 & 2,086 \\
\hline Drawings $4 /$ & 1862 & 1350 & 1,890 & 1,844 & 2,232 & 750 & 3,075 & 2,582 & 4,568 & 2,967 \\
\hline Of which : bridge toan & & & & ... & 1,020 & $\ldots$ & 867 & 562 & 867 & 853 \\
\hline Amortizalion & -614 & -580 & .523 & -882 & .746 & .362 & $-1,003$ & -577 & $-1,601$ & -965 \\
\hline Change in arrears & 406 & 347 & 375 & $-1,777$ & o & 46 & 46 & 46 & -3 & 65 \\
\hline Interest & 72 & 68 & 95 & -546 & 0 & 41 & 41 & 41 & 0 & 0 \\
\hline Principal & 334 & 279 & 280 & $-1,231$ & 0 & 5 & 5 & 5 & -3 & 65 \\
\hline Of which: repayments of previous arrears & -159 & -21 & 0 & -186 & $\mathbf{0}$ & -3 & -3 & -3 & -3 & -3 \\
\hline Refinancing and reschoduling of arrears 5/ & 0 & 0 & 0 & 1.464 & 300 & 0 & 450 & 0 & 600 & 19 \\
\hline Cancellation & $\ldots$ & $\ldots$ & $\ldots$ & $\ldots$ & $\ldots$ & 0 & $\ldots$ & 0 & 0 & 0 \\
\hline Rescheduling & $\ldots$ & $\ldots$ & $\ldots$ & $\ldots$ & $\ldots$ & 0 & $\ldots$ & 0 & 600 & 19 \\
\hline Domestic (net) & 3053 & 3761 & 3.928 & 4,058 & 998 & 1,482 & 1,041 & 876 & 0 & 0 \\
\hline Banking system 6 / & 2133 & 1975 & 971 & 2.173 & 998 & $1, \mathbf{4 8 2}$ & 1.041 & 876 & $\mathbf{0}$ & 0 \\
\hline New loans (net) $7 /$ & 2133 & 1975 & 971 & 2.173 & 998 & 1.124 & $1,04 i$ & 876 & $\mathbf{0}$ & 0 \\
\hline Of which : bonds sold to banks & 1000 & 665 & 0 & 0 & $\mathbf{0}$ & $\ldots$ & e & $\mathbf{0}$ & $\mathbf{0}$ & $\ldots$ \\
\hline Change in arrears & 0 & 0 & 0 & $\mathbf{0}$ & $\mathbf{0}$ & 358 & 0 & o & $\mathbf{0}$ & 0 \\
\hline Other (net) & 920 & 1786 & 2,957 & 1.885 & 0 & 0 & 0 & 0 & 0 & 0 \\
\hline Of which: bonds sold to nonbanks & 900 & 578 & 0 & o & 0 & $\ldots$ & 0 & $\theta$ & 0 & 0 \\
\hline Privatizalion revenues & 69 & 1575 & 2,316 & 1,885 & $\mathbf{0}$ & $\ldots$ & 0 & o & 0 & $\ldots$ \\
\hline Financing gap & 0 & 1 & -9 & 1 & $\mathbf{0}$ & 1 & 0 & 1 & 0 & .9 \\
\hline & & & & & In percen & GDP) & & & & \\
\hline Total revenue, grants, and capital participation & 38.6 & 38.6 & 34.4 & 31.8 & $\ldots$ & $\ldots$ & ... & $\ldots$ & 36.3 & 34.9 \\
\hline Total revenue & 21.1 & 22.2 & 21.1 & 19.5 & $\ldots$ & $\ldots$ & $\ldots$ & $\ldots$ & 23.7 & 24.0 \\
\hline Tax revenue & 16.6 & 16.9 & 17.1 & 16.6 & $\cdots$ & $\ldots$ & $\ldots$ & $\ldots$ & 16.6 & 17.3 \\
\hline Nontax revenue & 4.5 & 5.3 & 4.0 & 2.9 & $\ldots$ & $\ldots$ & $\ldots$ & $\ldots$ & 7.1 & 6.7 \\
\hline External grants & 15.2 & 14.8 & 13.3 & 10.5 & $\ldots$ & $\ldots$ & $\ldots$ & $\ldots$ & 12.4 & 10.8 \\
\hline Domestic coqpital participation & 2.3 & 1.6 & 0.0 & 1.8 & $\ldots$ & ... & $\ldots$ & $\ldots$ & 0.2 & 0.1 \\
\hline Total expenditure & 52.6 & 51.5 & 48.3 & 42.2 & $\ldots$ & $\cdots$ & $\cdots$ & $\ldots$ & 43.6 & 39.1 \\
\hline Recurrent expenditure & 20.6 & 24.5 & 22.8 & 23.3 & $\ldots$ & $\cdots$ & $\ldots$ & $\ldots$ & 22.4 & 22.0 \\
\hline Recurrent primary expenditure & 19.6 & $21: 3$ & 19.1 & 19.3 & $\ldots$ & $\ldots$ & $\ldots$ & $\ldots$ & 18.7 & 18.1 \\
\hline Of which: wage bill & 10.1 & 10.4 & 10.5 & 10.0 & $\ldots$ & $\ldots$ & ... & $\ldots$ & 9.7 & 10.1 \\
\hline Capital expenditure & 32.0 & 27.0 & 25.5 & 18.9 & $\ldots$ & ... & ... & $\ldots$ & 21.2 & 17.1 \\
\hline Current balance & 0.5 & -2.3 & -1.7 & -3.9 & $\ldots$ & ... & $\ldots$ & $\ldots$ & 1.3 & 1.9 \\
\hline Primary balance & -28.2 & -24.5 & -23.6 & -16.9 & $\ldots$ & $\ldots$ & $\ldots$ & $\ldots$ & .16 .0 & $-11.1+$ \\
\hline Overall balance (commitment basis), incl. grants & -14.0 & -12.9 & -13.9 & -10.4 & $\ldots$ & ... & $\ldots$ & $\ldots$ & -7.3 & -4.3 \\
\hline Overall balance (commitment basis), excl. grants & -29.2 & -27.7 & -27.2 & .21 .0 & $\ldots$ & $\ldots$ & $\ldots$ & $\ldots$ & -19.7 & -15.0 \\
\hline Forcign financing (net) & 4.9 & 3.0 & 4.3 & 1.4 & $\ldots$ & $\cdots$ & $\ldots$ & $\ldots$ & 7.3 & 4.3 \\
\hline Domestic financing (net) & 9.1 & 9.9 & 9.7 & 9.0 & $\cdots$ & $\cdots$ & $\cdots$ & $\ldots$ & 0.0 & 0.0 \\
\hline Barking system financing & 6.3 & 5.2 & 2.4 & 4.8 & $\ldots$ & $\ldots$ & $\ldots$ & $\ldots$ & 0.0 & 0.0 \\
\hline Firlancing gap & 0.0 & 0.0 & 0.0 & 0.0 & $\ldots$ & $\ldots$ & $\ldots$ & $\ldots$ & 0.0 & 0.0 \\
\hline
\end{tabular}

Sources: Ministry of Finance; Bark of Cape Verde; and staff estimates.

1/ Since 1998, tax revenue excludes taxes collected on bchalf of the municipalities and the TPC (Economic Community of West African Stales).

2 Includes the so-called contas $d z$ ordem, which are budgeted revenues from direct provision of services by government agencies offset by the same amounts under current expenditure for each of these spencies.

3/ These are enterprises' shares of government investment costs, usually in infrastructure directly relaled to the activily of these enterprises.

4/ For 1998, include the drawings expected from the concessional line of credit to cover domestic interest payments.

5/ In 1999, Cape Verde is in the process of rescheduling its US\$6.49-million arrears with Spain and its USs7.29-million obligations with Bravil. While negotialions with Spain are still ongoing.

Brazil cancelled 60 percent and arsanged a ten-year repayment schedule with the Cape Verdean authonities.

6 / Net credit to govemment adjusted for public enterprise debt (CVEsc 3.1 and 0.3 billion, respectively in 1994 and 1995); and reclassification of expenditure executed in 1996 on account of 1995 (CVEsc 0.6 billion).

7/ Net of current amortization. 
Table 16. Cape Verde: Central Government Revenue, 1994-98

(In millions of Cape Verde escudos; unless otherwise indicated)

\begin{tabular}{|c|c|c|c|c|c|}
\hline & 1994 & 1995 & 1996 & 1997 & 1998 \\
\hline Tax revenue & 5,590 & 6,408 & 6,961 & 7,479 & 8,409 \\
\hline Taxes on income and profits & 1,978 & 2,201 & 2,521 & 2,844 & 3,068 \\
\hline Tax on business profits & 1,015 & 1,080 & 0 & 0 & 0 \\
\hline Unified tax & 0 & 0 & 2,314 & 2,571 & 2,836 \\
\hline Tax on salaries and self-employment income & 518 & 609 & 0 & 0 & 0 \\
\hline Tax on rentals & 68 & 70 & 80 & 91 & 33 \\
\hline Complementary tax & 289 & 347 & 0 & 0 & 0 \\
\hline Tax on the fuel distributors' profits and capital distril & 0 & 0 & 0 & 0 & 0 \\
\hline Tax on petroleum products $1 /$ & 88 & 96 & 127 & 182 & 161 \\
\hline Other taxes & 0 & 0 & 0 & 0 & 38 \\
\hline Of which: $m$ unicipal and TPC taxes & 0 & 0 & 0 & 0 & 0 \\
\hline Municipal taxes $2 /$ & 59 & 33 & 49 & 62 & 68 \\
\hline Estate and gift tax $2 /$ & 5 & 6 & 6 & 8 & 6 \\
\hline Tax on real estate transfers $2 /$ & 37 & 10 & 22 & 33 & 41 \\
\hline Motor-vehicle tax $2 /$ & 17 & 18 & 21 & 21 & 21 \\
\hline Taxes on international trade & 3,187 & 3,758 & 3,922 & 4,148 & 4,906 \\
\hline Taxes on imports & 3,175 & 3,714 & 3,869 & 4,085 & 4,866 \\
\hline Import duties & 1,377 & 1.717 & 1,787 & 1,874 & 2,306 \\
\hline Consumption taxes $3 /$ & 1,026 & 1,057 & 1,176 & 1,242 & 1,415 \\
\hline Customs services tax. & 772 & 940 & 906 & 969 & 1,145 \\
\hline Other & 12 & 44 & 53 & 63 & 40 \\
\hline Other taxes & 366 & 416 & 468 & 425 & 435 \\
\hline Stamp tax & 303 & 332 & 375 & 394 & 345 \\
\hline Liquor tax & 63 & 84 & 93 & 31 & 90 \\
\hline Nontax revenue & 1,509 & 1,997 & 1,615 & 1,294 & 3,247 \\
\hline Licenses and miscellaneous fees & 177 & 256 & 213 & 268 & 382 \\
\hline Property income & 208 & 487 & 594 & 367 & 428 \\
\hline Transfers & 420 & 425 & 543 & 257 & 256 \\
\hline Reimbursement of principal by public enterprises $3 /$ & 0 & 101 & 0 & 0 & 1,292 \\
\hline Sales of fixed assets and services & 215 & 190 & 264 & $2 \dot{88}$ & 264 \\
\hline Autonomous revenues $5 /$ & 489 & 530 & 0 & 0 & 495 \\
\hline Other revenues & 0 & 8 & 0 & 114 & 130 \\
\hline Total budgetary revenue & 7,098 & 8,405 & 8,575 & 8,773 & 11,656 \\
\hline Annual percent change & 12.5 & 18.4 & 2.0 & 2.3 & 32.9 \\
\hline
\end{tabular}

Sources: Ministry of Finance; and stnff estimates.

1/ In 1993 the tax on the fuel distributors' profits and capital distributions was replaced by the tax on petroleum products.

2/ As of 1998, municipal taxes were collected by the central government and directly passed on to the municipalities. Therefore, they are no longer considered to be "Tax revenue"

3/ Collected by the customs department on imports.

4/ On government-guaranteed external borrowing.

5/ These are the so called contas de ordem, which are revenue as budgeted from the direct provision of services by government agencies offset by the same amounts of current expenditure for each of these agencies 
Table 17. Cape Verde: Selected Indicators of Central Government Revenue, 1994-99

\begin{tabular}{|c|c|c|c|c|c|}
\hline & 1994 & 1995 & 1996 & 1997 & 1998 \\
\hline & \multicolumn{5}{|c|}{ (In millions of Cape Verde escudos) } \\
\hline Tax revenue & 5,590 & 6,408 & 6,961 & 7,479 & 8,409 \\
\hline Of which: taxes on income and profits & 1,978 & 2,201 & 2,521 & 2,844 & 3,068 \\
\hline taxes on international trade & 3,187 & 3,758 & 3,922 & 4,148 & 4,906 \\
\hline Nontax revenue & 1,509 & 1,997 & 1,615 & 1,294 & 3,247 \\
\hline Of which: property income & 208 & 487 & 594 & 367 & 428 \\
\hline transfers & 420 & 425 & 543 & 257 & 256 \\
\hline \multirow{2}{*}{ reimbursement of principal by public enterprises } & 0 & 101 & 0 & 0 & 1,292 \\
\hline & \multicolumn{5}{|c|}{ (In millions of 1990 Cape Verde escudos) } \\
\hline Tax revenue & 4,187 & 4,425 & 4,537 & 4,492 & 4,838 \\
\hline Of which: taxes on income and profits & 1,482 & 1,520 & 1,644 & 1,708 & 1,765 \\
\hline taxes on international trade & 2,387 & 2,595 & 2,557 & 2,492 & 2,823 \\
\hline Nontax revenue & 1.130 & 1,379 & 1,052 & 777 & 1,868 \\
\hline Of which: property income & 155 & 336 & 387 & 220 & 246 \\
\hline transfers & 314 & 293 & 354 & 154 & 147 \\
\hline \multirow[t]{3}{*}{ reimbursement of principal by public enterprises } & 0 & 70 & 0 & 0 & 743 \\
\hline & & (As percen & f budgetary & venue) & \\
\hline & 78.7 & 76.2 & 81.2 & 85.3 & 72.1 \\
\hline Of which: taxes on income and profits & 27.9 & 26.2 & 29.4 & 32.4 & 26.3 \\
\hline taxes on international trade & 44.9 & 44.7 & 45.7 & 47.3 & 42.1 \\
\hline Nontax revenue & 21.3 & 23.8 & 18.8 & 14.7 & 27.9 \\
\hline Of which: property income & 2.9 & 5.8 & 6.9 & 4.2 & 3.7 \\
\hline transfers & 5.9 & 5.1 & 6.3 & 2.9 & 2.2 \\
\hline \multirow[t]{2}{*}{ reimbursement of principal by public enterprises } & 0.0 & 1.2 & 0.0 & 0.0 & 11.1 \\
\hline & \multicolumn{5}{|c|}{ (Annual percentage change) } \\
\hline Tax revenue & 17.2 & 14.6 & 8.6 & 7.5 & 1.1 \\
\hline Of which: taxes on income and profits & 29.9 & 11.3 & 14.6 & 12.8 & -4.6 \\
\hline taxes on international trade & 12.6 & 17.9 & 4.4 & 5.8 & 5.4 \\
\hline Nontax revenue & -1.8 & 32.4 & -19.2 & -19.9 & -5.8 \\
\hline Of which: property income & -43.0 & 134.7 & 22.0 & -38.2 & -38.6 \\
\hline transfers & 29.0 & 1.2 & 27.9 & $-\$ 2.7$ & .52 .4 \\
\hline \multirow[t]{2}{*}{ reimbursement of principal by public enterprises } & $\cdots$ & $\cdots$ & $\ldots$ & $\ldots$ & 29.1 \\
\hline & \multicolumn{5}{|c|}{ (In percent of GDP) } \\
\hline Tax revenue & 16.6 & 16.9 & 17.1 & 16.6 & 17.3 \\
\hline Of which: taxes on income and profits & 5.9 & 5.8 & 6.2 & 6.3 & 6.3 \\
\hline taxes on international trade & 9.5 & 9.9 & 9.7 & 9.2 & 10.1 \\
\hline Nontax revenue & 4.5 & 5.3 & 4.0 & 2.9 & 6.7 \\
\hline Of which: property income & 0.6 & 1.3 & 1.5 & 0.8 & 0.9 \\
\hline transfers & 1.2 & 1.1 & 1.3 & 0.6 & 0.5 \\
\hline reimbursement of principal by public enterprises & 0.0 & 0.3 & 0.0 & 0.0 & 2.7 \\
\hline
\end{tabular}

Sources: Ministry of Finance; and staff estimates. 
Table 18. Cape Verde: Economic Classification of Central Government Expenditure, 1994-98

\begin{tabular}{|c|c|c|c|c|c|}
\hline & 1994 & 1995 & 1996 & 1997 & 1998 \\
\hline & \multicolumn{5}{|c|}{ (In millions of Cape Verde escudos) } \\
\hline Total expenditure & 17,699 & 19,508 & 19,647 & 19,036 & 19,037 \\
\hline Recurrent expenditure & 6,923 & 9,287 & 9,272 & 10,529 & 10,718 \\
\hline Wages and salaries & 3,396 & 3,949 & 4,284 & 4,529 & 4,894 \\
\hline Of which : voluntary departure program & 0 & 0 & 0 & 0 & 243 \\
\hline Goods and services & 281 & 285 & 284 & 619 & 350 \\
\hline Interest on pubiic debt & 341 & 1,208 & 1,493 & 1,832 & 1,893 \\
\hline Domestic 1/ & 68 & 938 & 1,233 & 1,402 & 1,543 \\
\hline Of which: residual from trust fund & $\ldots$ & $\ldots$ & 0 & 0 & $\ldots$ \\
\hline External $2 /$ & 273 & 270 & 260 & 430 & 350 \\
\hline Subsidies and transfers & 1,169 & 1,667 & 1,535 & 2,893 & 2,672 \\
\hline Public enterprises & 0 & 15 & 0 & 0 & 0 \\
\hline Public sector & 959 & 1,443 & 1,346 & 2,521 & 2,391 \\
\hline Other entities & 210 & 208 & 189 & 372 & 281 \\
\hline Other current expenditure & 1,247 & 1,648 & 1,676 & 656 & 710 \\
\hline Capital expenditure & 65 & 71 & 109 & 131 & 20 \\
\hline Other expenditure & 1,182 & 1,577 & 1,567 & 525 & 690 \\
\hline Autonomous expenditure $3 /$ & 489 & 530 & 0 & 0 & 200 \\
\hline Capital expenditure & 10,776 & 10,221 & 10,375 & 8,507 & 8,319 \\
\hline Foreign financing & 6,982 & 6,952 & 7,301 & 6,594 & 7,355 \\
\hline Grants & 5,120 . & 5,602 & 5,411 & 4,750 & 5,241 \\
\hline Loans & 1,862 & 1,350 & 1,890 & 1,844 & 2,114 \\
\hline Domestic resources & 3,794 & 3,269 & 3,074 & 1,913 & 964 \\
\hline \multirow[t]{2}{*}{ Of which: domestic capital participation } & 774 & 623 & 0 & 805 & 64 \\
\hline & \multicolumn{5}{|c|}{ (In percent of total recurrent expenditure) } \\
\hline Recurrent expenditure & 100.0 & 100.0 & 100.0 & 100.0 & 100.0 \\
\hline Wages and salaries & 49.1 & 42.5 & 46.2 & 43.0 & 45.7 \\
\hline Of which : voluntary departure program & 0.0 & 0.0 & 0.0 & 0.0 & 2.3 \\
\hline Goods and services & 4.1 & 3.1 & 3.1 & 5.9 & 3.3 \\
\hline Interest on public debt & 4.9 & 13.0 & 16.1 & 17.4 & 17.7 \\
\hline Domestic 1/ & 1.0 & 10.1 & 13.3 & 13.3 & 14.4 \\
\hline Of which: residual from trust fund & $\ldots$ & $\ldots$ & $\ldots$ & $\ldots$ & $\ldots$ \\
\hline External 2 & 3.9 & 2.9 & 2.8 & 4.1 & 3.3 \\
\hline Subsidies and transfers & 16.9 & 17.9 & 16.6 & 27.5 & 24.9 \\
\hline Public enterprises & 0.0 & 0.2 & 0.0 & 0.0 & 0.0 \\
\hline Public sector & 13.8 & 15.5 & 14.5 & 23.9 & 22.3 \\
\hline Other entities & 3.0 & 2.2 & 2.0 & 3.5 & 2.6 \\
\hline Other current expenditure & 18.0 & 17.7 & 18.1 & 6.2 & 6.6 \\
\hline Capital expenditure & 0.9 & 0.8 & 1.2 & 1.2 & 0.2 \\
\hline Other expenditure & 17.1 & 17.0 & 16.9 & 5.0 & 6.4 \\
\hline \multirow[t]{2}{*}{ Autonomous expenditure $3 /$} & 7.1 & 5.7 & 0.0 & 0.0 & 1.9 \\
\hline & \multicolumn{5}{|c|}{ (In percent of GDP) } \\
\hline Recurrent expenditure & 20.6 & 24.5 & 22.8 & 23.3 & 22.0 \\
\hline Wages and salaries & 10.1 & 10.4 & 10.5 & 10.0 & 10.1 \\
\hline Of which: voluntary departure program & 0.0 & 0.0 & 0.0 & 0.0 & 0.5 \\
\hline Goods and services & 0.8 & 0.8 & 0.7 & 1.4 & 0.7 \\
\hline Interest on public debt & 1.0 & 3.2 & 3.7 & 4.1 & 3.9 \\
\hline $\begin{array}{l}\text { Domestic } 1 / \\
\text { Of which: residual from trust fund }\end{array}$ & $\begin{array}{r}0.2 \\
\ldots\end{array}$ & $\begin{array}{r}2.5 \\
\ldots\end{array}$ & $\begin{array}{r}3.0 \\
\ldots\end{array}$ & $\begin{array}{r}3.1 \\
\ldots\end{array}$ & $\begin{array}{r}3.2 \\
\ldots\end{array}$ \\
\hline External $2 /$ & 0.8 & 0.7 & 0.6 & 1.0 & 0.7 \\
\hline Subsidies and transfers & 3.5 & 4.4 & 3.8 & 6.4 & 5.5 \\
\hline Public enterprises & 0.0 & 0.0 & 0.0 & 0.0 & 0.0 \\
\hline Public sector & 2.8 & 3.8 & 3.3 & 5.6 & 4.9 \\
\hline Other entities & 0.6 & 0.6 & 0.5 & 0.8 & 0.6 \\
\hline Other current expenditure & 3.7 & 4.4 & 4.1 & 1.5 & 1.5 \\
\hline Capital expenditure & 0.2 & 0.2 & 0.3 & 0.3 & 0.0 \\
\hline Other expenditure & 3.5 & 4.2 & 3.9 & 1.2 & 1.4 \\
\hline Autonomous expenditure 3/ & 1.5 & 1.4 & 0.0 & 0.0 & 0.4 \\
\hline
\end{tabular}

Sources: Ministry of Finance; and staff estimates.

1/ Including the debt service to the central bank and the Instituto Nacional de Pprevidencia Social (INPS).

$2 /$ Including central government and public enterprises' debt guaranteed by the central government.

3/ These are the so called contas de ordem, which are revenue as budgeted from the direct provision of services

by goverument agencies offset by the same amounts of current expenditure for each of these agencies 
Table 19. Cape Verde: Public Debt of Central Government, 1994-98

(In millions of Cape Verde escudos)

\begin{tabular}{|c|c|c|c|c|c|}
\hline & 1994 & 1995 & 1996 & 1997 & 1998 \\
\hline Stock of domestic public debt & 11,656 & 13,859 & 16,618 & 17,689 & 17,689 \\
\hline Banking sector & 10,330 & 12,336 & 14,094 & 15,846 & 15,058 \\
\hline Bank of Cape Verde & 4,363 & 4,856 & 5,149 & 5,758 & 5,524 \\
\hline Banco Comercial do Atlantico & 5,967 & 6,989 & 7,781 & 8,502 & 7,904 \\
\hline Caixa Economica de Cabo Verde & 0 & 491 & 1,076 & 1,262 & 1,361 \\
\hline Banco Totta e Acores & 0 & 0 & 87 & 324 & 270 \\
\hline Non-banking sector & 1,326 & 1,523 & 2,525 & 1,843 & 2,631 \\
\hline INPS $1 /$ & 1,248 & 1,467 & 1,813 & 1,037 & 1,109 \\
\hline Garantia & 78 & 56 & 196 & 107 & 192 \\
\hline Other & 0 & 0 & 516 & 698 & 1,329 \\
\hline Long-term debt & 5,995 & 4,788 & 5,369 & 4,037 & 5,524 \\
\hline Bank of Cape Verde & 3,729 & 4,359 & 4,210 & 4,037 & 5,524 \\
\hline Banco Comercial do Atlantico & 940 & 0 & 0 & 0 & 0 \\
\hline Caixa Economica de Cabo Verde & 0 & 0 & 0 & 0 & 0 \\
\hline Banco Totta e Acores & 0 & 0 & 0 & 0 & 0 \\
\hline INPS $1 /$ & 1,248 & 373 & 1,103 & 0 & 0 \\
\hline Garantia & 78 & 56 & 56 & 0 & 0 \\
\hline Other & 0 & 0 & 0 & 0 & 0 \\
\hline Medium-term debt & 5,027 & 7,024 & 7,375 & 8,331 & 8,251 \\
\hline Bank of Cape Verde & 0 & 0 & 0 & 0 & 0 \\
\hline Banco Comercial do Atlantico 2/ & 5,027 & 6,304 & 7,150 & 7,562 & 7,562 \\
\hline Caixa Economica de Cabo Verde & 0 & 0 & 135 & 135 & 135 \\
\hline Banco Totta e Acores & 0 & $\mathbf{0}$ & 50 & 50 & 0 \\
\hline INPS 1/ & 0 & 720 & 0 & 235 & 215 \\
\hline Garantia & 0 & 0 & 0 & 22 & 22 \\
\hline Other & 0 & 0 & 40 & 327 & 317 \\
\hline Short-term debt & 634 & 2,048 & 3,874 & 5,321 & 3,914 \\
\hline Bank of Cape Verde & 634 & 497 & 939 & 1,721 & 0 \\
\hline Banco Comercial do Atlantico & 0 & 686 & 631 & 940 & 342 \\
\hline Caixa Economica de Cabo Verde & 0 & 491 & 941 & 1,127 & 1,226 \\
\hline Banco Totta e Acores & $\mathbf{0}$ & 0 & 37 & 274 & 270 \\
\hline INPS $1 /$ & 0 & 374 & 710 & 802 & 894 \\
\hline Garantia & 0 & 0 & 140 & 85 & 170 \\
\hline Other & 0 & 0 & 476 & 372 & 1,013 \\
\hline
\end{tabular}

Sources: Ministry of Finance; Bank of Cape Verde; and staff estimates.

1/ Instituto Nacional Previdencia Social (INPS).

2/ The debt of 1994 was contracted in connection with the clearing of nonperforming public enterprises' debt held by the Bank of Cape Verde. 
Table 20 Cape Verde: Current Expenditures by Administrative Unit, 1994-98

\begin{tabular}{|c|c|c|c|c|c|}
\hline & 1994 & 1995 & 1996 & 1997 & 1998 \\
\hline & \multicolumn{5}{|c|}{ (In millions of Cape Verde escudos) } \\
\hline National Assembly & 115 & 121 & 137 & 187 & 276 \\
\hline Presidency & 56 & 71 & 81 & 81 & 86 \\
\hline Office of the Prime Minister & 63 & 63 & 66 & 64 & 88 \\
\hline Ministries & 6,592 & 8,383 & 10,906 & 10,879 & 10,259 \\
\hline Presidency of the Ministry Council & 439 & 449 & 449 & 80 & 61 \\
\hline Assistant to the Prime Minister & 0 & 0 & 0 & 197 & 218 \\
\hline Agriculture and Rural Development & 247 & 127 & 127 & 256 & 220 \\
\hline Defense & 281 & 477 & 352 & 382 & 443 \\
\hline Economic Coordination/Finance & 1,485 & 2,949 & 5,370 & 5,093 & 3,954 \\
\hline Education & 1,511 & 1,810 & 2,079 & 2,206 & 2,544 \\
\hline Foreign Affairs & 495 & 550 & 689 & 708 & 739 \\
\hline Health & 721 & 772 & 821 & 943 & 1,074 \\
\hline Infrastructure and Transportation & 224 & 119 & 120 & 117 & 106 \\
\hline Justice and Labor & 943 & 1,005 & 772 & 788 & 803 \\
\hline Sea & 247 & 127 & 128 & 109 & 97 \\
\hline \multirow[t]{2}{*}{ Total } & 6,826 & 8,637 & 11,190 & 11,211 & 10,709 \\
\hline & \multicolumn{5}{|c|}{ (In percent of total) } \\
\hline National Assembly & 1.7 & 1.4 & 1.2 & 1.7 & 2.6 \\
\hline Presidency & 0.8 & 0.8 & 0.7 & 0.7 & 0.8 \\
\hline Office of the Prime Minister & 0.9 & 0.7 & 0.6 & 0.6 & 0.8 \\
\hline Ministries & 96.6 & 97.1 & 97.5 & 97.0 & 95.8 \\
\hline Presidency of the Ministry Council & 6.4 & 5.2 & 4.0 & 0.7 & 0.6 \\
\hline Assistant to the Prime Minister & 0.0 & 0.0 & 0.0 & 1.8 & 2.0 \\
\hline Agriculture and Rural Development & 3.6 & 1.5 & 1.1 & 2.3 & 2.0 \\
\hline Defense & 4.1 & 5.5 & 3.1 & 3.4 & 4.1 \\
\hline Economic Coordination/Finance & 21.8 & 34.1 & 48.0 & 45.4 & 36.9 \\
\hline Education & 22.1 & 21.0 & 18.6 & 19.7 & 23.8 \\
\hline Foreign Affairs & 7.2 & 6.4 & 6.2 & 6.3 & 6.9 \\
\hline Health & 10.6 & 8.9 & 7.3 & 8.4 & 10.0 \\
\hline Infrastructure and Transportation & 3.3 & 1.4 & 1.1 & 1.0 & 1.0 \\
\hline Justice and Labor & 13.8 & 11.6 & 6.9 & 7.0 & 7.5 \\
\hline Sea & 3.6 & 1.5 & 1.1 & 1.0 & 0.9 \\
\hline Total & 100.0 & 100.0 & 100.0 & 100.0 & 100.0 \\
\hline
\end{tabular}

Sources: Ministry of Finance; and staff estimates. 
Table 21. Cape Verde: Monetary Survey, 1993-98

\begin{tabular}{|c|c|c|c|c|c|c|c|c|c|}
\hline & \multirow[t]{2}{*}{1993} & \multirow[t]{2}{*}{1994} & \multirow[t]{2}{*}{1995} & \multirow[t]{2}{*}{1996} & \multirow[t]{2}{*}{1997} & \multicolumn{4}{|c|}{1998} \\
\hline & & & & & & Mar. & Jun. & Sep. & Dec. \\
\hline & \multicolumn{9}{|c|}{ In millions of Cape Verde escudos } \\
\hline Net foreign assets & 6,172 & 5,934 & 5,207 & 6,811 & 5,613 & 5,737 & 5,949 & 5,149 & 5,646 \\
\hline Central bank & 5,140 & 3,644 & 4,718 & 4,540 & 4,272 & 4,331 & 4,472 & 3,667 & 3,496 \\
\hline Net foreign assets, excl. medium- and long-term liabilities & 5,353 & 3,778 & 4,783 & 4,590 & 4,304 & 4,363 & 4,504 & 3,700 & 3,529 \\
\hline Liquid assets (net) & 2,533 & 1,168 & 2,421 & 2,099 & 1,642 & 1,773 & 1,835 & 1,297 & 1,253 \\
\hline Other & 2,608 & 2,476 & 2,298 & 2,491 & 2,662 & 2,558 & 2,636 & 2,370 & 2,244 \\
\hline Medium- and long-term foreign liabilities & .213 & -134 & -65 & -50 & -32 & -32 & -32 & -32 & -32 \\
\hline Commercial banks & 1,032 & 2,290 & 489 & 2,271 & 1,341 & 1,406 & 1,478 & 1,482 & 2,150 \\
\hline Net foreign assets, excl. medium- and long-term liabilities & 1,032 & 2,319 & 646 & 2,508 & 1,822 & 1,920 & 1,948 & 1,945 & 2,557 \\
\hline Medium- and long-term foreign liabilities & 0 & .29 & -157 & -237 & -481 & -513 & -471 & .463 & -407 \\
\hline Net domestic assets & 11,780 & 14,859 & 19,903 & 20,282 & 24,764 & 24,265 & 24,835 & 24,849 & 25,272 \\
\hline Domestic credit & 12,343 & 16,183 & 20,897 & 23,043 & 27,712 & 28,031 & 29,564 & 30,198 & 29,404 \\
\hline Net claims on the govermment & 2,262 & 8,046 & 9,978 & 11,447 & 13,126 & 13,084 . & 14,056 & 14,229 & 13,079 \\
\hline Claims on the central government & 4,569 & 9,813 & 11,845 & 14,129 & 15,846 & 16,011 & 16,719 & 16,461 & 15,583 \\
\hline Net of deposits other than project deposits & 4,282 & 9,540 & 11,599 & 13,342 & 15,515 & 15,933 & 16,631 & 16,384 & 15,500 \\
\hline Claims on local government & 35 & 295 & 83 & 109 & 120 & $120^{\circ}$ & 131 & 130 & 130 \\
\hline Claims on other govermment agencies & 1,939 & 1,082 & 1,258 & 158 & 155 & 155 & 155 & 151 & 151 \\
\hline Deposits & $-4,281$ & $-3,144$ & $-3,209$ & $-2,949$ & $-2,995$ & $-3,202$ & $-2,947$ & $-2,513$ & $-2,784$ \\
\hline UJ whicn: project aeposits & -46 & .116 & -281 & -337 & -987 & -894 & -774 & -336 & -345 \\
\hline Credit to the economy & 10,081 & 8,137 & 10,919 & 11,596 & 14,587 & 14,947 & 15,507 & 15,969 & 16,325 \\
\hline Public enterprises & 2,571 & 552 & 617 & 433 & 370 & 375 & 405 & 425 & 440 \\
\hline Private enterprises & 7,510 & 7,585 & 10,303 & 11,164 & 14,217 & 14,571 & 15,102 & 15,544 & 15,885 \\
\hline Other items (net) & .563 & $-1,324$ & -994 & $-2,762$ & $-2,949$ & $-3,766$ & $-4,729$ & $-5,349$ & $-4,132$ \\
\hline Broad money & 17,739 & 20,629 & 24,888 & 27,093 & 30,377 & 30,002 & 30,784 & 29,998 & 30,918 \\
\hline Currency in circulation & 3,549 & 3,930 & 4,640 & $.4,520$ & 4,854 & 4,542 & 4,632 & 4,459 & 5,060 \\
\hline Demand deposits & 5,495 & 6,683 & 8,131 & 8,487 & 10,666 & 10,504 & 11,115 & 10,424 & 10,396 \\
\hline Time deposits & 8,333 & 9,887 & 11,947 & 13,692 & 13,965 & 14,199 & 14,304 & 14,447 & 14,632 \\
\hline Foreign exchange deposits (residents) & 361 & 130 & 171 & 138 & 526 & 527 & 534 & 424 & 575 \\
\hline \multirow[t]{2}{*}{ Repurchase agreements } & 0 & 0 & 0 & 256 & 366 & 232 & 200 & 244 & 256 \\
\hline & \multicolumn{9}{|c|}{ (Changes in percent of beginning-of-period money stock) } \\
\hline Net foreign assets & 3.8 & -1.3 & -3.5 & 6.4 & -4.4 & 0.4 & 1.1 & -1.5 & 0.1 \\
\hline Net domestic assets & 12.1 & 17.4 & 24.5 & 1.5 & 16.5 & -1.6 & 0.2 & 0.3 & 1.7 \\
\hline Domestic credit & 9.2 & 21.6 & 22.8 & 8.6 & 17.2 & 1.0 & 6.1 & 8.2 & 5.6 \\
\hline Claims on the general govemment & 5.4 & 32.6 & 9.4 & 5.9 & 6.2 & -0.1 & 3.1 & 3.6 & -0.2 \\
\hline Claims on the central government & $\ldots$ & 29.6 & 9.9 & 9.2 & 6.3 & 0.5 & 2.9 & 2.0 & -0.9 \\
\hline Credit to the economy & 3.8 & -11.0 & 13.5 & 2.7 & 11.0 & 1.2 & 3.0 & 4.5 & 5.7 \\
\hline Broad money & 15.9 & 16.3 & 20.6 & 8.9 & 12.1 & -1.2 & 1.3 & -1.2 & 1.8 \\
\hline
\end{tabular}

Sources: Bark of Cape Verde; and staff estimates. 
Table 22. Cape Verde: Summary Accounts of the Bank of Cape Verde, $1994-98$ (In millions of Cape Verde escudos; end of period)

\begin{tabular}{|c|c|c|c|c|c|c|c|c|}
\hline & \multirow[t]{2}{*}{1994} & \multirow[t]{2}{*}{1995} & \multirow[t]{2}{*}{1996} & \multirow[t]{2}{*}{1997} & \multicolumn{4}{|c|}{1998} \\
\hline & & & & & Mar. & Jun. & Sep. & Dec. \\
\hline Net foreign assets & 3,644 & 4,718 & 4,540 & 4,272 & 4,331 & 4,472 & 3,667 & 3,496 \\
\hline Gross foreiga assets & 3,693 & 4,765 & 4,641 & 4,362 & 4,422 & 4,563 & 3,756 & 3,585 \\
\hline Short-term assets & 1,217 & 2,467 & 2,150 & 1,700 & 1,831 & 1,894 & 1,354 & 1,309 \\
\hline Porejgn notes and coins & 1 & 5 & 29 & 22 & 21 & 18 & 18 & 39 \\
\hline Funds denominated in foreign currency & 1,211 & 2,461 & 2,116 & 1,675 & 1,809 & 1,876 & 1,330 & 1,264 \\
\hline Demand deposits & 522 & 522 & 522 & 810 & 686 & 329 & 751 & 454 \\
\hline Time deposits & 388 & 388 & 388 & 674 & 934 & 1,359 & 391 & 286 \\
\hline Foreign-currency titles & 4 & 4 & 4 & 4 & 0 & 0 & 0 & 0 \\
\hline Others & 297 & 1,547 & 1,202 & 188 & 188 & 188 & 188 & 525 \\
\hline SDR holdings & 5 & l & 6 & 3 & 1 & 0 & 6 & 5 \\
\hline Reserve position with the Fund & 0 & 0 & 0 & 0 & 0 & o & $\mathbf{0}$ & 0 \\
\hline Medium- and long-term assets & 2,476 & 2,298 & 2,491 & 2,662 & 2,590 & 2,669 & 2,402 & 2,276 \\
\hline Investments abroad & 1,636 & 1,542 & 1,694 & 1,806 & 1,772 & 1,835 & 1,620 & 1,503 \\
\hline Payments agreoments & 559 & 479 & 588 & 649 & 606 & 621 & 570 & 561 \\
\hline Intemational organizations & 281 & 276 & 208 & 208 & 208 & 208 & 208 & 208 \\
\hline Other & 0 & 0 & 0 & 0 & 4 & 4 & 4 & 4 \\
\hline Short-term foreign liabilities & -49 & -47 & -51 & -58 & -59 & .59 & -57 & -57 \\
\hline Use of Fund credit & 0 & 0 & 0 & 0 & 0 & 0 & 0 & 0 \\
\hline Other & -49 & -47 & -51 & -58 & -59 & .59 & -57 & -57 \\
\hline Medium- and long-term foreign liabilities & -134 & -65 & -50 & -32 & -32 & .32 & .32 & .32 \\
\hline Loans & -103 & -33 & -18 & 0 & 0 & 0 & 0 & 0 \\
\hline Deposits of international organizations & -32 & -32 & -32 & -32 & -32 & -32 & -32 & -32 \\
\hline Net domestic assets & 7,428 & 8,371 & 8,121 & 8,713 & 8,556 & 8,771 & 8,991 & 10,450 \\
\hline Domestic credit & 5,967 & 6,443 & 6,726 & 6,579 & 6,703 & 7,187 & 7,468 & 6,584 \\
\hline Net claims on general govenument & 4,173 & 4,712 & 5,017 & 4,908 & 5,033 & 5,661 & 5,971 & 5,099 \\
\hline Central government (net) & 4,342 & 4,857 & 5,149 & 5,758 & 5,886 & 6,506 & 6,539 & 5,524 \\
\hline Claims & 4,363 & 4,857 & 5,149 & 5,758 & 5,886 & 6,506 & 6,539 & 5,524 \\
\hline Advances to the treasury & 634 & 497 & 939 & 0 & 0 & 0 & 0 & 0 \\
\hline Public enterprise debt & 0 & 3,105 & 4,211 & 5,758 & 5,758 & 5,758 & 5,758 & 5,524 \\
\hline Other claims & 3,729 & 1,255 & 0 & 0 & 128 & 747 & 781 & 0 \\
\hline Central govemment deposits (trs & -21 & 0 & 0 & 0 & 0 & 0 & 0 & 0 \\
\hline Deposits in foreign currency & 0 & o & -2 & -49 & -168 & .180 & -311 & -278 \\
\hline Other government deposits & -273 & -246 & -229 & -895 & -780 & .760 & -348 & -239 \\
\hline Project deposits & 0 & 0 & 0 & -702 & -591 & -578 & -166 & -64 \\
\hline Other (IDA credit line) & -273 & -246 & -229 & -194 & -190 & -182 & -182 & -175 \\
\hline Claims on local government & 0 & $\mathbf{0}$ & 0 & 0 & 0 & 0 & 0 & 0 \\
\hline Net claims on other goversment agencie & 104 & 101 & 98 & 95 & 95 & 95 & 91 & 91 \\
\hline Clains on the Trust fund & 0 & o & 0 & $\mathbf{0}$ & o & 1,357 & 1,782 & 2,755 \\
\hline Claims on commercial banks $1 /$ & 583 & 574 & 546 & 520 & sis & 371 & 362 & 362 \\
\hline Credit to the economy & 1,211 & 1,157 & 1,163 & 1,152 & 1,156 & 1, iss & 1,135 & 1,124 \\
\hline Credit to nonfinancial public enterprises & 120 & 119 & 114 & 0 & 0 & 0 & 0 & 0 \\
\hline Credit to the private sector & 1,091 & 1,038 & 1,049 & 1,152 & 1,156 & 1,155 & 1,135 & 1,124 \\
\hline Other items & 1,461 & 1,928 & 1,395 & 2,134 & 1,853 & 1,584 & 1,523 & 3,866 \\
\hline Monetary liabilities & $-8,860$ & $-10,757$ & $-9,997$ & $-10,041$ & $-9,805$ & $-10,141$ & $-9,538$ & $-10,977$ \\
\hline Monetary base & $-8,686$ & $-10,656$ & $-9,983$ & $-10,035$ & $.9,802$ & $-10,14 !$ & $-9,536$ & $-10,971$ \\
\hline Currency issued & $-4,552$ & $-5,659$ & $-5,195$ & $-5,643$ & $-5,349$ & $-5,216$ & $-5,239$ & $-5,834$ \\
\hline Currency in circulation & $-3,930$ & $-4,640$ & $-4,520$ & $-4,854$ & $-4,542$ & $-4,632$ & $-4,459$ & $-5,060$ \\
\hline Cash held by the treasury & 0 & 0 & 0 & $\mathbf{0}$ & 0 & 0 & 0 & 0 \\
\hline Cash held by the banks & -622 & $-1,019$ & -675 & .789 & -807 & .584 & .780 & -774 \\
\hline Deposits of monetary institutions (BCV) I/ & $-4,134$ & $-4,997$ & $-4,788$ & $-4,392$ & $-4,453$ & $-4,925$ & $.4,297$ & $-5,137$ \\
\hline Demand deposits & 0 & 0 & 0 & 0 & 0 & 0 & 0 & 0 \\
\hline Deposits of nonfinancial public enterprises & -174 & -101 & 0 & 0 & 0 & o & 0 & 0 \\
\hline Other liabilities & 0 & 0 & -15 & -6 & -3 & 0 & -3 & -6 \\
\hline Capital account & 2,078 & 2,268 & 2,663 & 2,945 & 3,082 & 3,102 & 3,120 & 2,969 \\
\hline Capital & 500 & 500 & 200 & 200 & 200 & 200 & 200 & $\cdot 200$ \\
\hline Reserves & 71 & 71 & 71 & 71 & 75 & 75 & 75 & 75 \\
\hline Provisions & 1,640 & 1,931 & 2,303 & 2,650 & 2,783 & 2,802 & 2,820 & 2,601 \\
\hline Goins and losses & .133 & -234 & 89 & 25 & 25 & 25 & 25 & 93 \\
\hline
\end{tabular}

Sources: Bank of Cape Verde (BCV); and staff estimates.

1/ The banks' figure includes the Banco Comercial do Atlantico, Caixa Economica de Cabo Verde, and Banco Totta e Acores, and Caixa Geral de Depositos. 
Table 23. Cape Verde: Summary Accounts of the Commercial Banks, 1996-98

(In milions of Cape Verde escudos)

\begin{tabular}{|c|c|c|c|c|c|c|}
\hline & \multirow[t]{2}{*}{1996} & \multirow[t]{2}{*}{1997} & \multicolumn{4}{|c|}{1998} \\
\hline & & & Mar. & Jun. & Sep. & Dec. \\
\hline Net foreign assets & 2,271 & 1,341 & 1,406 & 1,478 & 1,482 & 2,150 \\
\hline Gross foreign assets & 2,760 & 2,289 & 2,465 & 2,554 & 2,594 & 3,149 \\
\hline Short-term foreign liabilities & -251 & -468 & -545 & -606 & -649 & -592 \\
\hline Nonresident deposits & -251 & -468 & -545 & .595 & -649 & -554 \\
\hline Others & 0 & 0 & 0 & -11 & 0 & -38 \\
\hline Medium- and long-term foreign liabilities & -237 & -481 & -513 & -471 & -463 & -407 \\
\hline Domestic assets & 27,769 & 31,787 & 32,113 & 32,367 & 31,780 & 32,632 \\
\hline Bank reserves & 5,466 & 5,701 & 5,292 & 5,435 & 5,061 & 5,817 \\
\hline Vault cash & 675 & 789 & 807 & 584 & 780 & 774 \\
\hline Deposits with central bank & 4,791 & 4,912 & 4,485 & 4,851 & 4,282 & 5,043 \\
\hline Interbank deposits & 56 & 194 & 212 & 120 & 140 & 102 \\
\hline Domestic credit & 19,582 & 23,703 & 24,096 & 24,756 & 24,945 & 25,449 \\
\hline Claims on general government. & 9,149 & 10,268 & 10,305 & 10,404 & 10,112 & 10,248 \\
\hline Claims on central government & 8,980 & 10,088 & 10,125 & 10,213 & 9,921 & 10,058 \\
\hline Claims on local government & 109 & 120 & 120 & 131 & 130 & 130 \\
\hline Claims on other government agencies & 60 & 60 & 60 & 60 & 60 & 60 \\
\hline Claims on the trust fund & 0 & 0 & 0 & 0 & 0 & 0 \\
\hline Credit to the economy & 10,433 & 13,435 & 13,791 & 14,352 & 14,834 & 15,201 \\
\hline Public enterprises & 319 & 370 & 375 & 405 & 425 & 440 \\
\hline Private enterprises & 10,114 & 13,065 & 13,416 & 13,947 & 14,409 & 14,761 \\
\hline Other items (net) & 2,666 & 2,189 & 2,513 & 2,056 & 1,634 & 1,264 \\
\hline Domestic liabilities & $-26,678$ & $-28,701$ & $-28,768$ & $-29,058$ & $-28,311$ & $-29,417$ \\
\hline Interbank deposits & -67 & -10 & -12 & .6 & -25 & -41 \\
\hline General government deposits & $-2,718$ & $-2,013$ & $-2,179$ & $-1,933$ & $-1,741$ & $-2,155$ \\
\hline Central government (treasury) & -787 & -331 & -79 & -88 & .77 & -83 \\
\hline Foreign-currency deposits & -165 & -120 & -110 & -55 & -172 & 0 \\
\hline Project deposits & -337 & -285 & -303 & -196 & -170 & -281 \\
\hline Local govemments' deposits & -390 & -176 & -174 & -250 & -171 & -186 \\
\hline Other government agencies & $-1,040$ & $-1,101$ & $-1,514$ & $-1,344$ & $-1,151$ & $-1,605$ \\
\hline INPS & -727 & -587 & -675 & -605 & -526 & -733 \\
\hline Other & -314 & -514 & -839 & -739 & -625 & -872 \\
\hline Demand deposits & $-8,850$ & $-10,955$ & $-10,783$ & $-11,384$ & $-10,703$ & $-10,674$ \\
\hline Nonmonetary financial institutions & $-1,721$ & $-1,479$ & $-1,272$ & $-1,170$ & -866 & -777 \\
\hline Nonfinancial public enterprises & -91 & -59 & -98 & -156 & -192 & -265 \\
\hline Private sector & $-6,307$ & $-8,406$ & $-8,292$ & $-8,910$ & $-8,645$ & $-8,598$ \\
\hline Emigrants & .369 & -722 & -842 & -879 & -721 & -757 \\
\hline Other $2 /$ & -362 & -289 & -280 & -269 & -279 & -278 \\
\hline Time deposits & $-14,103$ & $-14,274$ & $-14,447$ & $-14,556$ & $-14,700$ & $-15,242$ \\
\hline Savings deposits & -539 & -670 & -711 & -739 & -856 & -907 \\
\hline Nonmonetary financial institutions & -49 & -46 & -31 & -25 & -30 & -30 \\
\hline Nonfinancial public enterprises & -64 & -40 & -37 & -36 & -36 & -36 \\
\hline Private sector & $-6,817$ & $-6,600$ & $-6,592$ & $-6,501$ & $-6,525$ & $-6,406$ \\
\hline Emigrants & $-6,223$ & $-6,609$ & $-6,828$ & $-7,003$ & $-7,000$ & $-7,254$ \\
\hline Other $2 /$ & -411 & -309 & -248 & -252 & -254 & -610 \\
\hline Foreign exchange deposits (residents) & -138 & -526 & -527 & -534 & -424 & -575 \\
\hline Bond agreements & -256 & -366 & -232 & -200 & -244 & -256 \\
\hline Central bank refinancing & -546 & -520 & -515 & -371 & -362 & -362 \\
\hline INPS refinancing & 0 & .38 & -75 & -75 & -113 & -113 \\
\hline Capital account & 3,363 & 4,426 & 4,751 & 4,787 & 4,951 & 5,366 \\
\hline Capital & 1,648 & 1,648 & 1,948 & 1,948 & 1,948 & 1,948 \\
\hline Reserves and provisions & 1,269 & 2,415 & 2,440 & 2,476 & 2,639 & 2,677 \\
\hline Gains and losses & 446 & 364 & 364 & 364 & 364 & 741 \\
\hline
\end{tabular}

Source: Bank of Cape Verde.

$1 /$ Instituto Nacional de Previdencia Social (INPS).

2' Deposits utside M2. 
Table 24. Cape Verde: Summary Accounts of the Banco Comercial do Atlantico, 1996-98 (In millions of Cape Verde escudos)

\begin{tabular}{|c|c|c|c|c|c|c|}
\hline & \multirow[t]{2}{*}{1996} & \multirow[t]{2}{*}{1997} & \multicolumn{4}{|c|}{1998} \\
\hline & & & Mar. & Jun. & Sep. & Dec. \\
\hline Net foreign assets & 2,249 & 1,530 & 1,427 & 1,198 & 1,333 & 1,854 \\
\hline Gross forcign assets & 2,606 & 2,092 & 2,055 & 1,865 & 2,029 & 2,451 \\
\hline Short-term foreign assets & 2,307 & 1,798 & 1,746 & 1,557 & 2,029 & 2,451 \\
\hline Other foreign assets & 299 & 294 & 309 & 308 & $\mathbf{0}$ & $\mathbf{0}$ \\
\hline Short-term foreign liabilities & -234 & -439 & -502 & .545 & -577 & -483 \\
\hline Nonresident deposits & -234 & -439 & -502 & -545 & -577 & -445 \\
\hline Others & $\mathbf{0}$ & $\mathbf{0}$ & 0 & $\mathbf{0}$ & $\mathbf{0}$ & -38 \\
\hline Medium- and long-term foreign liabilitics & -123 & -123 & -125 & -122 & -118 & -114 \\
\hline Domestic assets & $22 ; 721$ & 25,058 & 24,783 & 25,020 & 24,109 & 24,236 \\
\hline Bank reserves & 4,248 & 4,754 & 3,914 & 4,318 & 3,719 & 4,219 \\
\hline Vault cash & 530 & 651 & 614 & 444 & 535 & 430 \\
\hline Deposits with central bank & 3,718 & 4,103 & 3,300 & 3,874 & 3,184 & 3,790 \\
\hline Deposits with other monetary institutions & 7 & 18 & 69 & 7 & 7 & 7 \\
\hline Domestic credit & 16,062 & 18,395 & 18,653 & 18,765 & 19,010 & 19,219 \\
\hline Claims on central government (treasury) & 7,817 & 8,502 & 8,557 & 8,198 & 8,087 & 7,904 \\
\hline Claims on local government & 109 & 120 & 120 & 120 & 120 & 120 \\
\hline Claims on other government agencies & 60 & 60 & 60 & 60 & 60 & 60 \\
\hline Credit to the economy & 8,076 & 9,712 & 9,916 & 10,388 & 10,743 & 11,136 \\
\hline Public enterprises & 319 & 370 & 375 & 405 & 425 & 440 \\
\hline Private enterprises & 7,758 & 9,342 & 9,541 & 9,983 & 10,318 & 10,696 \\
\hline Other items & 2,404 & 1,892 & 2,148 & 1,930 & 1,372 & 791 \\
\hline Domestic liabilities & $-22,706$ & $-23,644$ & $-23,255$ & $-23,254$ & $-22,346$ & $-22,688$ \\
\hline Other banks' deposits & -62 & -4 & -6 & 0 & 0 & $\mathbf{0}$ \\
\hline General government deposits & $-2,455$ & $-1,356$ & $-1,497$ & $-1,188$ & $-1,053$ & $-1,190$ \\
\hline Central govemment (treasury) & -787 & -250 & -50 & -40 & -30 & -30 \\
\hline Foreign-currency deposits & -165 & -118 & -108 & -53 & -172 & 0 \\
\hline Project deposits & -337 & -150 & -180 & -128 & -100 & -140 \\
\hline Local governments' deposits & -368 & -170 & -164 & -240 & -160 & -170 \\
\hline Other government agencies & -799 & -668 & -995 & -726 & -590 & -850 \\
\hline DPS $1 /$ & -485 & -298 & -325 & -129 & -65 & -60 \\
\hline Other & -314 & -370 & -670 & -597 & -525 & -790 \\
\hline Demand deposits & $-7,412$ & $-9,269$ & $-8,773$ & $-9,257$ & $-8,614$ & $-8,250$ \\
\hline Nonmonetary tinancial institutions & $-1,713$ & $-1,400$ & $-1,200$ & $-1,160$ & -850 & -770 \\
\hline Nonfinancial public enterprises & 0 & 0 & 0 & 0 & $\mathbf{0}$ & $\mathbf{0}$ \\
\hline Private sector & $-4,998$ & $-6,896$ & $-6,496$ & $-6,992$ & $-6,819$ & $-6,506$ \\
\hline Emigrants & -359 & +699 & -810 & -843 & -674 & -692 \\
\hline Other 21 & -343 & -274 & -267 & .262 & -271 & -282 \\
\hline Time deposits & $-12,377$ & $-12,265$ & $-12,262$ & $-12,336$ & $-12,245$ & $-12,684$ \\
\hline Nonmonetary financial institutions & 0 & 0 & 0 & $\mathbf{0}$ & 0 & 0 \\
\hline Nonfinancial public enterprises & -58 & -30 & -30 & -30 & -30 & -30 \\
\hline Private sector & $-5,736$ & $-5,444$ & $-5,334$ & $-5,292$ & $-5,268$ & $-5,185$ \\
\hline Emigrants & $-6,172$ & $-6,482$ & $-6,650$ & $-6,766$ & $-6,705$ & $-6,863$ \\
\hline Other 2 & -411 & -309 & -248 & -249 & -241 & -607 \\
\hline Foreign exchange deposits (residents) & -115 & -478 & -450 & -336 & -306 & -435 \\
\hline Central bank refinancing & -286 & -273 & -267 & -137 & -129 & -129 \\
\hline Capital account & 2,264 & 2,944 & 2,955 & 2,964 & 3,097 & 3,402 \\
\hline Capital & 1,000 & 1,000 & 1,000 & 1,000 & 1,000 & 1,000 \\
\hline Reserves and provisions & 909 & 1,721 & 1,733 & 1,741 & 1,874 & 1,875 \\
\hline Gains and losses & 355 & 222 & 222 & 222 & 222 & 527 \\
\hline
\end{tabular}

Source: Banco Comercial do Atlantico.

1/ Instituto Nacional de Previdencia Social (INPS)

2/ Deposits outside M2. 
Table 25. Cape Verde: Summary Accounts of the Caixa Economica de Cabo Verde, 1996-98

(In millions of Cape Verdean escudos; end of period)

\begin{tabular}{|c|c|c|c|c|c|c|}
\hline & \multirow[t]{2}{*}{1996} & \multirow[t]{2}{*}{1997} & \multicolumn{4}{|c|}{1998} \\
\hline & & & Mar. & Jun. & Sep. & Dec. \\
\hline Net foreign assets & 37 & .179 & -146 & 16 & -23 & 13 \\
\hline Gross foreign assets & 118 & 152 & 208 & 376 & 289 & 305 \\
\hline Short-term foreign liabilities & 0 & 0 & 0 & -11 & 0 & 0 \\
\hline Nonresident deposits & 0 & 0 & 0 & 0 & 0 & 0 \\
\hline Others & 0 & 0 & 0 & -11 & 0 & 0 \\
\hline Medium- and long-term foreign liabilities & -81 & .332 & -354 & -349 & -312 & -292 \\
\hline Domestic assets & 4,372 & 5,745 & 5,874 & 5,806 & 5,857 & 6,426 \\
\hline Bank reserves & 702 & 718 & 789 & 728 & 733 & 1,005 \\
\hline Vault cash & 69 & 102 & 113 & 100 & 175 & 189 \\
\hline Deposits with central bank & 633 & 617 & 676 & 628 & 558 & 815 \\
\hline Deposits with other monetary institutions & 48 & 172 & 143 & 111 & 125 & 54 \\
\hline Domestic credit & 3,419 & 4,675 & 4,641 & 4,831 & 4,811 & 5,034 \\
\hline Claims on central govemment (treasury) & 1,076 & 1,262 & 1,149 & 3.251 & 1,123 & 1,361 \\
\hline Claims on local government & 0 & 0 & 0 & 11 & 10 & 10 \\
\hline Claims on other government agencies & 0 & 0 & 0 & 0 & 0 & 0 \\
\hline Credit to the economy & 2,343 & 3,413 & 3,492 & 3,569 & 3,678 & 3,664 \\
\hline Public enterprises & 0 & 0 & 0 & 0 & 0 & 0 \\
\hline Private enterprises & 2,343 & 3,413 & 3,492 & 3,569 & 3,678 & 3,664 \\
\hline Other items & 202 & 180 & 300 & 136 & 188 & 334 \\
\hline Domestic liabilities & $-3,590$ & $-4,373$ & $-4,518$ & $-4,587$ & $-4,572$ & $-5,107$ \\
\hline Other banks' deposits & -6 & -6 & -6 & -6 & -25 & -41 \\
\hline General goverument deposits & -264 & -657 & -672 & -737 & -681 & -961 \\
\hline Central government deposits (treasury) & 0 & -81 & -19 & -39 & -39 & -49 \\
\hline Foreign-currency deposits & 0 & -2 & -2 & -2 & 0 & 0 \\
\hline Project deposits & 0 & -135 & -123 & -68 & -70 & -141 \\
\hline Local govemments' deposits & -22 & -6 & -10 & -10 & -11 & -16 \\
\hline Deposits of other government agencies & -242 & -433 & .518 & .618 & -561 & -755 \\
\hline INPS & .242 & .289 & -349 & -476 & -461 & -673 \\
\hline Other & 0 & .144 & -169 & -142 & -100 & -82 \\
\hline Demand deposits & $-1,189$ & $-1,228$ & $-1,318$ & $-1,310$ & $-1,058$ & $-1,161$ \\
\hline Nonmonetary financial institutions & .8 & -79 & -72 & -10 & -16 & -7 \\
\hline Nonfinancial public enterprises & -91 & -59 & -98 & -156 & -192 & -265 \\
\hline Private sector & $-1,075$ & $-1,063$ & $-1,114$ & $-1,116$ & -818 & .864 \\
\hline Emigrants & -6 & -16 & -21 & -23 & -25 & .34 \\
\hline Other $2 /$ & -8 & -11 & -12 & -6 & -7 & 8 \\
\hline Savings deposits & -539 & -670 & -711 & -739 & -856 & .907 \\
\hline Tine deposits & $-1,054$ & $-1,146$ & -1.247 & $-1,275$ & $-1,353$ & $-1,426$ \\
\hline Nonmonetary financial institutions & .49 & -46 & -31 & -25 & -30 & -30 \\
\hline Nonfinancial public enterprises & -6 & -10 & -7 & -6 & -6 & -6 \\
\hline Private sector & -953 & -975 & $-1,043$ & $-1,021$ & $-1,030$ & $-1,010$ \\
\hline Emigrants & .47 & -115 & -166 & -223 & -288 & .381 \\
\hline Other 2f & 0 & 0 & 0 & 0 & 0 & 0 \\
\hline Foreign exchange deposits (residents) & -23 & -16 & -12 & -11 & -9 & -10 \\
\hline Bond agreements & -256 & -366 & -232 & -200 & -244 & .256 \\
\hline Central bank refinancing & -260 & -247 & -247 & -234 & -233 & -233 \\
\hline INPS refinancing & 0 & -38 & -75 & -75 & -113 & -113 \\
\hline Capital account & 819 & 1,193 & 1,209 & 1,235 & 1,263 & 1,332 \\
\hline Capital & 348 & 348 & 348 & 348 & 348 & 348 \\
\hline Reserves and provisions & 360 & 686 & 703 & 729 & 756 & 792 \\
\hline Reserves & 184 & 426 & 426 & 446 & 445 & 481 \\
\hline Provisions & 176 & 260 & 276 & 282 & 312 & 311 \\
\hline Gains and losses & 111 & 159 & 159 & 159 & 159 & 192 \\
\hline
\end{tabular}

Source: Caixa Economica de Cabo Verdc (CECV).

1/ Instituto Nacional de Previdencia Social (INPS).

2/Deposits outside M2 
Table 26. Cape Verde: Summary Accounts of the Banco Totta e Acores, 1996-98 (In millions of Cape Verde escudos)

\begin{tabular}{|c|c|c|c|c|c|c|}
\hline & \multirow[t]{2}{*}{1996} & \multirow[t]{2}{*}{1997} & \multicolumn{4}{|c|}{1998} \\
\hline & & & Mar. & Jun. & Sep. & Dec. \\
\hline Net foreign assets & -14 & -10 & 38 & 228 & 115 & 105 \\
\hline Gross foreign assets & 36 & 45 & 111 & 267 & 199 & 187 \\
\hline Short-term foreign liabilities & -17 & -28 & -38 & -38 & -51 & -82 \\
\hline Nonresident deposits & -17 & -28 & -38 & -38 & -51 & -82 \\
\hline Others & $\mathbf{0}$ & $\mathbf{0}$ & $\mathbf{0}$ & $\mathbf{0}$ & 0 & $\mathbf{0}$ \\
\hline Medium- and long-term foreign liabilities & -33 & -26 & -34 & 0 & -33 & 0 \\
\hline Domestic assets & 676 & 984 & 1060 & 864 & 845 & 863 \\
\hline Bank reserves & 515 & 229 & 373 & 132 & 159 & 291 \\
\hline Vault cash & 76 & 37 & 63 & 19 & 57 & 69 \\
\hline Deposits with central bank & 439 & 192 & 310 & 114 & 103 & 222 \\
\hline Deposits with other monetary institutions & 1 & 4 & 1 & 2 & 2 & 1 \\
\hline Domestic credit & 100 & 634 & 639 & 735 & 707 & 528 \\
\hline Claims on central government (treasury) & 87 & 324 & 269 & 385 & 381 & 270 \\
\hline Claims on local government & $\mathbf{0}$ & $\mathbf{0}$ & $\mathbf{0}$ & 0 & o & $\mathbf{0}$ \\
\hline Claims on other government agencies & $\mathbf{0}$ & $\mathbf{0}$ & $\mathbf{0}$ & 0 & 0 & $\mathbf{0}$ \\
\hline Credit to the economy & 13 & 310 & 371 & 350 & 326 & 258 \\
\hline Public enterprises & 0 & 0 & 0 & 0 & 0 & 0 \\
\hline Private enterprises & 13 & 310 & 371 & 350 & 326 & 258 \\
\hline Other items & 59 & 117 & 47 & -5 & -23 & 43 \\
\hline Domestic liabilities & -382 & .684 & -811 & -804 & -670 & -639 \\
\hline Other banks' deposits & 0 & 0 & 0 & 0 & 0 & 0 \\
\hline General government deposits & 0 & 0 & -10 & -9 & -8 & -4 \\
\hline Central govermment (treasury) & 0 & 0 & -10 & -9 & -8 & -4 \\
\hline Foreign-currency deposits & 0 & 0 & $\mathbf{0}$ & 0 & $\mathbf{0}$ & $\mathbf{0}$ \\
\hline Project deposits & $\mathbf{0}$ & 0 & 0 & 0 & 0 & $\mathbf{0}$ \\
\hline Local governments' deposits & 0 & 0 & 0 & o & $\mathbf{0}$ & $\mathbf{0}$ \\
\hline Other government agencies & $\mathbf{0}$ & $\mathbf{0}$ & $\mathbf{0}$ & $\mathbf{0}$ & 0 & 0 \\
\hline INPS $1 /$ & 0 & 0 & 0 & 0 & 0 & 0 \\
\hline Other & 0 & 0 & 0 & 0 & 0 & 0 \\
\hline Demand deposits & -249 & -459 & -514 & -418 & -384 & -409 \\
\hline Nonmonetary financial institutions & 0 & 0 & 0 & 0 & 0 & 0 \\
\hline Nonfinancial public enterprises & 0 & 0 & 0 & 0 & 0 & 0 \\
\hline Private sector & -234 & -448 & -504 & -408 & -368 & -386 \\
\hline Emigrants & -4 & -7 & -10 & -9 & -15 & -22 \\
\hline Other & -11 & -3 & -1 & -1 & -1 & -1 \\
\hline Time deposits & -133 & -194 & -222 & -192 & -189 & -157 \\
\hline Nonmonetary financial institutions & 0 & 0 & 0 & 0 & 0 & 0 \\
\hline Nonfinancial public enterprises & 0 & 0 & 0 & 0 & 0 & 0 \\
\hline Private sector & -129 & -182 & -210 & -174 & -169 & -143 \\
\hline Emigrants & -5 & -12 & -12 & -15 & -7 & -11 \\
\hline Other & $\mathbf{0}$ & $\mathbf{0}$ & $\mathbf{0}$ & -3 & -12 & -4 \\
\hline Foreign exchange deposits (residents) & $\mathbf{0}$ & -32 & -65 & -186 & .90 & .69 \\
\hline Central bank refinancing & o & $\mathbf{0}$ & 0 & 0 & 0 & 0 \\
\hline Capital account & 280 & 290 & 287 & 288 & 291 & 330 \\
\hline Capital & 300 & 300 & 300 & 300 & 300 & 300 \\
\hline Reserves and provisions & 0 & 7 & 4 & 5 & 8 & 9 \\
\hline Gains and losses & -20 & -17 & -17 & -17 & -17 & 21 \\
\hline
\end{tabular}

Source: Banco Totta e Acores.

1/ Instituto Nacional de Previdencia Social (INPS). 
Table 27. Cape Verde: Summary Accounts of the Caixa Geral de Depositos, 1996-98

(In millions of Cape Verde escudos)

\begin{tabular}{|c|c|c|c|c|c|c|}
\hline & \multirow[t]{2}{*}{1996} & \multirow[t]{2}{*}{1997} & \multicolumn{4}{|c|}{1998} \\
\hline & & & Mat. & Jan. & Sep. & Dec. \\
\hline Net foreign assets & $\ldots$ & $\ldots$ & 87 & 36 & 56 & 179 \\
\hline Gross foreign assets & $\ldots$ & $\ldots$ & 91 & 47 & 77 & 206 \\
\hline Short-term foreign liabilities & $\ldots$ & $\ldots$ & -4 & -11 & -21 & -27 \\
\hline Nonresident deposits & $\ldots$ & $\ldots$ & -4 & -11 & -21 & -27 \\
\hline Others & $\ldots$ & $\ldots$ & 0 & $\mathbf{0}$ & $\mathbf{0}$ & 0 \\
\hline Medium- and long-lerm foreign liabilities & $\ldots$ & $\ldots$ & $\mathbf{0}$ & $\mathbf{0}$ & $\mathbf{0}$ & $\mathbf{0}$ \\
\hline Domestic assets & $\ldots$ & $\ldots$ & 397 & 677 & 969 & 1,106 \\
\hline Bank reserves & $\ldots$ & $\ldots$ & 216 & 257 . & 450 & 302 \\
\hline Vault cash & $\ldots$ & $\ldots$ & 17 & 22 & 13 & 86 \\
\hline Deposits with central bank & $\ldots$ & $\ldots$ & 200 & 235 & 437 & 216 \\
\hline Deposits with other monetary institutions & $\ldots$ & $\ldots$ & 0 & 0 & 7 & 41 \\
\hline Domestic credit & $\ldots$ & $\ldots$ & 162 & 425 & 417 & 667 \\
\hline Claims on central government (treasury) & $\ldots$ & $\ldots$ & 150 & 380 & 330 & 525 \\
\hline Claims on local govemment & $\ldots$ & $\ldots$ & 0 & $\mathbf{0}$ & $\mathbf{0}$ & o \\
\hline Claims on other government agencies & $\ldots$ & $\ldots$ & 0 & $\mathbf{0}$ & $\mathbf{0}$ & $\mathbf{0}$ \\
\hline Credit to the economy & $\ldots$ & $\ldots$ & 12 & 45 & 87 & 143 \\
\hline Public enterprises & $\ldots$ & $\ldots$ & 0 & 0 & 0 & 0 \\
\hline Private enterprises & $\ldots$ & $\ldots$ & 12 & 45 & 87 & 143 \\
\hline Other items & $\ldots$ & $\ldots$ & 18 & -5 & 96 & 96 \\
\hline Domestic liabilities & $\ldots$ & $\ldots$ & -184 & -413 & -724 & -983 \\
\hline Other banks' deposits & $\ldots$ & $\ldots$ & 0 & 0 & 0 & 0 \\
\hline General government deposits & $\ldots$ & $\ldots$ & 0 & $\mathbf{0}$ & $\mathbf{0}$ & $\mathbf{0}$ \\
\hline Central government deposits (treasury) & $\ldots$ & $\ldots$ & $\mathbf{0}$ & $\mathbf{0}$ & $\mathbf{0}$ & $\mathbf{0}$ \\
\hline Foreign-currency deposits & $\ldots$ & $\ldots$ & $\mathbf{0}$ & 0 & $\mathbf{0}$ & $\mathbf{0}$ \\
\hline Project deposits & $\ldots$ & $\ldots$ & 0 & 0 & $\mathbf{0}$ & $\mathbf{0}$ \\
\hline Local governments' deposits & $\ldots$ & $\ldots$ & 0 & 0 & $\mathbf{0}$ & 0 \\
\hline Deposits of other government agencies & $\ldots$ & $\ldots$ & 0 & $\mathbf{0}$ & $\mathbf{0}$ & $\mathbf{0}$ \\
\hline MNS 1/ & $\ldots$ & $\ldots$ & $\mathbf{0}$ & $\mathbf{0}$ & $\mathbf{0}$ & $\mathbf{0}$ \\
\hline Other & $\ldots$ & ... & $\mathbf{0}$ & 0 & $\mathbf{0}$ & $\mathbf{0}$ \\
\hline Demand deposits & $\ldots$ & $\ldots$ & -178 & -399 & -648 & -853 \\
\hline Nonmonetary financial institutions & $\ldots$ & $\ldots$ & 0 & 0 & 0 & 0 \\
\hline Nonfinancial public enterprises & $\ldots$ & $\ldots$ & 0 & 0 & 0 & 0 \\
\hline Private sector & $\ldots$ & $\ldots$ & -178 & -395 & -640 & -841 \\
\hline Emigrants & $\ldots$ & $\ldots$ & -1 & -4 & -7 & -10 \\
\hline Other 2/ & $\ldots$ & $\ldots$ & 0 & 0 & 0 & -3 \\
\hline Time deposits & $\ldots$ & $\ldots$ & -5 & -14 & -57 & -69 \\
\hline Nonmonetary financial institutions & $\ldots$ & $\ldots$ & 0 & 0 & $\mathbf{0}$ & $\mathbf{0}$ \\
\hline Nonfinancial public enterprises & $\ldots$ & $\ldots$ & 0 & 0 & 0 & 0 \\
\hline Private sector & $\ldots$ & $\ldots$ & -5 & -14 & -57 & -69 \\
\hline Emigrants & $\ldots$ & $\ldots$ & 0 & 0 & 0 & 0 \\
\hline Other $2 /$ & $\ldots$ & $\ldots$ & 0 & 0 & 0 & 0 \\
\hline Foreign exchange deposits (residents) & $\ldots$ & $\cdots$ & 0 & 0 & -19 & -61 \\
\hline Central bank refinancing & $\ldots$ & $\ldots$ & 0 & 0 & 0 & 0 \\
\hline Capital account & $\ldots$ & $\ldots$ & 300 & 300 & 301 & 302 \\
\hline Capital & $\ldots$ & $\ldots$ & 300 & 300 & 300 & 300 \\
\hline Reserves and provisions & $\cdots$ & $\ldots$ & 0 & 0 & 1 & 2 \\
\hline Gains and losses & $\ldots$ & $\ldots$ & 0 & 0 & 0 & 0 \\
\hline
\end{tabular}

Source: Caixa Geral de Depositos.

1/ Instituto Nacional de Previdencia Social (INPS)

2/ Deposits outside M2. 
Table 28. Cape Verde: Net Claims on Government, 1994-98

(In millions of Cape Verde escudos)

$1994 \quad 1995 \quad 1996$

1997

\begin{tabular}{ccc}
\multicolumn{4}{c}{1998} \\
\hline Mar. Jun. Sep. Dec.
\end{tabular}

Central bank

Claims on general government

Claims on central government

Advances to the treasury

Public enterprise debt

Other claims

Claims on the Trust Fund

Claims on local government

Claims on other government agencies

General government deposits

Central government deposits

Deposits in local currency

Deposits in foreign ourrency

Project deposits

Other government deposits (IDA loan)

Deposits of other government agencies

Use of Fund resources

Net claims on general government

Net claims on central government

\section{ommercial banks}

Claims on general govornment

Claims on central government (treasury)

Claims on the Trust Fund

Claims on local government

Claims on other government agencies

General government deposits

Central government deposits (treasury)

Foreign-currency deposits

Project deposits

Local government deposits

Deposits of other public agencies

Net clains on general government

Net claims on central government

Total banking system

Net claims on general government

Central bank

Commercial banks

Net claims on central government (TOFE)

Central bank

Commercial banks

4,468

4,363

4,363

634

0

3,729

0

0

104

$-294$

$-21$

..

.

$-273$

0

4,17

4,174
4,342

\section{6,103}

6,047

(6)

5

$-2,23$

$-2,23$
-576

$-576$

0
-116

$-352$

$-1,187$

3,873

5,470

7,642

7,545

9,149

8,980

10,268

10,088

10,305

10,125

0

120

60

$-2,179$

$-79$

$-110$

$-303$

$-174$

$-1,514$

8,126

10,047

6,989

6,430

8,193

9,757

13,254

5,128

8,126

15,765

5,719

10,047

4,174

3,873

4,712

5,115

9,813

11,845

13,341

4,342

6,989

5,470
7,957

6,506

0
5758

5,758
747

747
1,357

0

95

$-845$

$-180$

0

$-180$

$-578$

$-182$

95

0
7,11

7,112

6,326

10,404

10,213

10,112

9,921

10,248

10,058

131

60

$-1,933$

$-88$

$-55$

$-196$

$-250$

$-1,344$

8,471

10,125

15,583

16,215

16,037

7,112

7,844

7,945

8,471

8,371

8,093

16,451

16,073

15,222

6,326

6,228

5,246

$10,125 \quad 9,845 \quad 9,975$

Sources: Bank of Cape Verde; and staff estimates. 
Table 29. Cape Verde: Interest Rate Structure, 1994-98

(In percent)

\begin{tabular}{|c|c|c|c|c|c|c|c|c|}
\hline & \multirow[t]{2}{*}{1994} & \multirow[t]{2}{*}{1995} & \multirow[t]{2}{*}{1996} & \multirow[t]{2}{*}{1997} & \multicolumn{4}{|c|}{1998} \\
\hline & & & & & Q1 & Q2 & Q3 & $\overline{Q 4}$ \\
\hline \multicolumn{9}{|l|}{ Lending rates } \\
\hline Up to 90 days & & & $11.5-12.8$ & $11.5-12.8$ & 12.6 & 12.5 & 12.5 & 12.5 \\
\hline From 91 to 180 days & 12.0 & 12.0 & $12.8-14.0$ & $11.5-14.0$ & 12.4 & 12.4 & 12.4 & 12.4 \\
\hline From 181 days to one year & $\ldots$ & $\ldots$ & $12.0 \div 13.0$ & $12.0-13.8$ & 12.8 & 12.8 & 12.8 & 12.8 \\
\hline From one to two years & $\ldots$ & $\ldots$ & $13.8-14.0$ & $13.5-14.0$ & 13.7 & 13.7 & 13.7 & 13.7 \\
\hline From two to five years & $\ldots$ & 13.0 & $13.0-14.0$ & 14.0 & 13.5 & 13.6 & 13.6 & 13.6 \\
\hline More than five years & 13.0 & 13.0 & $13.8-14.0$ & $13.8-14.0$ & 13.6 & 13.6 & 13.6 & 13.6 \\
\hline \multicolumn{9}{|l|}{ Deposit rates } \\
\hline Up to 60 days & $\ldots$ & $\ldots$ & 4.0 & 4.0 & 4.1 & 4.1 & 4.1 & 4.1 \\
\hline From 61 to 180 days & $\ldots$ & $\ldots$ & $4.0-5.0$ & $4.0-5.0$ & 5.3 & 5.3 & 5.3 & 5.3 \\
\hline From 91 to 180 days & 5.5 & 5.5 & $5.5-7.0$ & $6.0-7.0$ & 6.6 & 6.5 & 6.5 & 6.5 \\
\hline From 181 days to one year & 8.5 & 8.5 & $8.0-8.5$ & $7.5-8.5$ & 7.3 & 7.9 & 7.9 & 7.9 \\
\hline More than one year & 9.0 & 9.0 & $8.0-9.0$ & $7.5-9.0$ & 7.8 & 7.8 & 7.8 & 7.8 \\
\hline \multicolumn{9}{|l|}{ Emigrant deposits } \\
\hline Special accounts & 12.0 & 12.0 & $10.0-12.0$ & $9.0-12.0$ & $\ldots$ & $\ldots$ & $\ldots$ & $\ldots$ \\
\hline Up to 90 days & $\ldots$ & $\ldots$ & $\ldots$ & $\ldots$ & 2.4 & 2.4 & 2.4 & 2.4 \\
\hline From 91 to 180 days & $\ldots$ & $\ldots$ & $\ldots$ & $\ldots$ & 7.9 & 7.9 & 7.9 & 7.9 \\
\hline From 181 days to one year & $\ldots$ & $\ldots$ & $\ldots$ & $\ldots$ & 9.3 & 9.1 & 9.1 & 9.1 \\
\hline More than one year & $\cdots$ & $\cdots$ & $\cdots$ & $\cdots$ & 9.5 & 9.5 & 9.5 & 9.5 \\
\hline
\end{tabular}

Sources: Bank of Cape Verde; Banco Commercial do Atlantico; Caixa Economica de Cabo Verde; Banco Totta e Acores; and staff estimates. 
Table 30. Cape Verde: Balance of Payments, 1994-98

(In militions of Cape Verde escudos; unless otherwise indicated)

\begin{tabular}{|c|c|c|c|c|c|}
\hline & 1994 & 1995 & 1996 & 1997 & 1998 \\
\hline Current account $1 /$ & $-3,074$ & $-6,360$ & $-5,243$ & $-6,411$ & $-7,587$ \\
\hline Excluding official current transfers & $-6,342$ & $-7,836$ & $-5,981$ & $-7,907$ & $-8,090$ \\
\hline Trade balance & $-14,017$ & $-16,019$ & $.14,545$ & $-15,930$ & $-17,297$ \\
\hline Exports, f.o.b. & 1,658 & 1,930 & 2,441 & 3,743 & 2,702 \\
\hline Imports, foo.b. & $-15,675$ & $-17,949$ & $-16,986$ & $-19,673$ & $-19,999$ \\
\hline Services (net) & 1,350 & 939 & 1,203 & 2,088 & 1,740 \\
\hline Factor income(net) & -289 & -408 & -557 & -648 & -611 \\
\hline Of which: scheduled interest payments & -301 & -379 & -461 & -459 & -524 \\
\hline technical assistance & -269 & -226 & -245 & -557 & -297 \\
\hline trust fund interest receipts & 0 & 0 & 0 & 0 & 0 \\
\hline Current transfers (net) & 9,882 & 9,129 & 8,656 & 8,079 & 8,581 \\
\hline Official (net) $2 /$ & 3,268 & 1,476 & 738 & 1,496 & 503 \\
\hline Of which: food aid & 1,228 & 1,678 & 1,017 & 1,079 & 1,009 \\
\hline Private & 6,614 & 7,653 & 7,918 & 6,583 & 8,078 \\
\hline Of which: remittances (net) & 6,322 & 7,308 & 7,505 & 6,500 & 7,639 \\
\hline Capital and financial account & 4,204 & 6,782 & 7,864 & 6,696 & 8,212 \\
\hline Direct investment and project grants & 1,839 & 5,893 & 6,728 & 4,745 & 5,325 \\
\hline Direct investment (net) & 196 & 1,968 & 2,334 & 1,074 & 619 \\
\hline Of which : privatization & & 0 & 0 & 0 & 0 \\
\hline Project grants $2 /$ & 1,643 & 3,925 & 4,394 & 3,671 & 4,706 \\
\hline Disbursements & 3,162 & 1,764 & 1,890 & 2,809 & 5,105 \\
\hline Central government & 1,862 & 1,350 & 1,890 & 1,844 & 2,126 \\
\hline Public enterprises & 1,300 & 414 & 0 & 965 & 185 \\
\hline Trust fund & 0 & 0 & 0 & 0 & 2,795 \\
\hline Amortizations due & .797 & -742 & -787 & $-1,232$ & $-1,429$ \\
\hline Central government & -614 & -580 & -523 & -798 & $-1,049$ \\
\hline Public enterprises & -183 & -162 & -264 & -433 & -380 \\
\hline Trust fund investments & 0 & 0 & 0 & 0 & $-2,794$ \\
\hline Private capital flows & 0 & 97 & .3 & 66 & 501 \\
\hline Short term capital & 0 & -230 & 35 & 307 & 1,504 \\
\hline Bridge loan & 0 & 0 & 0 & 0 & 854 \\
\hline Commercial credits & 0 & 0 & 0 & 0 & 650 \\
\hline Others & & -230 & 35 & 307 & 0 \\
\hline Net errors and omissions & $-1,617$ & $-1,477$ & $-1,095$ & 592 & -656 \\
\hline Overall balance & -487 & $-1,055$ & 1,526 & 877 & -32 \\
\hline Finarcing & 487 & 1,055 & $-1,526$ & -877 & 32 \\
\hline Change in net reserves & 239 & 729 & $-1,826$ & 968 & -33 \\
\hline Central bank & 1,496 & $-1,075$ & 128 & 286 & 776 \\
\hline Commercial banks & $-1,258$ & 1,803 & $-1,954$ & 682 & .810 \\
\hline Change in arrears & & 326 & 300 & $-1,846$ & 65 \\
\hline Exceptional financing & 248 & 0 & 0 & 0 & 0 \\
\hline Rescheduling and cancellation of debt & 248 & 0 & 0 & 0 & 0 \\
\hline \multicolumn{6}{|l|}{ Memorandum items: } \\
\hline Central bank's ret reserves & 3,434 & 5,108 & 4,540 & 4,331 & 3,496 \\
\hline In months of imports of goods and services & 2.3 & 2.7 & 2.4 & 2.0 & 1.5 \\
\hline Export of goods and services & 5,637 & 7,218 & 9,211 & 12,286 & 12,139 \\
\hline In percent of GDP & 16.8 & 19.1 & 22.7 & 27.2 & 24.9 \\
\hline Imports of goods and services & $-18,304$ & $-22,298$ & $-22,554$ & $-26,128$ & $-27,696$ \\
\hline In percent of GDP & 54.4 & 58.9 & 55.5 & 57.9 & 56.9 \\
\hline Current account, incl. official transfers (percent of GDP) & -9.1 & -16.8 & -12.9 & -14.2 & -15.6 \\
\hline Current account, excl. official transfers (percent of GDP) & -18.9 & -20.7 & -14.7 & -17.5 & -16.6 \\
\hline Cape Verde escudos per U.S. dollar (period average) & 81.89 & 76.85 & 82.59 & 93.18 & 98.20 \\
\hline Nominal GDP & 33,641 & 37,864 & 40,638 & 45,101 & 48,667 \\
\hline
\end{tabular}

Sources: Bank of Cape Verde; and staff estimates.

1/ In 1997, the Cape Verdean authorities began to record sales of fuel to ships in full; previousily they had been recorded only partially. The staff has attempted to replicate this new, more accurate presentation for the years 1997-98. The staff has also moved the item to "Exports", rather than "Services," to comply with the stipulations of the Balence of Payments Manual (Sth edition).

$2 /$ This series differs from that presented in previous staff reports, because it conforms with the Balance of Payments Mamual (5th edition), concerning the difference between eurrent and capital transfers. 
Table 31. Cape Verde: Balance of Payments, 1994-98

(In millions of U.S. dollars; unless otherwise indicated)

\begin{tabular}{|c|c|c|c|c|c|}
\hline & 1994 & 1995 & 1996 & 1997 & 1998 \\
\hline Current account $1 /$ & -37.5 & -82.8 & -63.5 & -68.8 & -77.3 \\
\hline Excluding official current transfers & -77.4 & -102.0 & -72.4 & -84.9 & -82.4 \\
\hline Trade balance & -171.2 & -208.4 & -176.1 & -171.0 & -176.1 \\
\hline Exports, f.o.b. & 20.2 & 25.1 & 29.6 & 40.2 & 27.5 \\
\hline Imports, f.o.b. & -191.4 & -233.6 & -205.7 & -211.1 & -203.7 \\
\hline Services (net) & 16.5 & 12.2 & 14.6 & 22.4 & 17.7 \\
\hline Factor income(net) & -3.5 & -5.3 & -6.7 & -7.0 & -6.2 \\
\hline Of which: scheduled interest payments & -3.7 & -4.9 & -5.6 & -4.9 & -5.3 \\
\hline technical assistance & -3.3 & -2.9 & -3.0 & -6.0 & -3.0 \\
\hline trust fund interest receipts & 0.0 & 0.0 & 0.0 & 0.0 & 0.0 \\
\hline Current transfers (net) & 120.7 & 118.8 & 104.8 & 86.7 & 87.4 \\
\hline Official (net) 2 & 39.9 & 19.2 & 8.9 & 16.1 & 5.1 \\
\hline Of which: food aid & 15.0 & 21.8 & 12.3 & 11.6 & 10.3 \\
\hline Private & 80.8 & 99.6 & 95.9 & 70.7 & 82.3 \\
\hline Of which: remittances (net) & 77.2 & 95.1 & 90.9 & 69.8 & 77.8 \\
\hline Capital and financial account & $\$ 1.3$ & 88.2 & 95.2 & 71.9 & 83.6 \\
\hline Direct investment and project grants & 22.5 & $\mathbf{7 6 . 7}$ & 81.5 & 50.9 & 54.2 \\
\hline Direct investment (net) & 2.4 & 25.6 & 28.3 & 11.5 & 6.3 \\
\hline Of which : privatization & 0.0 & 0.0 & 0.0 & 0.0 & 0.0 \\
\hline Project grants 2 & 20.1 & 51.1 & 53.2 & 39.4 & 47.9 \\
\hline Disbursements & 38.6 & 23.0 & 22.9 & 30.2 & 52.0 \\
\hline Central government & 22.7 & 17.6 & 22.9 & 19.8 & 21.7 \\
\hline Public enterprises & 15.9 & 5.4 & 0.0 & 10.4 & 1.9 \\
\hline Trust fund & 0.0 & 0.0 & 0.0 & 0.0 & 28.5 \\
\hline Amortizations due & -9.7 & -9.6 & -9.5 & -13.2 & -14.6 \\
\hline Central government & -7.5 & -7.5 & -6.3 & -8.6 & -10.7 \\
\hline Public enterprises & -2.2 & -2.1 & -3.2 & -4.6 & -3.9 \\
\hline Trust fund investments & 0.0 & 0.0 & 0.0 & 0.0 & -28.5 \\
\hline Private capital flows & 0.0 & 1.3 & 0.0 & 0.7 & 5.1 \\
\hline Short term capital & 0.0 & -3.0 & 0.4 & 3.3 & 15.3 \\
\hline Bridge loan & 0.0 & 0.0 & 0.0 & 0.0 & 8.7 \\
\hline Commercial credits & 0.0 & 0.0 & 0.0 & 0.0 & 6.6 \\
\hline Others & 0.0 & -3.0 & 0.4 & 3.3 & 0.0 \\
\hline Net errors and omissions & -19.7 & -19.2 & -13.3 & 6.4 & -6.7 \\
\hline Overall balance & -5.9 & -13.7 & 18.5 & 9.4 & -0.3 \\
\hline Financing & 5.9 & 13.7 & -18.5 & -9.4 & 0.3 \\
\hline Change in net reserves & 2.9 & 9.5 & -22.1 & 10.4 & -0.3 \\
\hline Central bank & 18.3 & -14.0 & 1.5 & 3.1 & 7.9 \\
\hline Commercial banks & -15.4 & 23.5 & -23.7 & 7.3 & -8.2 \\
\hline Change in arrears & 0.0 & 4.2 & 3.6 & -19.8 & 0.7 \\
\hline Exceptional financing & 3.0 & 0.0 & 0.0 & 0.0 & 0.0 \\
\hline Rescheduling and cancellation of debt & 3.0 & 0.0 & 0.0 & 0.0 & 0.0 \\
\hline \multicolumn{6}{|l|}{ Memorandum items: } \\
\hline Central bank's net reserves & 41.9 & 66.5 & 55.0 & 46.5 & 35.6 \\
\hline Exports of goods and services & 68.8 & 93.9 & 111.5 & 131.9 & 123.6 \\
\hline Imports of goods and services & -223.5 & -290.1 & -273.1 & -280.4 & -282.0 \\
\hline Nominal GDP & 410.8 & 492.7 & 492.0 & 484.0 & 495.6 \\
\hline
\end{tabular}

Sources: Bank of Cape Verde; and staff estimates.

1/ In 1997, the Cape Verdean authorities began to record sales of fuel to ships in full; previously they had been recorded only partially. The staff has attempted to replicate this new, more accurate presentation for the years 1997-98. The staff has also moved the item to "Exports", rather than "Services," to comply with the stipuiations of the Balance of Payments Mamual (5th edition).

2/ This series differs from that presented in previous staff reports, because it conforms with the Balance of Payments Manual (5th edition), concerming the difference between current and capital transfers. 
Table 32. Cape Verde: Merchandise Exports, 1994-2000

(In millions of Cape Verde escudos)

\begin{tabular}{|c|c|c|c|c|c|}
\hline & 1994 & 1995 & 1996 & 1997 & 1998 \\
\hline Agricultural products & 4 & 3 & 0 & 0 & 1 \\
\hline Of which: bananas & 4 & 3 & 0 & 0 & 1 \\
\hline Fish and crustaceans & 196 & 163 & 171 & 262 & 181 \\
\hline Fish and tuna & 67 & 66 & 118 & 228 & 105 \\
\hline Canned & 6 & 4 & 1 & 77 & 0 \\
\hline Frozen & 61 & 40 & 98 & 79 & 99 \\
\hline Fresh & 1 & 22 & 19 & 72 & 5 \\
\hline Shellfish and lobster & 129 & 97 & 53 & 34 & 76 \\
\hline Shoes and shoe parts & 190 & 416 & 586 & 813 & 609 \\
\hline Clothing & 0 & 0 & 188 & 155 & 193 \\
\hline Skins and hides & 3 & 5 & 3 & 5 & 6 \\
\hline Other & 4 & 59 & 91 & 59 & 34 \\
\hline Total exports (except fuel) & 398 & 646 & 1,039 & 1,294 & 1,024 \\
\hline Goods procured in ports by carriers (fuel) & 1,260 & 1,283 & 1,402 & 2,449 & 1,678 \\
\hline Total exports & 1,658 & 1,930 & 2,441 & 3,743 & 2,702 \\
\hline
\end{tabular}

Sources: Bank of Cape Verde; and staff estimates 
Table 33. Cape Verde: Imports, 1994-98

(In millions of Cape Verde escudos; unless otherwise indicated)

\begin{tabular}{|c|c|c|c|c|c|}
\hline & 1994 & 1995 & 1996 & 1997 & 1998 \\
\hline Life animals and animal products & & & 838 & 889 & 1,025 \\
\hline Of which: $m$ ilk & & & 607 & 495 & 616 \\
\hline Butter & & & 17 & 17 & 17 \\
\hline Vegetable products & & & 1,801 & 3,042 & 2,472 \\
\hline Of which: beans & & & 123 & 209 & 350 \\
\hline Maize & & & 161 & 1,027 & 599 \\
\hline Potatoes & & & 88 & 124 & 152 \\
\hline Rice & & & 616 & 834 & 625 \\
\hline Wheat grain & & & 207 & 256 & 220 \\
\hline Edible oils and fats & & & 926 & 805 & 1,079 \\
\hline Of which: lard & & & 98 & 51 & 82 \\
\hline Olive oil & & & 15 & 167 & 82 \\
\hline Food and beverage products & & & 2,662 & 2,571 & 3,222 \\
\hline Ofwhich: sugar & & & 631 & 564 & 665 \\
\hline Beer & & & 54 & 94 & 330 \\
\hline Wines & & & 275 & 209 & 222 \\
\hline Mineral products & & & 2,305 & 2,111 & 1,949 \\
\hline Of which: cement & & & 847 & 923 & 815 \\
\hline Fuel oil & & & 107 & 116 & 58 \\
\hline Diesel oil & & & 521 & 555 & 483 \\
\hline Gasoline & & & 99 & 115 & 101 \\
\hline Lamp oil & & & 42 & 24 & 35 \\
\hline Chemical products & & & 978 & 1,136 & 1,375 \\
\hline Of which: a ntibiotics & & & 37 & 4 & 10 \\
\hline Matches & & & 15 & 0 & 20 \\
\hline Other pharmaceuticals & & & 274 & 0 & 295 \\
\hline Plastics and rubber & & & 727 & 766 & 798 \\
\hline Hides, skins, and leather & & & 37 & 26 & 25 \\
\hline Wood products & & & 519 & 524 & 518 \\
\hline Paper and paper products & & & 389 & 464 & 558 \\
\hline Textiles & & & 429 & 467 & 560 \\
\hline Shoes & & & 137 & 127 & 175 \\
\hline Stone and glass products & & & 508 & 592 & 721 \\
\hline Metal and metal products & & & 1,558 & 1,324 & 1,632 \\
\hline Machines and electrical equipment & & & 3,199 & 3,627 & 3,887 \\
\hline Transportation material & & & 1,601 & 2,655 & 1,510 \\
\hline Other imports & 320 & & 721 & 812 & 887 \\
\hline Merchandise imports, c.i.f. & 17,108 & 19,394 & 19,335 & 21,936 & 22,395 \\
\hline Foodstuff imports & 5,291 & 6,510 & 6,227 & 7,307 & 7,798 \\
\hline Petroleum imports & 401 & 831 & 769 & 809 & 676 \\
\hline Other imports & 11,416 & 12,053 & 12,339 & 13,820 & 13,920 \\
\hline Total merchandise imports, f.o.b. & $-15,675$ & $-17,949$ & $-16,986$ & $-19,673$ & $-19,999$ \\
\hline Ratio of imports, c.i.f., to imports, f.o.b. 1/ & 109 & 108 & 114 & 112 & 112 \\
\hline
\end{tabular}

Sources: Bank of Cape Verde; and staff estimates.

$1 /$ In percent 
Table 34. Cape Verde: Services, 1994-98

(In millions of Cape Verde escudos)

\begin{tabular}{|c|c|c|c|c|c|}
\hline & 1994 & 1995 & 1996 & 1997 & 1998 \\
\hline Total services (net) & 1,350 & 939 & 1,203 & 2,088 & 1,740 \\
\hline Credit & 3,979 & 5,288 & 6,771 & 8,543 & 9,437 \\
\hline Freight & 2 & 0 & 0 & 29 & 38 \\
\hline Other transport & 1,986 & 2,800 & 4,091 & 5,240 & 4,952 \\
\hline Passenger services & 935 & 1,440 & 2,150 & 3,301 & 2,872 \\
\hline Other supplies & 0 & 13 & 1 & 0 & 0 \\
\hline Port and airport services & 716 & 1,021 & 1,103 & 1,624 & 1,449 \\
\hline Ship and plane repairs & 163 & 161 & 408 & 285 & 439 \\
\hline Ship chartering & 117 & 109 & 169 & 1 & 151 \\
\hline Other & 54 & 55 & 260 & 29 & 41 \\
\hline Travel & 718 & 744 & 927 & 1,399 & 2,174 \\
\hline Embassies and other official & 625 & 725 & 998 & 1,188 & 1,173 \\
\hline Construction & 6 & 177 & 154 & 243 & 122 \\
\hline Communications & 581 & 757 & 398 & 317 & 465 \\
\hline Other & 63 & 86 & 202 & 128 & 514 \\
\hline Debit & $-2,629$ & $-4,349$ & $-5,568$ & $-6,455$ & $-7,697$ \\
\hline Freight & -346 & -778 & $-1,046$ & $-1,446$ & $-1,580$ \\
\hline Insurance & 0 & 0 & 0 & 0 & 0 \\
\hline Other transport & -652 & $-1,166$ & $-2,178$ & $-2,392$ & $-2,811$ \\
\hline Passenger services & -231 &.-274 & -516 & -699 & -814 \\
\hline Fuel supplies & -3 & -1 & -1 & -231 & -110 \\
\hline Other supplies & -3 & -4 & -6 & 0 & 0 \\
\hline Port and airport services & -45 & -371 & -777 & -288 & -442 \\
\hline Ship and plane repairs & -9 & -1 & -146 & -139 & -14 \\
\hline Ship chartering & -356 & -335 & -526 & -552 & -936 \\
\hline Other & -4 & -180 & -206 & -484 & -495 \\
\hline Travel & -744 & -945 & $-1,102$ & $-1,000$ & $-1,773$ \\
\hline Embassies and other official & -390 & -459 & -646 & -593 & -491 \\
\hline Construction & -12 & -18 & -19 & -65 & -89 \\
\hline Communications & -141 & -301 & -41 & -37 & -17 \\
\hline Other & -345 & -683 & -535 & -922 & $-9,36$ \\
\hline \multicolumn{6}{|l|}{ Memorandum item: } \\
\hline Fuel supplies & 1,146 & 1,260 & 1,283 & 2,449 & 1,678 \\
\hline
\end{tabular}

Sources: Bank of Cape Verde; and staff estimates. 
Table 35. Cape Verde: Direction of Trade, 1994-1998

(In percent of total)

\begin{tabular}{|c|c|c|c|c|c|}
\hline & 1994 & 1995 & 1996 & 1997 & $\begin{array}{c}1998 \\
\text { Jan.-Jun. }\end{array}$ \\
\hline Exports & 100.0 & 100.0 & 100.0 & 100.0 & 100.0 \\
\hline Algeria & 0.0 & 0.0 & 0.0 & 0.0 & 0.0 \\
\hline Angola & 0.0 & 0.0 & 0.0 & 0.0 & 0.0 \\
\hline France & 0.0 & 2.1 & 1.9 & 1.6 & 0.3 \\
\hline Guinea-Bissau & 0.1 & 0.3 & 0.0 & 0.2 & 0.0 \\
\hline Netherlands & 2.1 & 0.9 & 0.5 & 1.0 & 0.3 \\
\hline Portugal & 58.8 & 82.9 & 77.9 & 74.1 & 89.3 \\
\hline Säo Tomé and Príncipe & 0.0 & 0.0 & 0.1 & 0.0 & 0.0 \\
\hline Spain & 0.0 & 7.2 & 11.1 & 8.7 & 7.9 \\
\hline Others & 39.0 & 7.5 & 9.0 & 14.4 & 2.2 \\
\hline Imports & 100.0 & 100.0 & 100.0 & 100.0 & 100.0 \\
\hline Brazil & 3.4 & 4.3 & 3.1 & 0.0 & 0.0 \\
\hline Belgium & 3.1 & 8.4 & 3.2 & 0.0 & 0.0 \\
\hline Côte d'Ivoire & 1.1 & 1.3 & 1.1 & 0.0 & 0.0 \\
\hline Denmark & 3.9 & 1.1 & 0.8 & 0.0 & 0.0 \\
\hline France & 13.8 & 4.0 & 5.6 & 9.2 & 3.7 \\
\hline Germany & 4.0 & 4.1 & 3.1 & 2.1 & 1.6 \\
\hline Italy & 1.1 & 4.0 & 2.8 & 0.0 & 0.0 \\
\hline Japan & 5.0 & 1.4 & 5.5 & 0.0 & 0.0 \\
\hline Netherlands & 8.0 & 7.9 & 7.6 & 11.0 & 11.8 \\
\hline Portugal & 34.5 & 39.8 & 40.9 & 42.8 & 49.9 \\
\hline Romania & 0.6 & 1.3 & 2.1 & 0.0 & 0.0 \\
\hline Spain & 0.9 & 1.7 & 3.8 & 2.4 & 2.7 \\
\hline Sweden & 4.2 & 2.3 & 1.7 & 1.1 & 1.0 \\
\hline United Kingdom & 1.4 & 2.1 & 2.8 & 2.0 & 1.5 \\
\hline United States & 2.3 & 3.3 & 3.6 & 9.4 & 3.1 \\
\hline Others & 12.7 & 13.0 & 12.3 & 20.0 & 24.7 \\
\hline
\end{tabular}

Sources: National Institute of Statistics, Boletin Trimestral de Commercio Externo; and staff estimates. 
Table 36. Cape Verde: Factor Income, 1994-98

(In millions of Cape Verde escudos)

\begin{tabular}{lrrrrr}
\hline & 1994 & 1995 & 1996 & 1997 & 1998 \\
& & & & & \\
& & & & & \\
T'otal factor income (net) & -289 & -408 & -561 & -648 & -611 \\
& & & & & \\
Credit & 346 & 290 & 268 & 704 & 592 \\
Investment income & 119 & 116 & 93 & 251 & 167 \\
Compensation of employees & 193 & 147 & 133 & 203 & 176 \\
Other & 34 & 27 & 41 & 250 & 249 \\
Ofwhich: Technical assistance & 26 & 25 & 41 & 211 & 249 \\
& & & & & \\
Debit & -635 & -699 & -829 & $-1,353$ & $-1,203$ \\
Investment income & -327 & -404 & -531 & -634 & -816 \\
Scheduled interest & -301 & -379 & -461 & -459 & -524 \\
$\quad$ Government & -273 & -270 & -260 & -324 & -359 \\
$\quad$ Public enterprises & -29 & -109 & -201 & -135 & -165 \\
Other investment income & -26 & -24 & -71 & -175 & -292 \\
Compensation of employees & -34 & -62 & -51 & -154 & -53 \\
Other & -273 & -233 & -247 & -564 & -334 \\
Of which: $t$ echnical assistance & -269 & -226 & -245 & -557 & -297 \\
\hline
\end{tabular}

Source: Data provided by the Bank of Cape Verde 
Table 37. Cape Verde: Private and Public Transfers, 1994-98

(In millions of Cape Verde escudos)

\begin{tabular}{|c|c|c|c|c|c|}
\hline & 1994 & 1995 & 1996 & 1997 & 1998 \\
\hline Total transfers (net) & 11,526 & 13,054 & 13,050 & 11,750 & 13,864 \\
\hline Private (net) & 6,614 & 7,653 & 7,918 & 6,583 & 8,120 \\
\hline Credit & 6,805 & 7,989 & 8,155 & 6,917 & 8,442 \\
\hline Remittances & 6,285 & 7,369 & 7,554 & 6,539 & 7,660 \\
\hline Foreign exchange & 5,024 & 5,846 & 6,126 & 5,620 & 7,161 \\
\hline Goods & 1,260 & 1,522 & 1,428 & 919 & 458 \\
\hline Other & 521 & 620 & 601 & 379 & 782 \\
\hline Debit & -191 & -335 & -237 & -334 & -323 \\
\hline Remittances & -38 & -61 & -49 & -39 & -21 \\
\hline Foreign exchange & -38 & -61 & -49 & -39 & -21 \\
\hline Goods & 0 & 0 & 0 & 0 & 0 \\
\hline Other & -153 & -275 & -188 & -295 & -302 \\
\hline Official (net) & 4,911 & 5,401 & 5,132 & 5,167 & 5,744 \\
\hline Official (current) & 1,228 & 1,476 & 738 & 1,496 & 503 \\
\hline Credit & 1,446 & 1,775 & 1,105 & 2,103 & 1,200 \\
\hline Of which: Food aid & 1,228 & 1,678 & 1,017 & 1,079 & 1,009 \\
\hline Debit & -217 & -299 & -367 & -607 & -697 \\
\hline Official (capital) & 3,683 & 3,925 & 4,394 & 3,671 & 5,241 \\
\hline
\end{tabular}

Source: Cape Verdean authorities and staff estimates

1/ Includes unclassified food and equipment aid 
Table 38. Cape Verde: Food Aid, 1994-98

(Value in thousands of U.S. dollars; volumes in metric tons; unit values in U.S. dollars)

\begin{tabular}{|c|c|c|c|c|c|}
\hline & 1994 & 1995 & 1996 & 1997 & 1998 \\
\hline Maize & 6,134 & 6,458 & 1,754 & 3,873 & 2,717 \\
\hline Volume & 39,644 & 40,972 & 4,928 & 25,213 & 19,435 \\
\hline Unit value & 155 & 158 & 356 & 154 & 140 \\
\hline Wheat & 1,807 & 1,265 & 215 & 1,545 & 1,450 \\
\hline Volume & 16,440 & 10,802 & 1,970 & 15,991 & 15,831 \\
\hline Unit value & 110 & 117 & 109 & 97 & 92 \\
\hline Rice & 2,006 & 2,853 & 4,962 & 3,149 & 3,484 \\
\hline Volume & 7,493 & 8,628 & 21,479 & 14,266 & 10,841 \\
\hline Unit value & 268 & 331 & 231 & 221 & 321 \\
\hline Milk Powder $2 /$ & 73 & 262 & 74 & 858 & 434 \\
\hline Volume & 31 & 710 & 383 & 450 & 222 \\
\hline Unit value & 2,344 & 369 & 193 & 1,906 & 1,955 \\
\hline Edible Oils 3/ & 1,389 & 2,013 & 781 & 0 & 410 \\
\hline Volume & 1,200 & 2,062 & 1,023 & 0 & 537 \\
\hline Unit value & 1,157 & 976 & 763 & 0 & 764 \\
\hline Beans 4/ & 0 & 0 & 0 & 1,085 & 896 \\
\hline Volume & 0 & 0 & 0 & 1,463 & 1,203 \\
\hline Unit value & 0 & 0 & 0 & 742 & 744 \\
\hline Others 4/ & 3,592 & 8,980 & 10,838 & 1,158 & 887 \\
\hline Total value & 15,001 & 21,831 & 18,624 & 11,667 & 10,278 \\
\hline
\end{tabular}

Source: Cape Verdean authorities.

$1 /$ Volumes in metric tons, unit values in U.S. dollar per metric ton.

2/ In 1993, the grant from the Netherlands was given in cash.

$3 /$ In liters.

4/ Until 1990, value "Others" included beans. 
Table 39. Cape Verde: External Public Debt, 1994-98 (In millions of Cape Verde escudos)

\begin{tabular}{|c|c|c|c|c|c|}
\hline & 1994 & 1995 & 1996 & 1997 & 1998 \\
\hline Total outstanding external debt (e.o.p.) & $13,411.3$ & $14,664.9$ & $16,667.0$ & $20,110.3$ & $22,481.8$ \\
\hline Of which: arrears & $1,232.2$ & $1,459.4$ & $1,922.5$ & 888.5 & 851.6 \\
\hline On principal & 923.0 & $1,129.2$ & $1,399.4$ & 598.0 & 686.3 \\
\hline On interest & 309.2 & 330.2 & 523.1 & 290.5 & 165.3 \\
\hline By debtor & $13,411.3$ & $14,664.9$ & $16,667.0$ & $20,110.3$ & $22,481.8$ \\
\hline Central government & $9,882.1$ & $11,458.8$ & $13,348.8$ & $15,192.8$ & $17,581.5$ \\
\hline Public enterprises & $3,529.2$ & $3,206.1$ & $3,318.2$ & $4,917.5$ & $4,900.3$ \\
\hline By creditor (official) & $13,411.3$ & $14,664.9$ & $16,667.0$ & $20,110.3$ & $22,481.8$ \\
\hline Multilateral & $10,123.7$ & $11,423.8$ & $12,867.8$ & $15,763.6$ & $17,589.1$ \\
\hline Bilateral & $3,287.6$ & $3,241.1$ & $3,799.2$ & $4,346.7$ & $4,892.7$ \\
\hline Government & 728.1 & 844.6 & $1,577.5$ & $1,908.3$ & $2,673.9$ \\
\hline Export credit agencies & $2,559.5$ & $2,396.5$ & $2,221.7$ & $2,438.4$ & $2,218.8$ \\
\hline Disbursements & $3,162.1$ & $1,764.2$ & $1,890.0$ & $2,809.4$ & $5,105.5$ \\
\hline Central government & $1,862.1$ & $1,350.0$ & $1,890.0$ & $1,844.4$ & $2,126.0$ \\
\hline Public enterprises & $1,300.0$ & 414.2 & 0.0 & 964.9 & 184.9 \\
\hline Trust fund & 0.0 & 0.0 & 0.0 & 0.0 & $2,794.5$ \\
\hline Scheduled debt service payments & $1,098.2$ & $1,121.0$ & $1,047.0$ & $1,586.4$ & $-1,953.2$ \\
\hline Amortization & 796.8 & 741.6 & 787.0 & $1,315.4$ & $-1,429.0$ \\
\hline Central government & 614.2 & 580.0 & 523.0 & 882.2 & $-1,048.8$ \\
\hline Public enterprises & 182.6 & 161.6 & 264.0 & 433.2 & -380.2 \\
\hline Interest & 301.4 & 379.4 & 260.0 & 271.0 & -524.2 \\
\hline Central government & 272.9 & 270.0 & 260.0 & 271.0 & -359.2 \\
\hline Public enterprises & 28.5 & 109.4 & 0.0 & 0.0 & -165.0 \\
\hline Actual debt service payments & 965.9 & 962.9 & 408.3 & $1,280.0$ & $1,314.8$ \\
\hline Amortization & 778.6 & 741.6 & 243.3 & 851.9 & 965.1 \\
\hline Central government & 614.5 & 580.0 & 243.3 & 851.9 & 965.1 \\
\hline Public enterprises & 164.1 & 161.6 & 0.0 & 0.0 & 0.0 \\
\hline Interest & 187.3 & 221.3 & 165.0 & 428.1 & 349.7 \\
\hline Central government & 174.8 & 196.5 & 165.0 & 428.1 & 349.7 \\
\hline Public enterprises & 12.5 & 24.8 & 0.0 & 0.0 & 0.0 \\
\hline Change in arrears (+ increase) & 281.2 & 570.5 & 374.8 & $-1,776.4$ & 64.9 \\
\hline On principal & 172.8 & 416.0 & 279.7 & $-1,230.9$ & 64.5 \\
\hline On interest & 108.4 & 154.5 & 95.1 & -545.5 & 0.4 \\
\hline Payment of old arrears & -158.8 & -20.7 & 0.0 & -185.6 & -3.0 \\
\hline On principal & -153.0 & -17.2 & 0.0 & -76.3 & -3.0 \\
\hline On interest & -5.8 & -3.5 & 0.0 & -109.3 & 0.0 \\
\hline Accumulation of new arrears & 440.0 & 591.2 & 374.8 & -126.8 & 93.2 \\
\hline On principal & 325.8 & 433.2 & 279.7 & 30.3 & 83.7 \\
\hline On interest & 114.2 & 158.0 & 95.1 & -157.1 & 9.5 \\
\hline Rescheduling of arrears & 0.0 & 0.0 & 0.0 & $-1,464.0$ & -25.3 \\
\hline On principal & $\ldots$ & $\ldots$ & 0.0 & $-1,184.9$ & -19.2 \\
\hline On interest & $\ldots$ & $\ldots$ & 0.0 & -279.1 & -6.1 \\
\hline Refinancing of arrears & 0.0 & 0.0 & 0.0 & 0.0 & 0.0 \\
\hline On principal & $\ldots$ & $\ldots$ & 0.0 & 0.0 & 0.0 \\
\hline On interest & $\ldots$ & $\ldots$ & 0.0 & 0.0 & 0.0 \\
\hline
\end{tabular}

Sources: Cape Verdean authorities; and staff estimates. 
Table 40. Cape Verde: External Public Debt by Creditor, 1994-98 (In millions of U.S. dollars; end of period)

\begin{tabular}{|c|c|c|c|c|c|c|c|c|c|c|c|c|c|c|c|}
\hline & \multicolumn{3}{|c|}{1994} & \multicolumn{3}{|c|}{1995} & \multicolumn{3}{|c|}{1996} & \multicolumn{3}{|c|}{1997} & \multicolumn{3}{|c|}{1998} \\
\hline & Contracted & Disbursed & Outstanding & Contracted & Disbursed & Outstanding & Contracted & Disbursed & Outstanding & Contracted & Disbursed & Outstanding & Contracted & Disbursed & Ousstanding \\
\hline Multilateral & 302.8 & 161.7 & 123.6 & 326.9 & 181.1 & 149.3 & 313.5 & 190.9 & 155.8 & 323.1 & 208.8 & 169.2 & 364.3 & 238.1 & 185.3 \\
\hline AfDF $1 /$ & 117.4 & 58.0 & 49.1 & 124.6 & 63.3 & 63.0 & 105.0 & 66.2 & 64.7 & 115.6 & 68.5 & 67.1 & 115.6 & 70 & 67.4 \\
\hline IDA $1 /$ & 48.6 & 26.5 & 26.8 & 61.4 & 32.5 & 32.2 & 73.0 & 41.1 & 40.8 & 73.0 & 50.0 & 49.5 & 110.15 & 73.2 & 67.7 \\
\hline BADEA $1 /$ & 48.0 & 22.5 & 15.0 & 48.0. & 22.5 & 15.5 & 48.0 & 22.5 & 15.5 & 48.0 & 24.4 & 15.3 & 48 & 26.8 & 16.6 \\
\hline AfDB 1/ & 28.4 & 19.4 & 9.0 & 27.8 & 19.6 & 7.8 & 17.1 & 17.1 & 6.0 & 17.1 & 17.1 & 4.9 & 17.1 & 17.1 & 3.4 \\
\hline EIB 1/ & 18.0 & 11.4 & 8.7 & 22.4 & 17.2 & 14.3 & 16.9 & 13.2 & 10.3 & 16.9 & 14.3 & 11.1 & 16.9 & 14.3 & 11.7 \\
\hline OPEC $1 /$ & 20.0 & 12.1 & 4.3 & 20.1 & 12.6 & 4.0 & 20.1 & 14.1 & 4.6 & 20.1 & 17.1 & 7.2 & 24.1 & 18 & 7.4 \\
\hline IFAD $1 /$ & 16.2 & 8.6 & 8.2 & 16.5 & 10.3 & 9.9 & 16.4 & 10.7 & 10.3 & 16.4 & 10.4 & 10.0 & 16.4 & 10.9 & 6.5 \\
\hline Saudi Fund & 3.3 & 3.3 & 2.6 & 3.3 & 3.2 & 2.6 & 3.3 & 3.3 & 2.6 & 2.3 & 2.3 & 1.4 & 2.3 & 2.3 & 1.1 \\
\hline NDF $1 /$ & 2.9 & 0.0 & 0.0 & 2.9 & 0.0 & 0.0 & 2.9 & 0.4 & 0.4 & 2.9 & 0.7 & 0.7 & 2.9 & 1.3 & 1.2 \\
\hline NSF $1 /$ & 0.0 & 0.0 & 0.0 & 0.0 & 0.0 & 0.0 & 10.8 & 2.3 & 0.6 & 10.8 & 3.9 & 2.1 & 10.8 & 4.2 & 2.3 \\
\hline Bilateral & 69.7 & 37.7 & 27.3 & 70.4 & 45.7 & 32.4 & 91.3 & 62.0 & 46.0 & 91.5 & 64.6 & 46.7 & 105.7 & 81.0 & 51.6 \\
\hline Government & 35.4 & 14.6 & 9.1 & 36.1 & 17.8 & 10.7 & 57.0 & 29.0 & 19.1 & 57.2 & 31.2 & 20.5 & 71.4 & 47.6 & 28.2 \\
\hline China & 9.4 & 5.9 & 5.9 & 9.4 & 5.9 & 5.9 & 21.3 & 13.4 & 13.4 & 21.3 & 13.4 & 13.4 & 21.3 & 13.4 & 5.1 \\
\hline Kuwait & 13.0 & 3.4 & 2.0 & 13.0 & 4.3 & 2.5 & 19.8 & 5.8 & 3.8 & 20.1 & 8.1 & 5.2 & 20.1 & 8.6 & 4.9 \\
\hline Portugal & 7.5 & 0.6 & 0.6 & 7.5 & 1.7 & 1.7 & 7.5 & 1.7 & 1.7 & 7.5 & 1.7 & 1.7 & 21.6 & 17.5 & 18 \\
\hline South Africa & 4.0 & 4.5 & 0.4 & 5.1 & 5.8 & 0.5 & 6.9 & 7.9 & 0.0 & 6.9 & 7.9 & 0.0 & 6.9 & 7.9 & 0 \\
\hline Abu Dhabi & 1.5 & 0.2 & 0.2 & 1.1 & 0.1 & 0.1 & 1.5 & 0.2 & 0.2 & 1.5 & 0.2 & 0.2 & 1.5 & 0.2 & 0.2 \\
\hline Germany & & & & & & & & & & & & & 12.7 & & \\
\hline Export credit agencies & 34.3 & 23.1 & 18.2 & 34.3 & 27.9 & 21.8 & 34.3 & 33.0 & 26.9 & 34.3 . & 33.4 & 26.2 & 34.3 & 33.4 & 23.4 \\
\hline Caisse Général des Dépôts & 12.0 & 11.6 & 7.5 & 12.0 & 11.6 & 6.3 & 12.0 & 11.6 & 6.3 & 12.0 & 11.6 & 6.3 & 12 & 11.6 & 5.5 \\
\hline ICO (Spain) & 7.3 & 6.7 & 6.7 & 7.3 & 6.7 & 6.7 & 7.3 & 6.8 & 6.8 & 7.3 & 6.8 & 6.8 & 7.3 & 6.8 & 6.9 \\
\hline CACEX (Brazil) & 3.0 & 3.0 & 2.2 & 3.0 & 3.0 & 2.2 & 3.0 & 3.0 & 2.2 & 3.0 & 3.0 & 2.2 & 3 & 3 & 2.2 \\
\hline SOMEC (Portugal) & 12.0 & 1.8 & 1.8 & 12 & 6.6 & 6.6 & 12.0 & 11.6 & 11.6 & 12.0 & 12.0 & 10.8 & 12 & 12 & 8.8 \\
\hline Total & 372.5 & 199.4 & 150.9 & 397.2 & 226.8 & 181.8 & 404.8 & 252.9 & $201: 8$ & 414.6 & 273.3 & 215.8 & 470.0 & 319.1 & 236.9 \\
\hline
\end{tabular}

Source: Bank of Cape Verde.

1/ African Development Fund; International Development Association; Arab Bank for Economic Development; African Development Bank; European Investment Bank; Organization of Petroleum Exporting Countries; International Fund for Agricultural Development; Nordic Development Fund; Nigeria Special Fund. 
Table 41. Cape Verde: External Debt Arrears by Creditors, 1993-98

(In thousands of U.S. dollars)

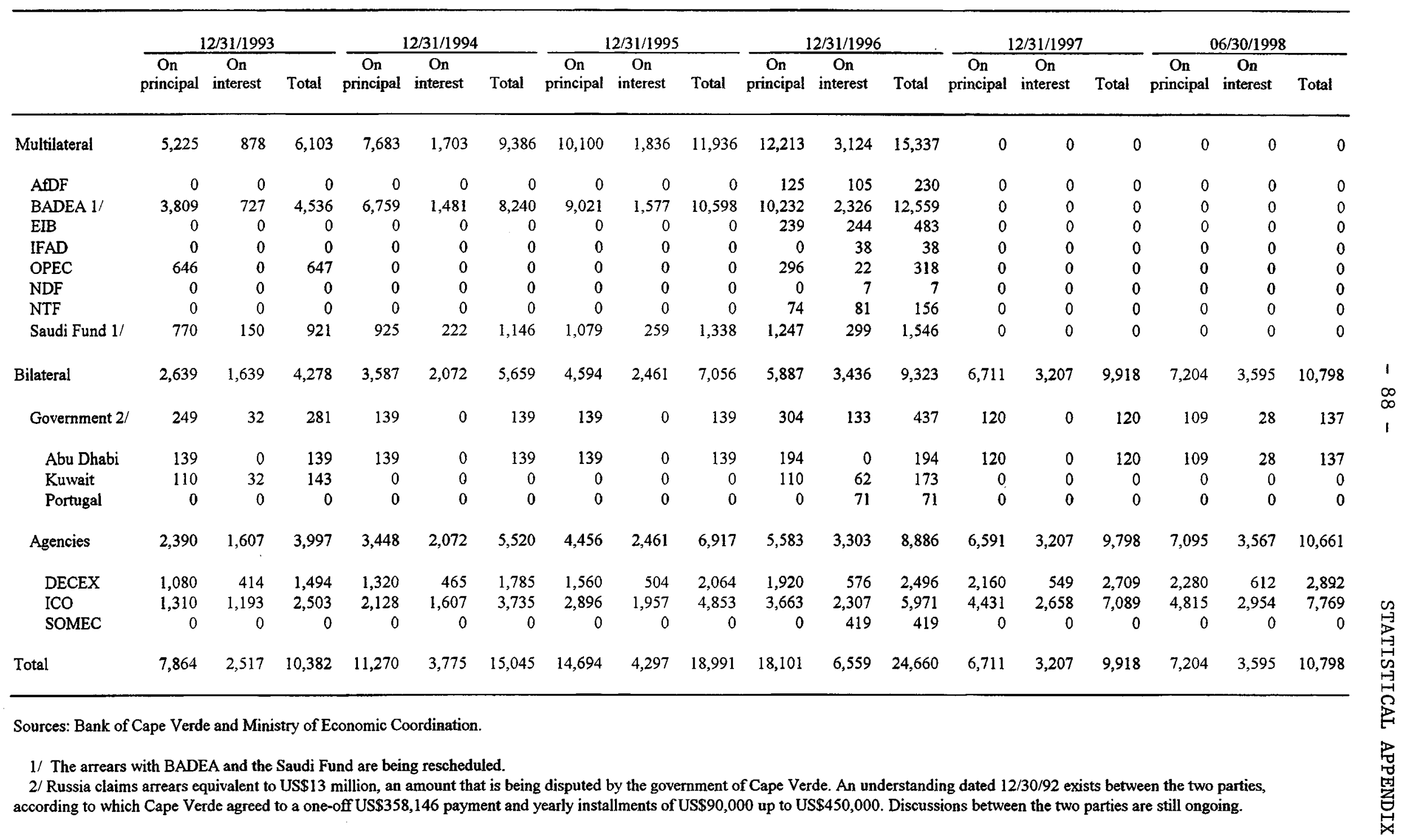

CInternational Monetary Fund. Not for Redistribution 
Table 42. Cape Verde: Medium-Term Debt-Service Projections on Outstanding External Debt, 1998-2007

(At end-1998; millions of U.S. dollars)

\begin{tabular}{|c|c|c|c|c|c|c|c|c|c|c|}
\hline & 1998 & 1999 & 2000 & 2001 & 2002 & 2003 & 2004 & 2005 & 2006 & 2007 \\
\hline $\begin{array}{l}\text { Outstanding debt } \\
\text { (beginning of period) }\end{array}$ & 236.9 & 258.0 & 297.5 & 315.0 & 316.4 & 307.8 & 293.6 & 280.0 & 267.1 & 255.5 \\
\hline Total scheduled debt service & 13.9 & 18.5 & 16.4 & 18.4 & 17.1 & 18.5 & 18.7 & 17.7 & 16.7 & 15.0 \\
\hline Amortization due & 10.2 & 14.4 & 12.0 & 13.6 & 12.2 & 13.7 & 14.2 & 13.6 & 13.0 & 11.6 \\
\hline Interest due & 3.7 & 4.1 & 4.4 & 4.8 & 4.9 & 4.8 & 4.5 & 4.1 & 3.7 & 3.4 \\
\hline
\end{tabular}

Sources: Bank of Cape Verde; and staff estimates. 
1. Single Income Tax (Imposto Único sobre Rendimentos or IUR; DecreeLaw $1 / 96$ of $1 / 15 / 96 ;$ Law $1 / V / 96$ of 6/20/96; Law $16 / V / 96$ of $12 / 30 / 96$ )

\section{Taxpayers}

- The IUR applies to the following: all national or foreign companies, whether commercial or civil in commercial form, partnerships, jointstock companies, cooperatives, public enterprises, and corporate persons under public or private law, with headquarters or actual management on Cape Verdean territory.

- Individuals engaged in import or export activities with turnover exceeding CVEsc 5 million a year.

- Unincorporated entities resident in Cape Verde (e.g., unsettled estates, legal entities declared invalid, unincorporated civil companies, commercial companies, or civil companies in commercial form).

- Individuals or corporations not resident in Cape Verde, as long as they produce or earn any income in Cape Verde.

\section{Exemptions}

- The state, municipalities, and any of their services or establishments are exempt, even if identified as individual taxpayers, provided that they do not engage in commercial, industrial,

agxicultural, fishing, or service providing activities.

- Social welfare institutions and labor unions or associations are exempt regarding the activities for which they were legally established and provided that they do not engage in commercial, industrial, agricultural, service providing, or capital investment activities.

- The Bank of Cape Verde is exempt from payment on the income earned from operations that it carries out as General Cashier of the Treasury and related activities.

- Also exempt are associations legally established to perform cultural, recreational, or sporting activities and which meet all the following conditions: there are no distributed profits; and no member of their corporate bodies has a direct or indirect interest in their operating profit.

- Interest from emigrants' term deposits is exempt.
- The following rates apply: 20 percent for enterprises subject to preassessment; 35 percent for enterprises subject to direct assessment; 20 percent on interest from term deposits; 15 percent on other capital income (dividends, profit sharing, and advances on profits); and 20 percent on profits earned by nonresidents (on billing volume).

Note: The rates will be published in the State Budget Law. 
Table 43. Cape Verde: Summary of the Tax System (As of end-1998)

- The income of (a legally established) agncultural, fishıng, housing

education, or handicraft production cooperatives is exempt, provided that at

least three-fourths of its workers are members and none owns more than 10 percent of the cooperative's equity capital, and that turnover does not exceed CVEsc 10 million

- Fishing, artisanal, or industral activities are exempt provided that annual turnover does not exceed C V Esc 3 million

- Income from treasury securties is exempt

\section{Personal Tax Base}

- Insofar as it applies to individual income, the IUR is chargeable on overall annual income in the

following categones

- Category A comprises income from property,

- Category B cor ers commercial and industrial income, including capital gains, provision of services, and agnicultural and fishing income,

- Category $\mathbf{C}$ constitutes capital income and other moome such as that from gaming, lotteries, and mutual betting, and income of CVEsc 150,000 or less

- Staff of diplomatic or consular missions,

- Foreign staff of foreign organizations,

- Clencs, when exercising therr spiritual mission,

- Salartes or other income patd to employees and workers on leave for treatment abroad,

- Family allowances granted under law,

- Cost allowances up to the limits set by law,

UR Withholding Schedule (Individuals)

Annual income brackets

(In Cape Verde escudos)

Up to 150,000

Up to 300,000

Up to 630,000

Up to $1,260,000$

Up to $1,890,000$

Over $1,890,000$
Rates

(In percent) 
- Category D comprises wage and salary income, including reserve and retirement pensions, alimony, and fixed-term, life, or other kinds of annuities.

\section{Assessment methods}

Three assessment methods are used:

- Under self-assessment (método declarativo), a return is submitted by the taxpayer or, in cases of tax substitution, by the entity legally required to do so;

- Preassessment (método de estimativa) is applied to all individuals not considered to be companies for tax purposes as envisioned in the industry schedule (Tabela Geral das Indústrias). The taxable base is determined on a presumptive basis, taking into account the turnover and kind of business, or normal production and market conditions if returns are not filed.

- Under direct assessment (método de verificação), the taxable base is based on the taxpayer's filed return, which derives from the accounting data.

The tax due in accordance with these methods is paid in two installments.
- Cash shortage allowances up to 10 percent of monthly salary;

- Occasional medical or hospital allowances; and retirement pensions up to CVEsc 960,000 a year.

- Severance payments arising from contract rescission or extinction of public employment, if agreed between the employer and the worker.

\section{Deductions}

The following deductions apply: up to CVEsc 132,000 for single, widowed, or divorced individuals; CVEsc 180,000 for single-income married couples;

CVEsc 300,000 for married couples with two or more incomes; CVEsc 80,000 for individuals resident abroad; CVEsc 25,000 for each child, up to a maximum of CVEsc 100,000; and 80 percent of receipts from housing rental, up to a maximum of CVEsc 144,000.

Also deductible are interest and charges on home purchase or improvement loans, up to a maximum of CVEsc 144,000 ;

pension allowances that the taxpayer is required to pay, up to a maximum of

CVEsc 240,$000 ; 40$ percent of income from liberal professions, up to a maximum of CVEsc 80,000; mandatory social

\section{IUR Annual Calculation Schedule (Individuals)}

Overall annual income
In Cape Verde escudos

$\begin{array}{cc}\text { Marginal } & \text { Average } \\ \text { Rate } & \text { Rate }\end{array}$

Up to 300,000

Up to 630,000

Up tp $1,260,000$

Up to $1,890,000$

Over $1,890,000$

(In Percent)

15.0

15.0

$20.0 \quad 17.9$

$27.5 \quad 21.0$

$35.0 \quad 29.2$

$\begin{array}{ll}35.0 & 45.0\end{array}$ 
security or union contributions paid by

industrial or commercial workers; life,

health, or accident insurance premiums, up

to a maximum of CVEsc 30,000; grants to

schools, homes for the aged and child care

centers, up to a maximum of

CVEsc 240,000.

50 percent of health expenses,

CVEsc 50,000 every two years for

purchase of computer equipment, and

interest on loans for payment of health

expenditures are deductible.

Wages and salaries subject to IUR; rents subject to real estate tax; fees paid to perform any activity; contributions to unions and union funds; insurance

premiums and trade association fees.

10 percent abatement of tax payable by eligible companies that used Cape Verdean merchant ships to carry at least 50 percent of their imports during the base year; and

an amount equal to the discount rate plus 2 percent applied to tax obligations settled advance.

2. Tax on Petroleum Products

(Imposto sobre Produtos Petrolífero; Law $61 / \pi V / 92$ of $12 / 30 / 92$; Law $95 /$ IV/93 of 12/31/93).

\section{Taxpayers}

Individuals or corporations legally authorized to import fuel.

\section{Tax base}

Levied on gasoline and diesel fuel

consumption in land transport within the country.
A rate of CVEsc 10 per liter is applied to gasoline; a rate of CVEsc 5 per liter is applied to diesel fuel. 
This tax is not taken into account in the calculation of the profit margin, but it is included in the retail price.

3. Real Estate Tax (Law 1543/63, amended by Law $61 / \mathrm{TV} / 92$ of $12 / 30 / 92$; and Law $94 / \mathrm{IV} / 93$ of $12 / 31 / 93$; and Law $79 / V / 98$ of 12/7/98).
Charged on rural and urban property, whether rented or owner occupied. It is based on the rent charged or on the annual rental value established by the permanent valuation committee. The tax due is paid in one or two equal installments.

\section{Exemptions}

The following are exempt: government buildings, including those occupied by

economic coordination agencies; buildings belonging to local and administrative institutions that do not produce rent or ground rent; buildings occupied by

hospitals, shelters, or other social welfare institutions; buildings used for religious services; public interest institutions; rentexempt schools; facilities of sports associations; diplomatic or consular buildings; private secondary school buildings worth more than C.V. Esc 1 million if situated in Praia or Mindelo or those worth more than CVEsc 500,000 elsewhere in the country, for 15 years; finished buildings, for 6 years (rental) or 10 years (owner occupied), from the completion of construction; nonproductive rural properties; rural properties used for certain crops, for 10-20 years from the start of cultivation; rural buildings with yearly rent below CVEsc 5,000 and urban buildings with yearly rent below CVEsc 100,000 .
A rate of 3 percent is applied to the value of both rural and urban buildings. 
Table 43. Cape Verde: Summary of the Tax System (As of end-1998)

\section{Deductions}

For urban properties, 15 percent of rental value is deductible as maintenance expense.

For rural properties, normal expenses with cultivation, maintenance, and sale of products. Also deductible are improvements to rural buildings, construction of and improvements to rural buildings, administration, fertilizer, seeds, wages, and some inputs. Taxable income shall be no less than 40 percent of the gross income obtained from agricultural activity. 
Table 43. Cape Verde: Summary of the Tax System

(As of end-1998)

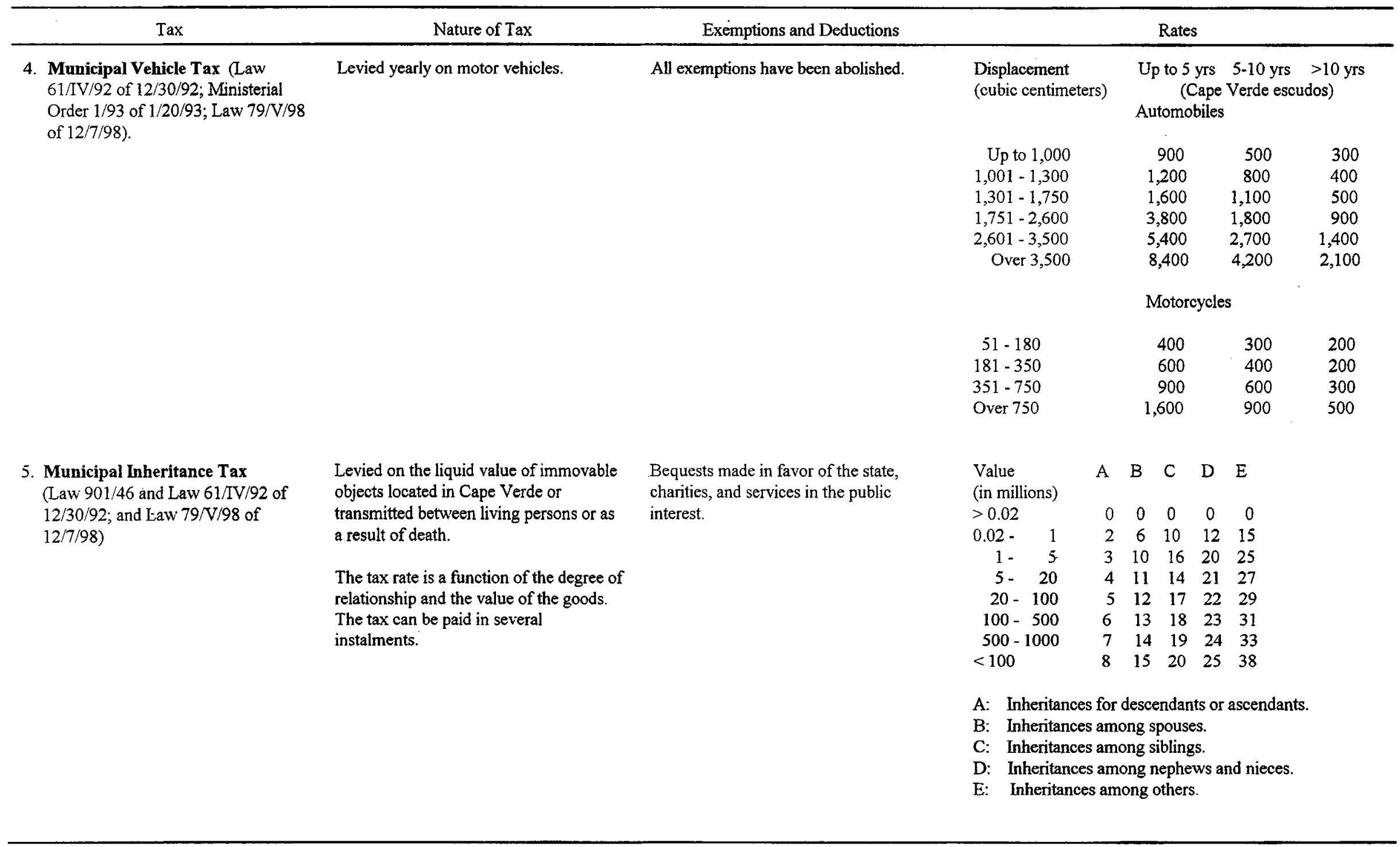

